\title{
المحل في عقد الصلح الإداري: دراسة مقارنة
}

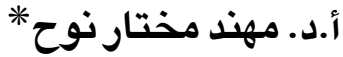

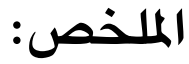

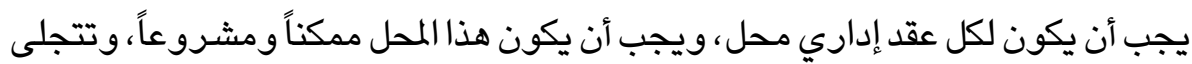

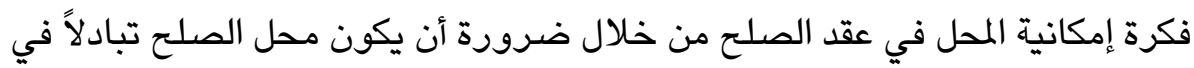

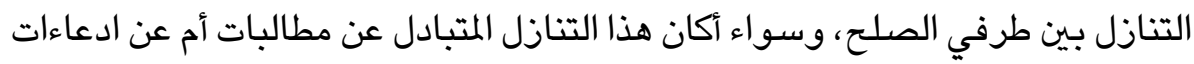

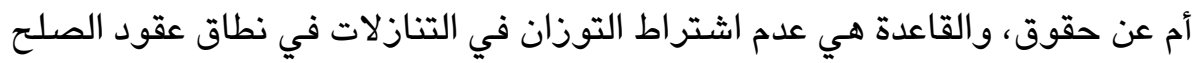

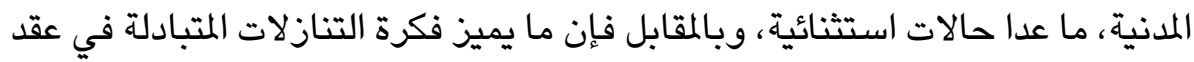

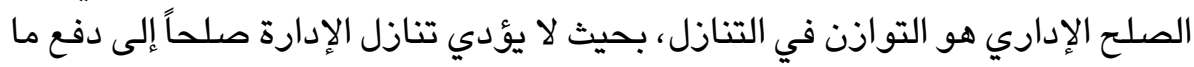

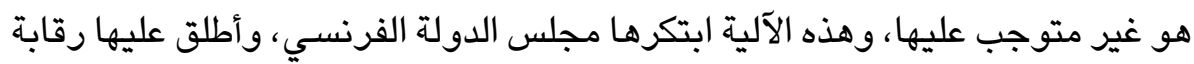

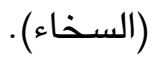

وتتجلى مشرو عية المحل في عقود الصلح الإدارية في كون بعض المسائل لا تصلح محلاً

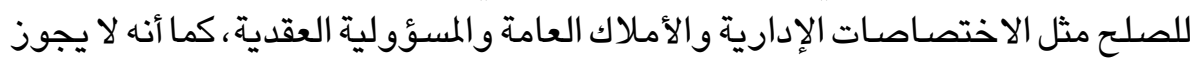

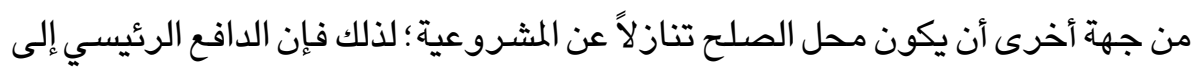

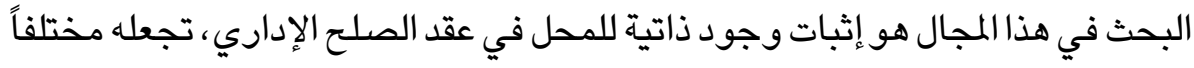

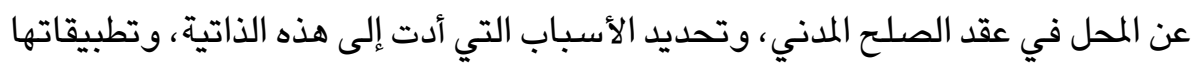

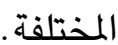

وقد تم تناول البحث في محورين بحيث تم التطرق في أولهما إلى فكرة وجود المحل في

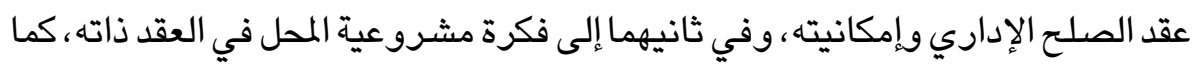

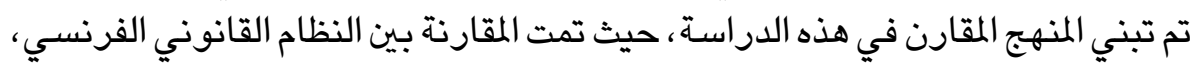

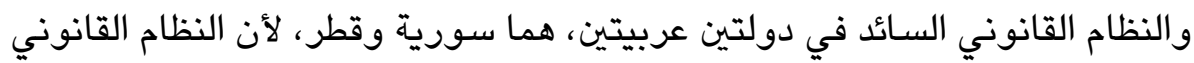

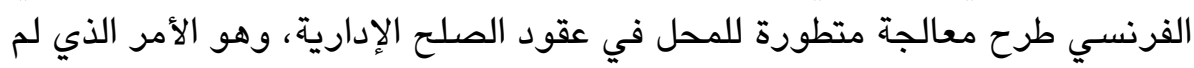

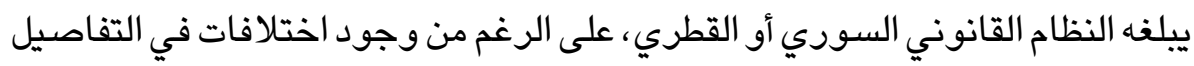
بينهما. وأهم ما تم التوصل إليه في هذا البحث هو عدم وجود رقابة قضائية فعالة في كل من

* * أستاذ القانون العام، كلية القانون، جامعة قطر. 


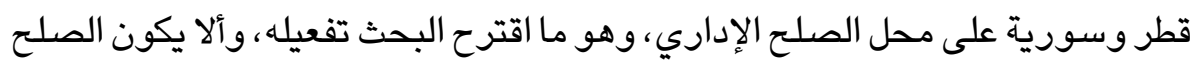

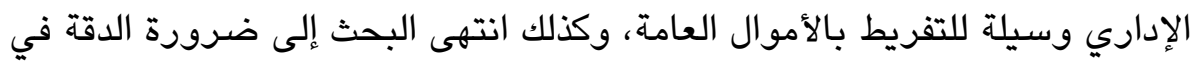

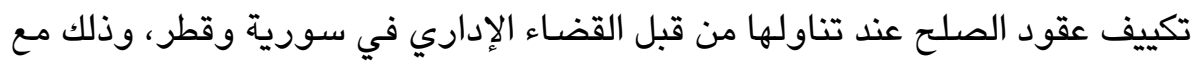

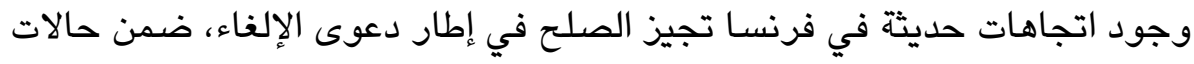

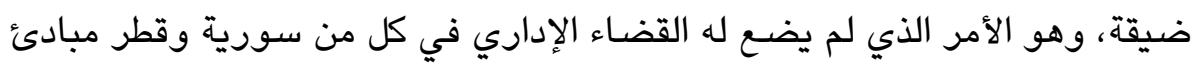
واضحة. كلمات دالة: العقد الإداري، التنازلات المتبادلة، القضاء الإداري، حل المنازعات، الأموال العامة. 


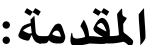

يُعرَّف الصلح بأنه : (وسيلة تعاقدية لإنهاء نزاع قائم أو محتمل عن طريق تقديم تنازلات

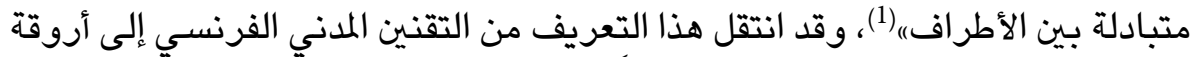

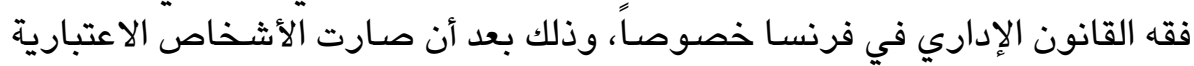

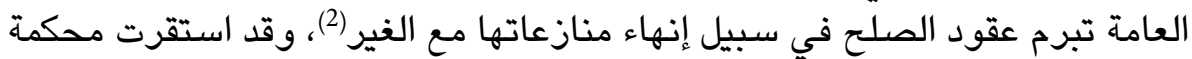

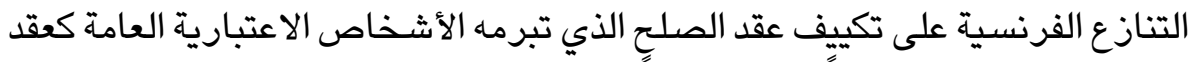

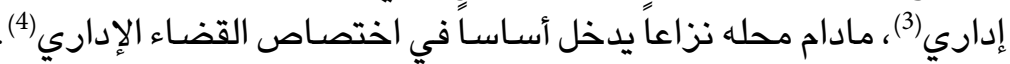

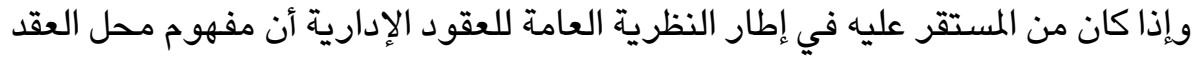
L'objet du contrat

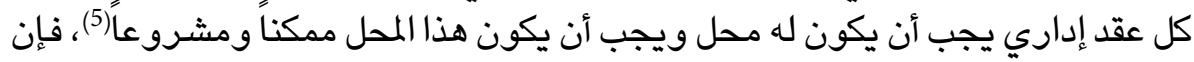

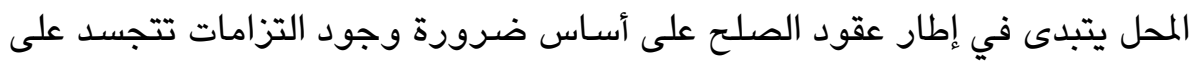

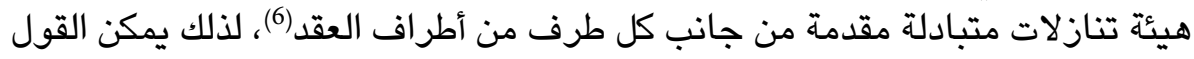

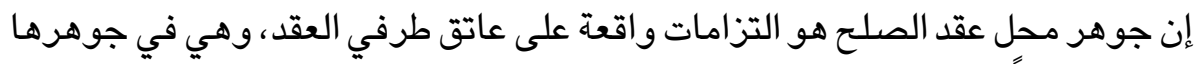

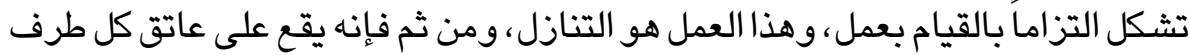

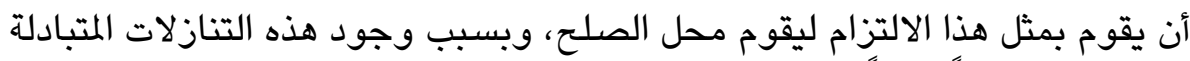

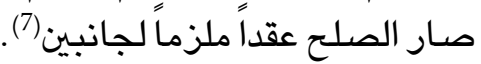

وإذا كان العقد الإداري يقوم على ذات الأساس الذي يقوم عليه العقد المدني بالنسبة

(1) Guettier Ch., Droit des contrats administratifs, P.U.F, Paris, 2011, p.505.

(2) Roux. E., Panorama des différents modes alternatifs de règlement des litiges, AJ Collectivités Territoriales, 2012, p.236.

(3) Melleray F., La répartition des compétences juridictionnelles en matière de transactions conclues par une personne publique, Droit Administratif, Novembre, 2007, n 11, comm. 156.

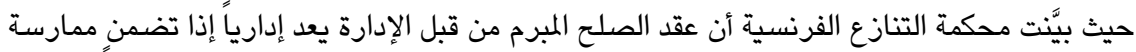

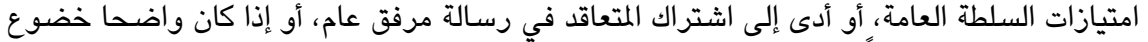

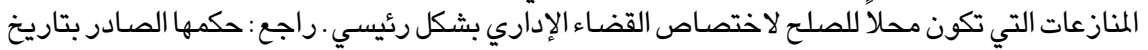

2007/6/18، في قضية Sté Briançon Bus et M.B -c- Che Briançon، والمنشور في 2007، AJDA ، ص 210 ، 210.

(5) Guettier.CH., op. cit., p.3̈53.

وباللفة العربية راجع: د. سليمان الطماوي، الأسس العامة في العقود الإدارية، مطبعة جامعة عين

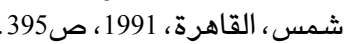

(6) Chauvel. P., Transaction, Répertoire de droit civil, septembre 2011 (actualité: mars 2014), n41 et.s. وباللغة العربية: د. عبد الرزاق السنهوري، الوسيط في شرح القانون المدني، الجزء الخامس، باقي

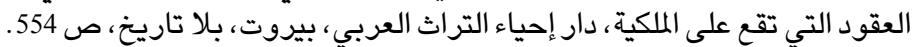

(7) Noury. A., Les modes alternatives au règlement par les juridictions étatiques des litiges intéressant l'administration, C.R.A.P.S, Université lille2, Paris, 2001, p.72. 


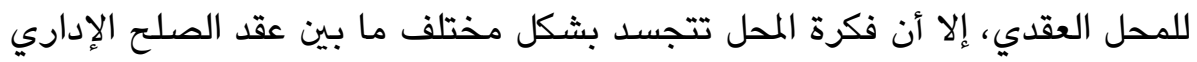

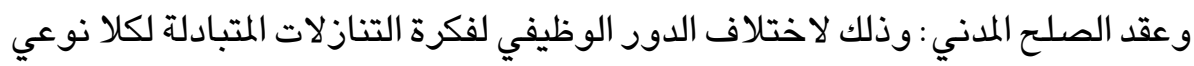

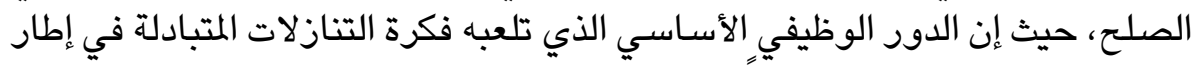

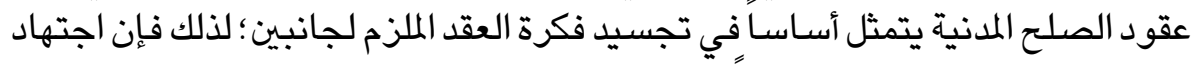

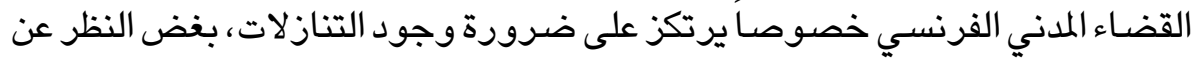

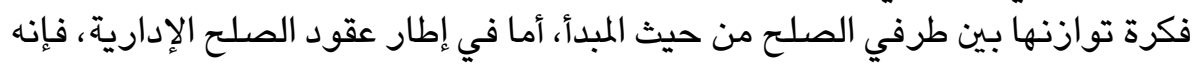

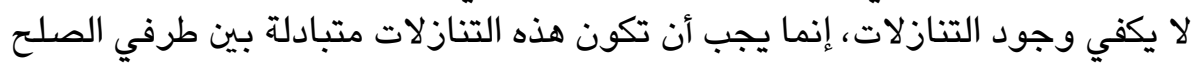

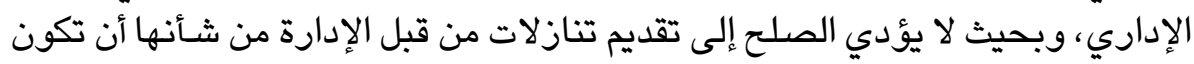

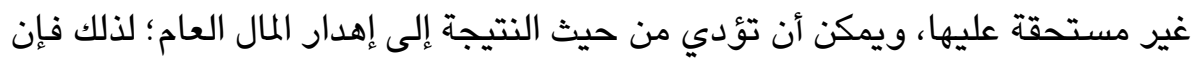

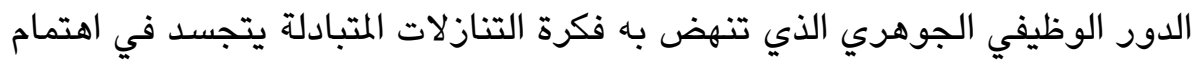

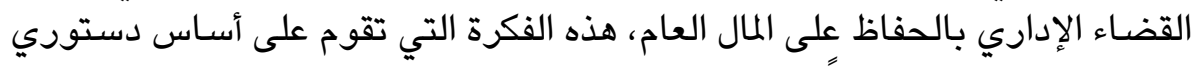

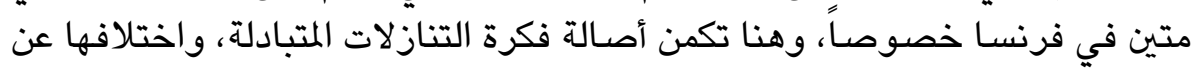
الفكرة المتجسدة في فرنسا فمسودار عقود الصلح المدنية.

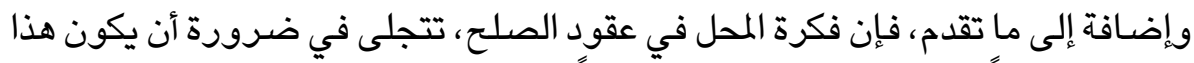

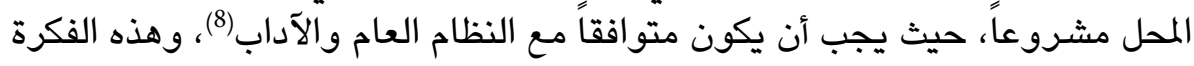

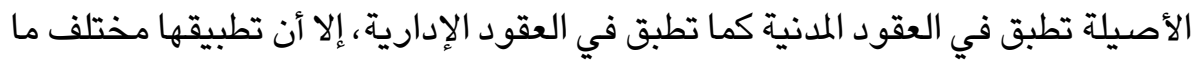

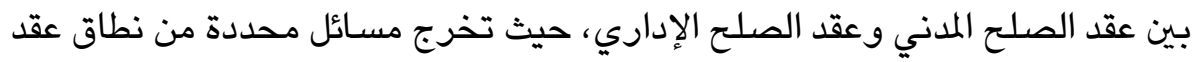

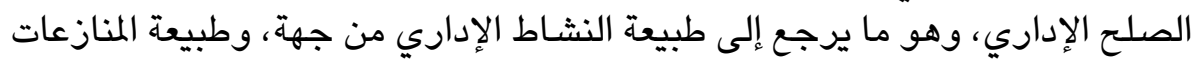

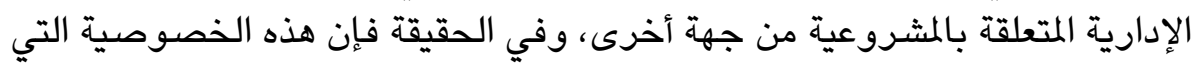

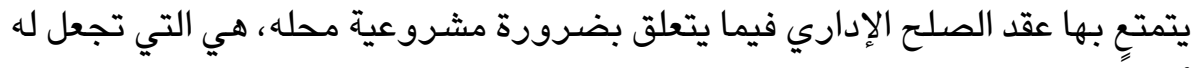
أيضـاً ذاتية مستقلة من حيث المحل في مواجهة عقود الصلّح المدنية. وبذلك، فإن هذا البحث يهدف إلى الإجابة على الأسئة التالية :

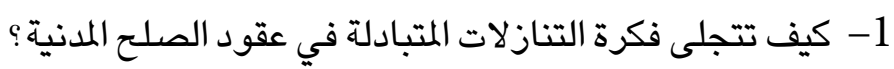

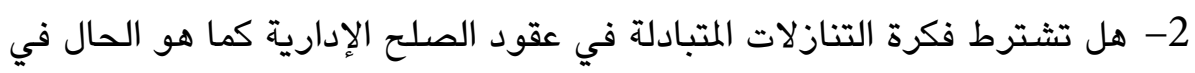

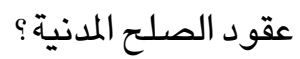
3- هل تتمتع فكرة التنازلات المتبادلة بذاتية مستقلة عن نظيرتها في عقود الصلح

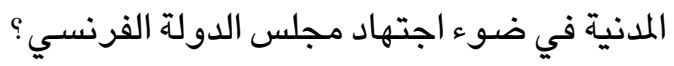
4- وإذا تمت الإجابة على السؤال السابق بالإيجاب، فهل طبق القضـاء الإداري السوري (8) Guettier.CH., op. cit., p.353. 
والقطري فكرة التنازلات المتبادلة على أسـاس الأخذ بالحسبان لهذه الذاتية المستقلة و

5- كيف تتجلى فكرة مشروعية المحل في عقود الصلح الإدارية ؟ وهل هناك ذاتية

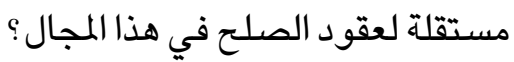

6- كيف تتجلى فكرة المحل في عقود الصلح الإدارية في النظام القانوني السائد في سورية وقطر ؟

وسوف نبحث ذلك في نطاق المنهج المقارن بين ثلاثة نظم قانونية، النظام القانوني

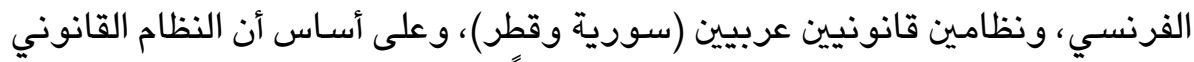

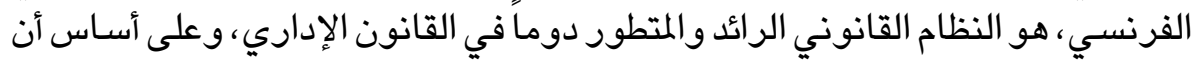

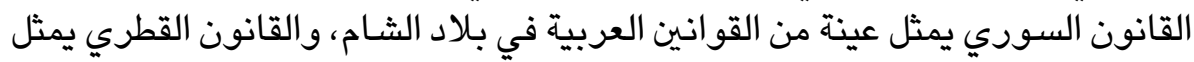
عينة من القوانين العربية في الخليج العربي.

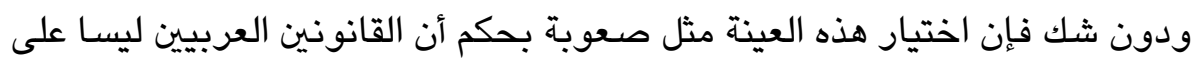

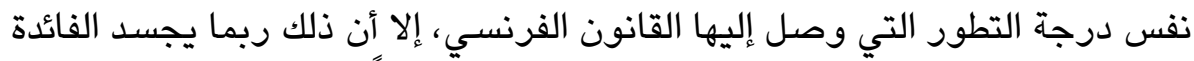

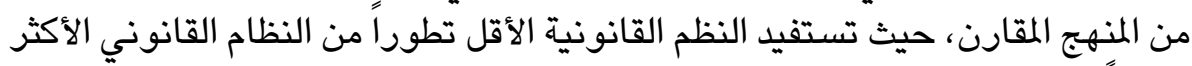
تطوراً، ولاسيما في إطار سد الفراغات الاجتهادية والتشريعية.

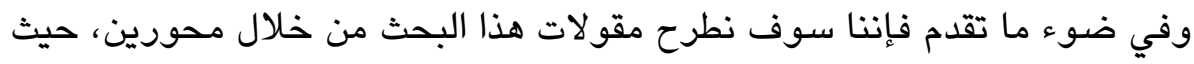

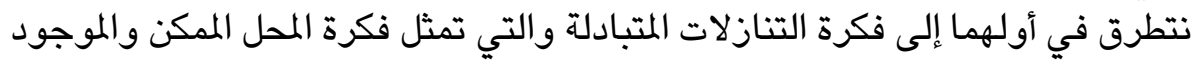

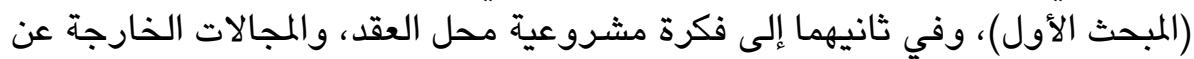
إطار عقود الصلح الإدارية (المبحث الثاني). 


\section{المبحث الأول \\ المحل الموجود والممكن: فكرة التنازلات المتبادلة}

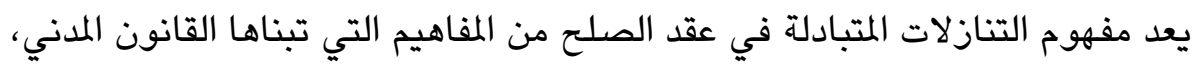

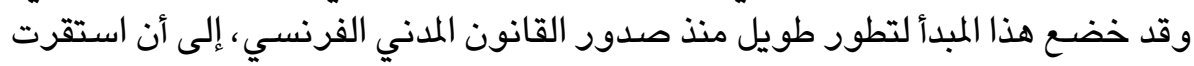

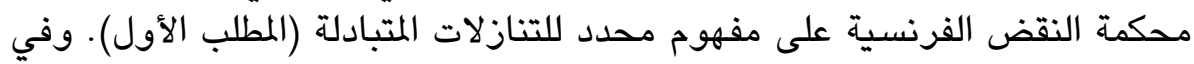

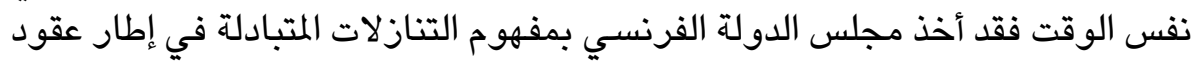

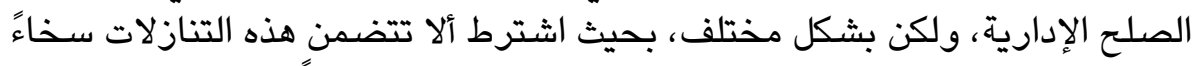

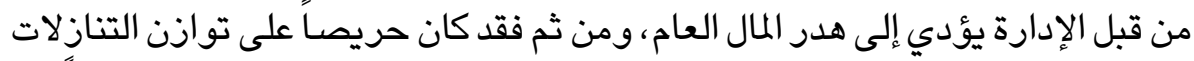

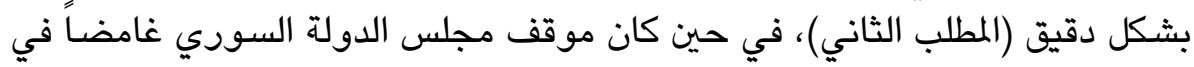

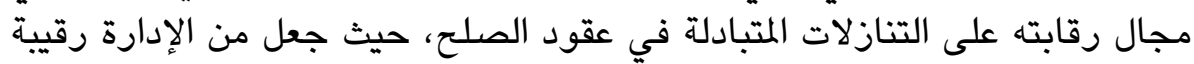

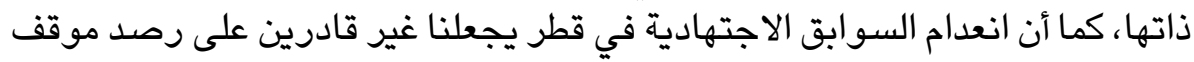

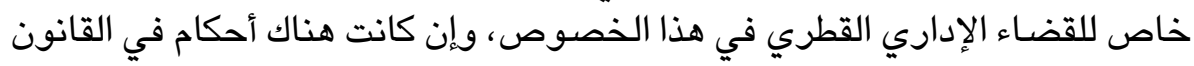

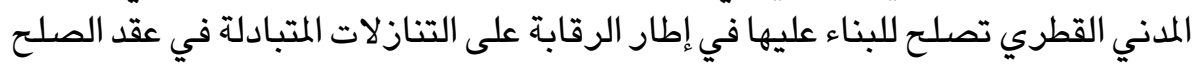

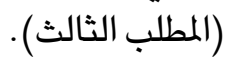

\section{المطلب الأول}

\section{تطور مفهوم التنازلات المتبـادلة في إطار عقد الصلح المدني}

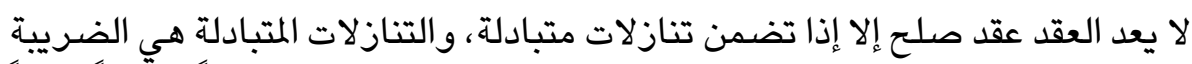

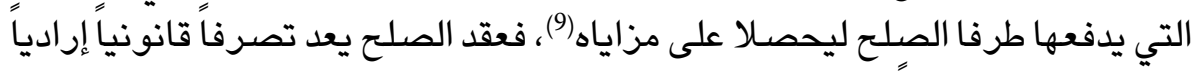
ومتوازناً Volontaire

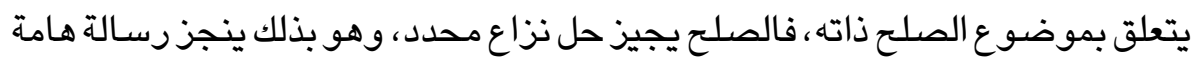

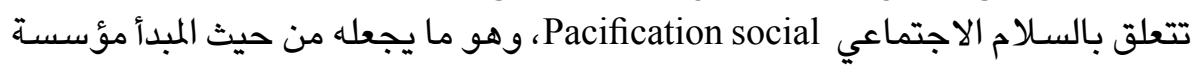

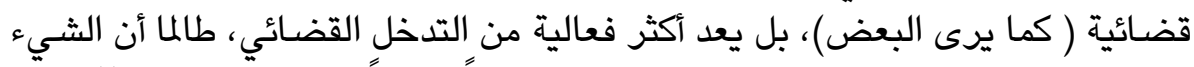

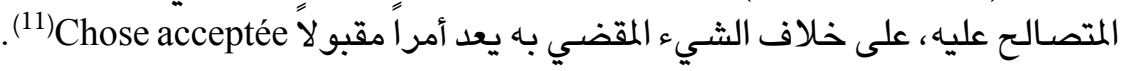

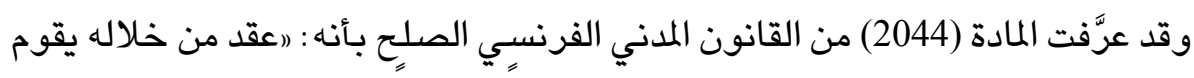

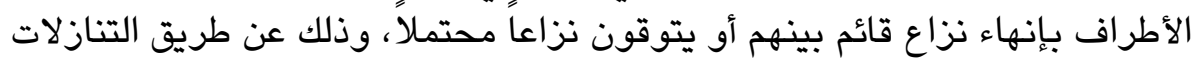

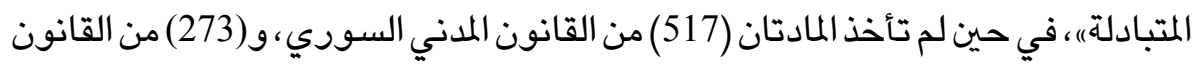

(9) Rayssac R., La transaction en matière administrative, Thèse, université de Tour, France, 1999, p.25.

(10) Lagard X., Transaction et ordre public, D, 2000, Chron, p.218.

(11) Lagard X., Ibid, p.218. 


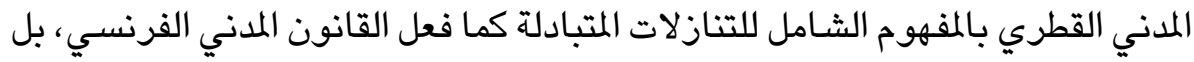

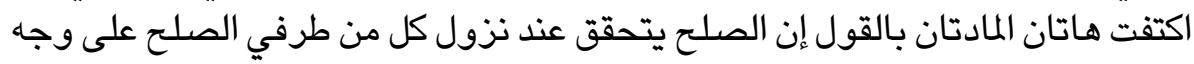
التقابل عن جزء من ادعائه.

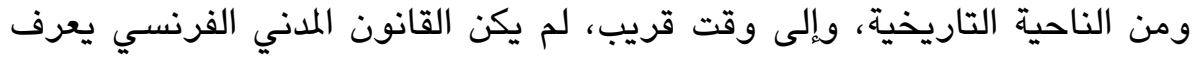

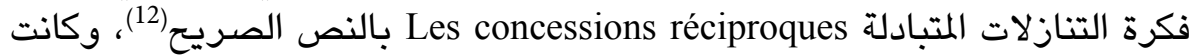

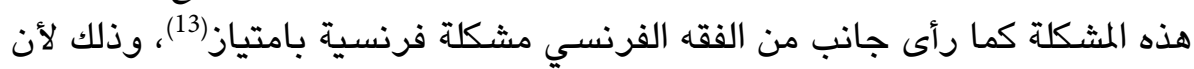

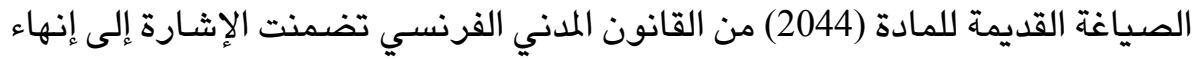
النزاع عن طريق الصلح، دون أن تبين الوسائل الضرورية للوني الوصول إلى الى ذلك، والمتمثلة في التناز لات المتبادلة(14).

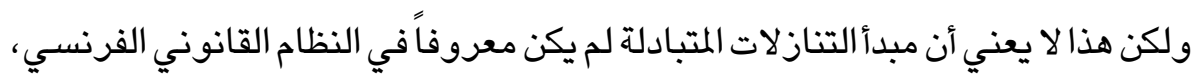

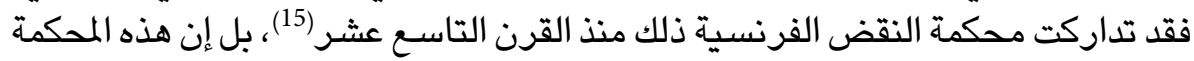

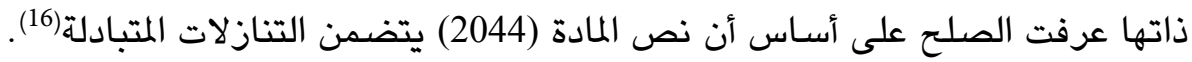

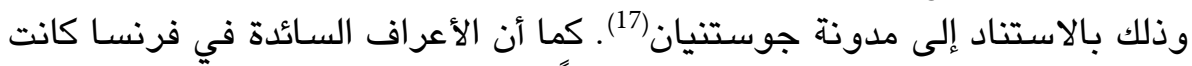
تشترط التنازلات المتبادلة ليقوم الصلّح قدانوناً (18).

(12) Cornu. J., La transaction en matière administrative, mémoire, Master recherche, Droit public approfondi, Université Paris II, 2007, p.15.

(13) Jarrosson CH., Les concessions réciproques dans la transaction, 1997 D., p.271.

(14) على الرغم من أن تقنين جوستيان نص في المادة (38) منه على ما يلي : رلا يمكن أن يوجد الصلّح دون

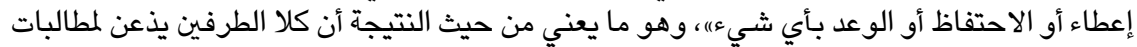

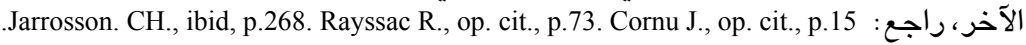

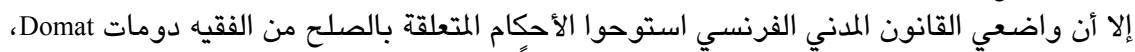

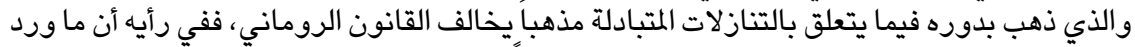

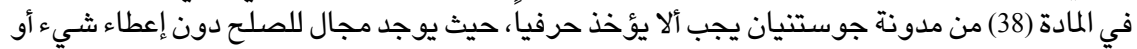

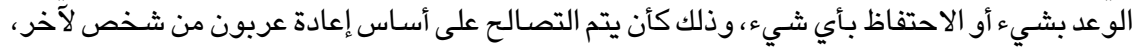

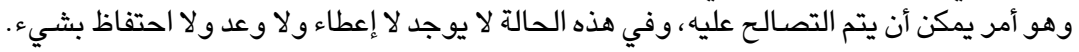
Jarrosson CH., op. cit., p.269. Fourcade C., La transaction en droit du travail: quelle place pour la liberté contractuelle? R.D.S, 2007, p.166.

(15) Cass. Civ., 3-11883, DP,1883,1, Jur., p.475 Cité par Jarrosson CH., op. cit., note 25.

(16) Cass. Soc.13.11.1959, J.C.P,1960, II, n¹1450, note Camerlynck G.H.

وقد كان دافع محكمة النقض الفرنسية إلى ذلك تمييز الصلح عن غيره من المفاهيم الأخرى التي قد تختلط

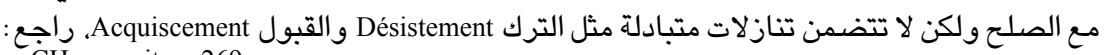
Jarrosson $\dot{\mathrm{C}} \mathrm{H}$., op. cit., p.269.

(17) Chavrier G., Réflexions sur la transaction administrative, RFDA, 2000, p.565.

(18) وعلى ذلك، وكما يرى جانب من الفقه الفرنسي أن واضعي القانون الملدي الفرنسي لم تتجه إرادتهم

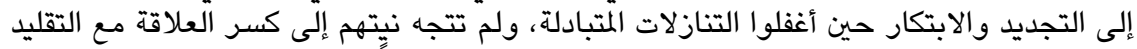

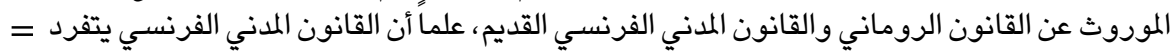


وقد تدخل المشـر ع الفرنسي مؤخراً، وعدل من نص المادة (2044) سـالفة الذكر ، وأضساف

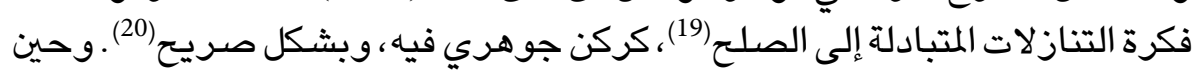

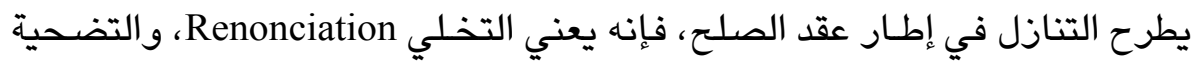
Le sacrifice رغبتهم بإنهاء النزاع(21)، ولكن لا يقتصر الأمر على ذلك، حيث يمكن أن يكتسي التنازل

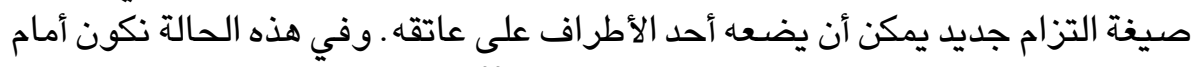

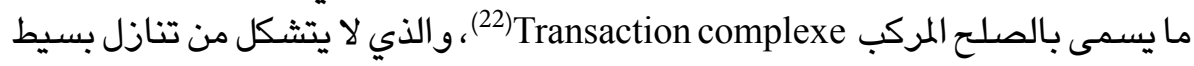

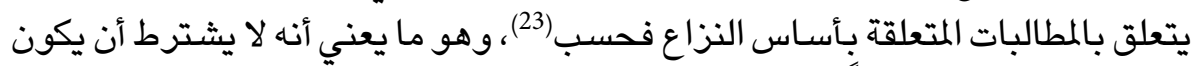

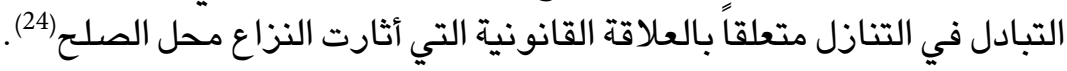
ولكن السؤال الذي يطرح نفسـه هو ذلك المتعلق بماهية التخلي، وبمعنى آخر إذا كان

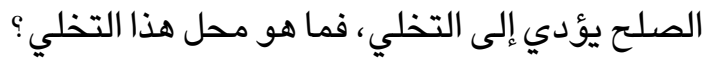

في الحقيقة يتم التخلي عن المطالبات Les prétentions، والمطالبات هي مجموع كل ما يراه كل طرف أنه حق له، وهو ما يعني أنه لا يتم التنازل عن حقوق فعلية عند إبرام عقود

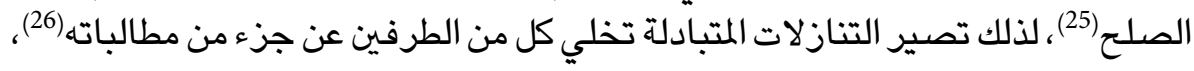

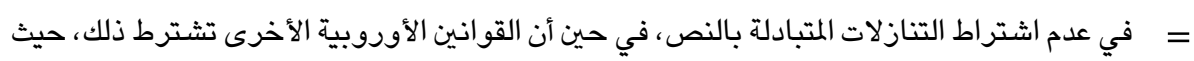

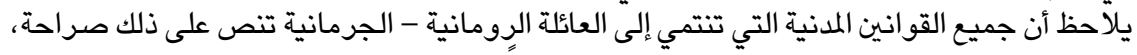

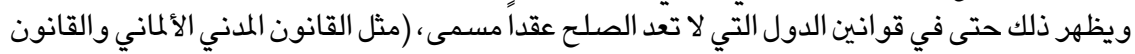

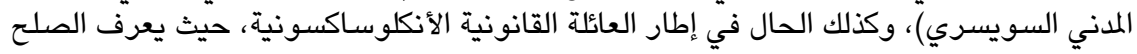
Compromise السوابق القضائية في بريطانيا تشترط ذلك.

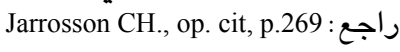

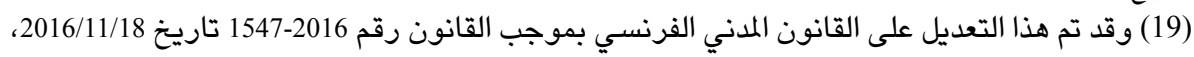

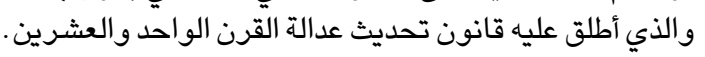

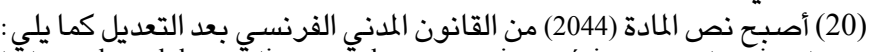
«La transaction est un contrăt par lequel les părties ,par des concessions réciproques ,terminent une contestation née ,ou préviennent une contestation à naître .Ce contrat doit être rédigé par écrit.»

(21) Mayer L., La transaction, un contrat spécial? RTDC, 2014, p.526.

(22) Mayer L., Ibid, p.526.

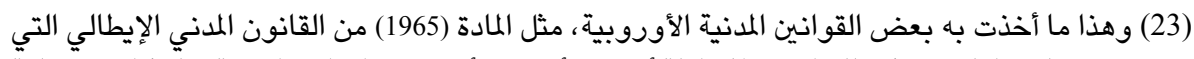

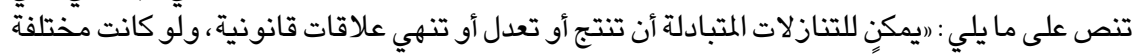

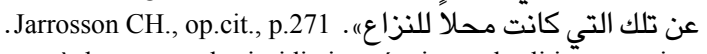

(24) Noury A., Les modes alternatives au règlement par les juridictions étatiques des litiges, op.cit., p.73. (25) وهو ما قررته محكمة النقض الفرنسية بقولها : "يجب أن يقدر وجود التنازلات المتبادلة حسب مطالبات

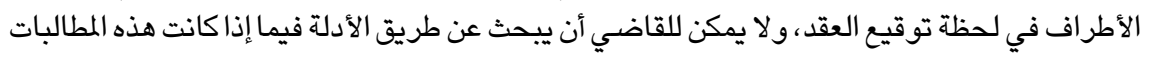
(26) Lagard X., op.cit., p.218.

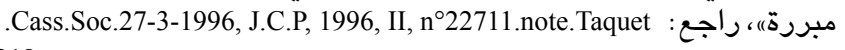




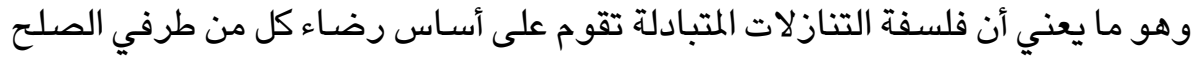

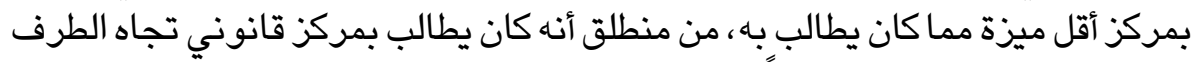

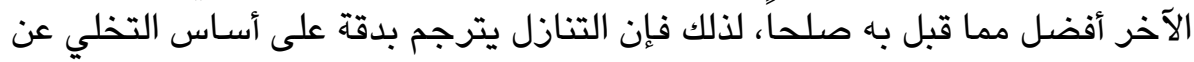

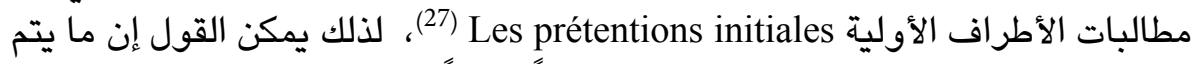

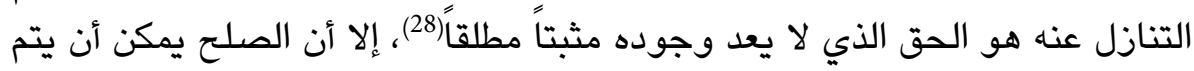

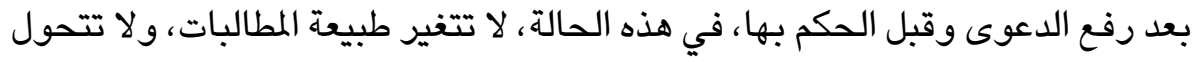

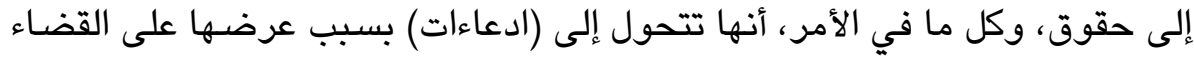

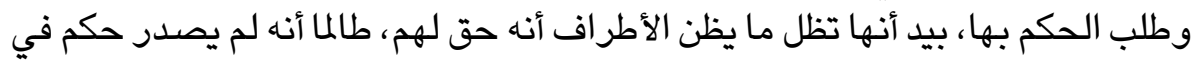

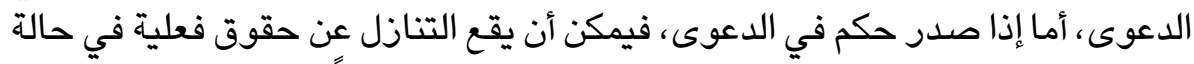

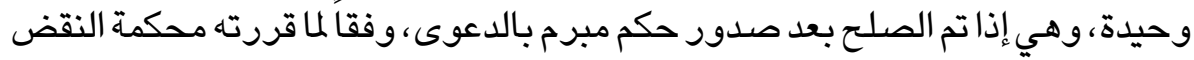

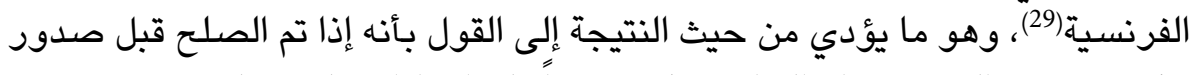

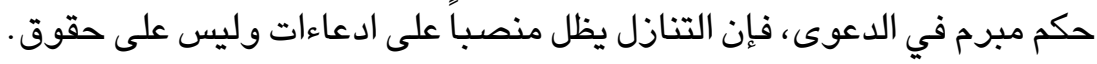
إن الطرح السابق يفرض ضرورة مناقشَّة ما ورد في المادة (517) من القانون المدني

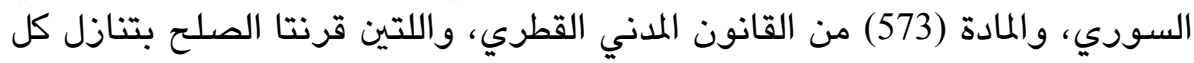

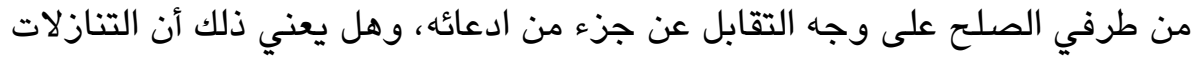

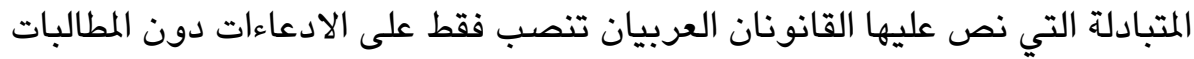

$$
\text { والحقوق؟ المتبادلة }
$$

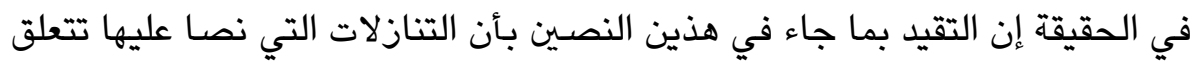

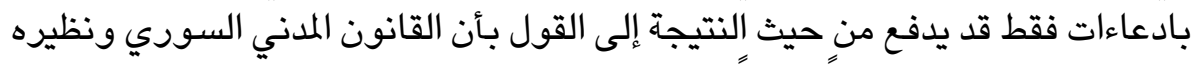

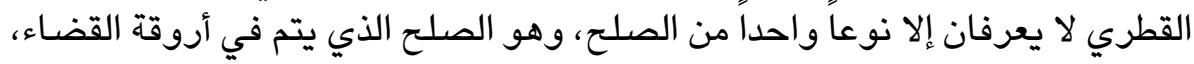

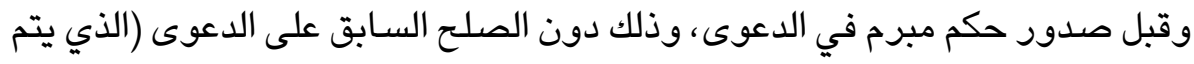

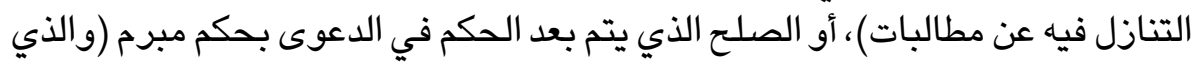

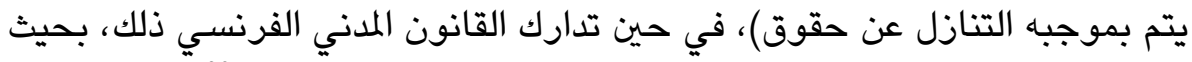

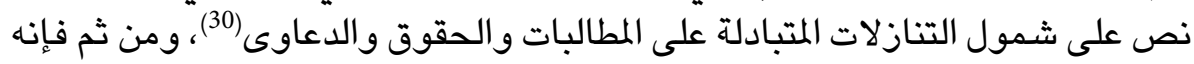

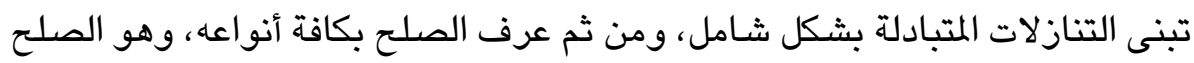

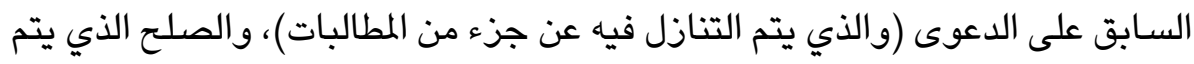

(27) Mayer L., op.cit., p.523.

(28) Lagard X., Ibid. p. 218.

(29) Cass.12-11-1902, S, 1905, Jur., p.14.

(30) تتص المادة (2048) من القانون المدني الفرنسي على ما يلي : «Les transactions se renferment dans leur öbjet: la reñonciation qui y est faite à tous droits, actions et prétentions...». 
أمام القضاء (الذي يتم التنازل فيه عن جزء من الادعاءات)، والصلح الذي يتم بعد صدور

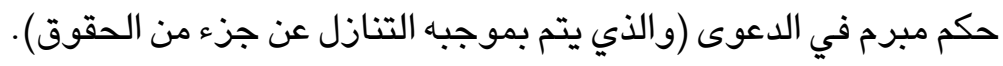

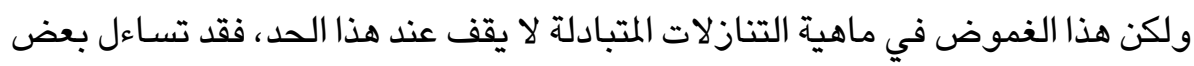

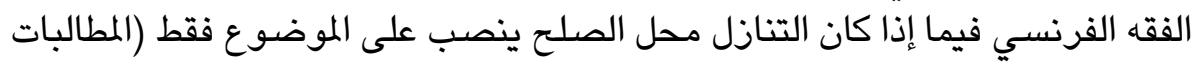

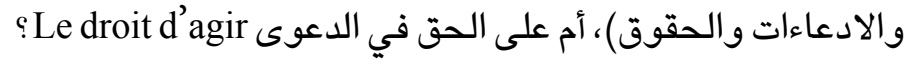

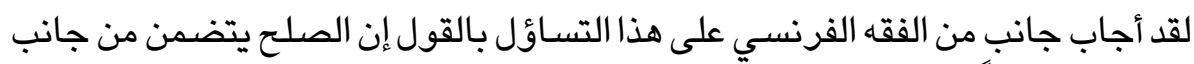

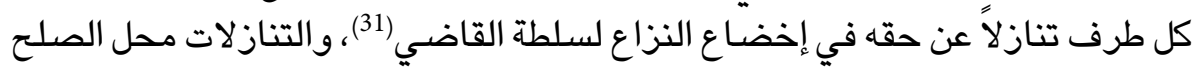

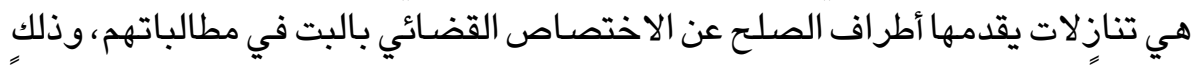

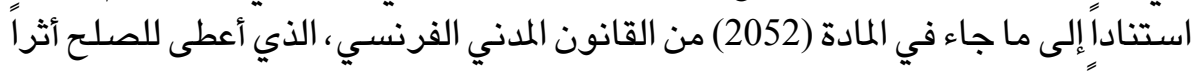

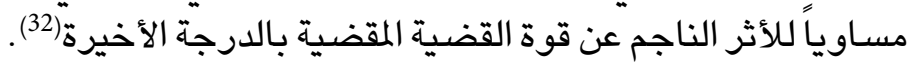

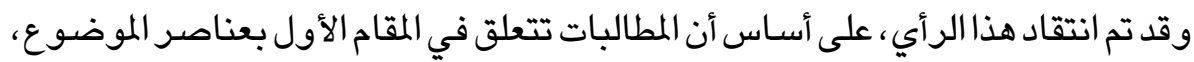

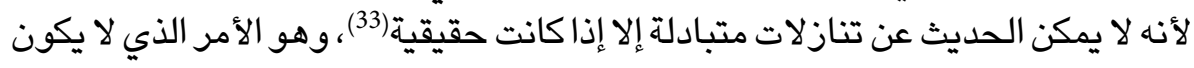
إلا إذا نجم عنها تضحيات حقيقية من جانب كل طرف الإن وعلى إنى أن تكون قابلة للتقدير (34)،

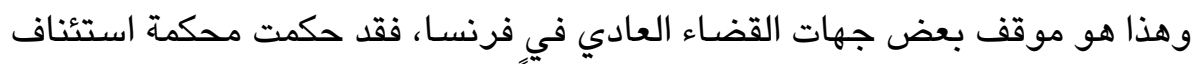

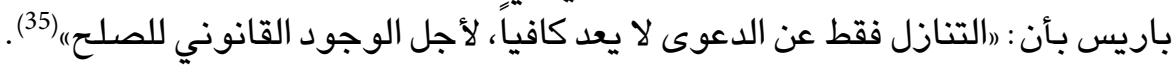

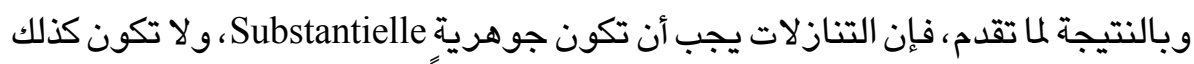

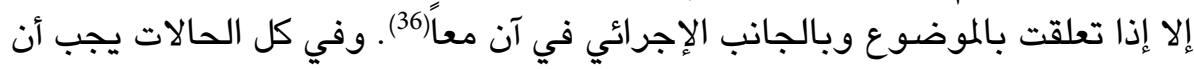

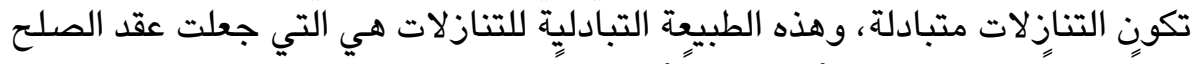

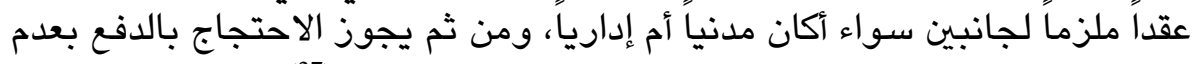

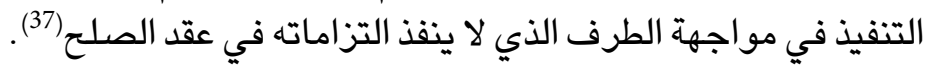

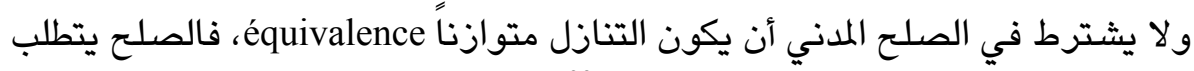

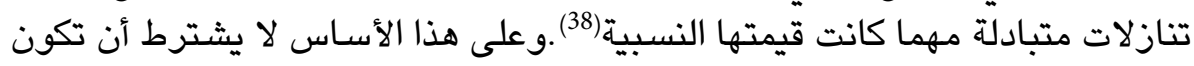

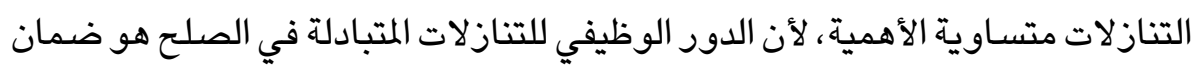

(31) Lagard X., op.cit., p.225.

(32) Jarrosson CH., op.cit., p.273.

(33) Fourcade C., op.cit., p.167.

(34) Jarrosson CH., Ibid, p.273. Lagard X, op.cit., p.225. Chavrier G., op.cit., p.554.

(35) C.A, Paris, 11-6-1975, J.C.P, 1976, II,n ${ }^{\circ} 18357$. Note.Y.Assouline

(36) Cornu J., op.cit., p.31.

(37) Jarrosson, CH., op.cit., p.274.

(38) Cass. Soc.13-5-1992, Bull.civ.n³07, R.T.D.C, 1992, P783, obs. Gautier P.Y.

وراجع في الفقه Cornu J., op.cit., p.30 
حد أدنى من العدالة، لذلك يجب أن توجد هذه التنازلات ليكون العقد صلحاً، وإن لم تكن متسـاوية(39)، ويستقل قضناة الموضوع في تقدير وجود هذه التنازلات من عدمه(40)،

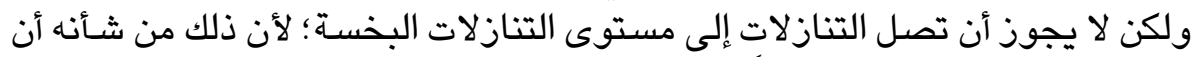

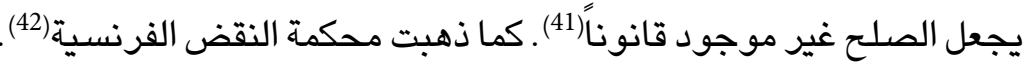

وفي مجمل الأحوال، فإن بعضـاً من الفقه الفرنسي يرى بحق أن عدم التدقيق في الرقابة

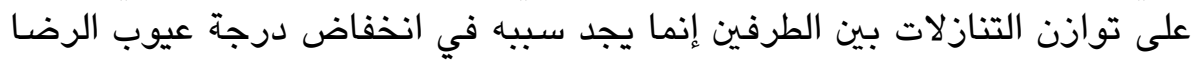

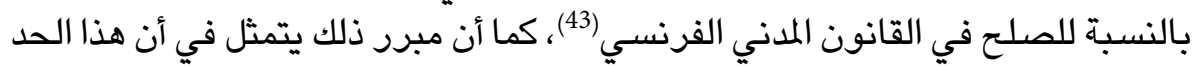
المنخفض للرقابة على توازن التنازلات يتمثل في أن الحالة الشـائعة في عقود الصلِِّ هي أن يتم التخلي عن مطالبات وليس عن حقوق، وإن تقدير المطالبات لا يكون ممكناً لأنه

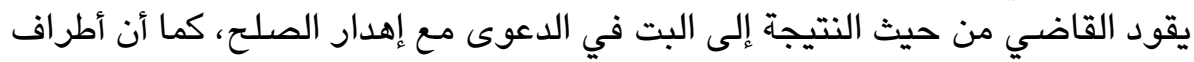

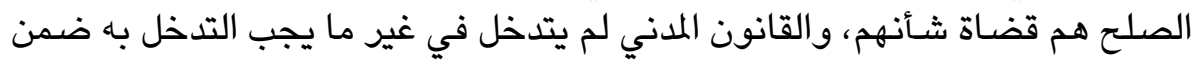
اتفاقهم، بل ترك للأطراف تحمل مخاطر عقد صلحهم، ونتائج تركهم للقضـاء(44).

(39) Mayer L., op.cit., p.523.

(40) Fourcade C., op.cit., p.167.

(41) Rayssac R, op.cit., p.79.

(42) Cass. Civ, 4-5-1976, Bull. civ. I. n¹57, R.T.D.C, 1976, p.812.

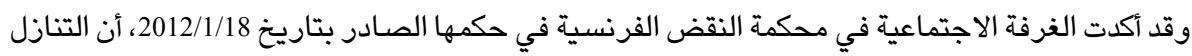

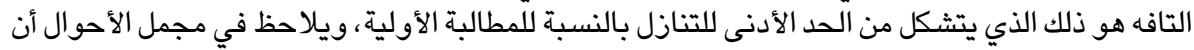

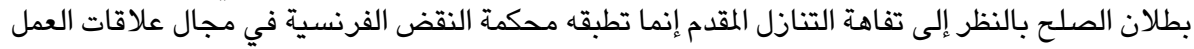

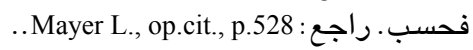

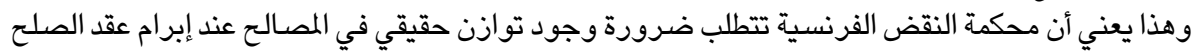

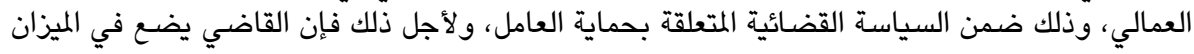

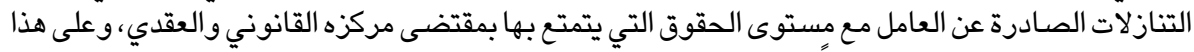

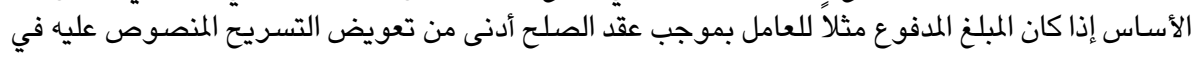

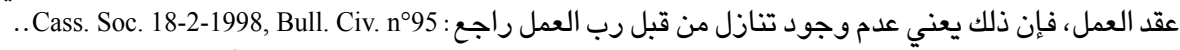

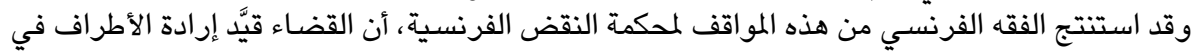

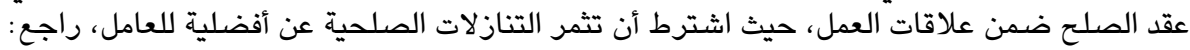

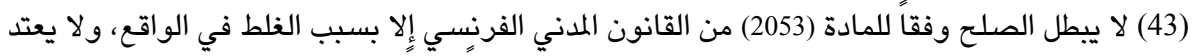

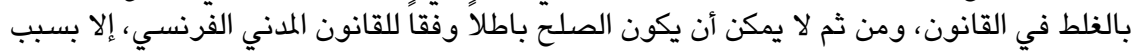

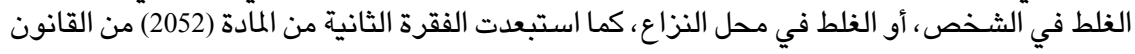

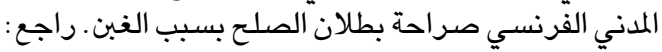

Chaaban R., L'article 2052 du code civil: erreur de rédaction ou erreur de droit? D, 2006, p.1513.et.s.

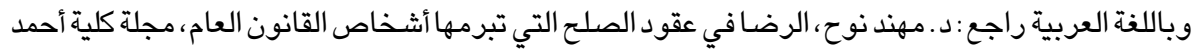

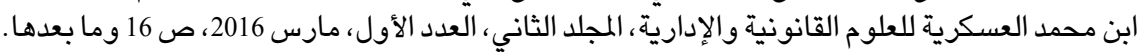
= (44) Jarrosson CH., op.cit., p.274. 


\section{المطلب الثاني}

\section{تطور مفهوم التنازلات المتبـادلة في عقود الصلـح الإداريتة في ضوء اجتهاد مجلس الدولة الفرنسي}

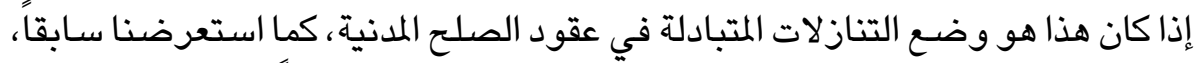

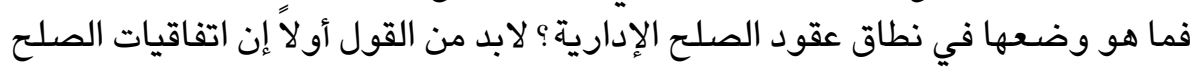

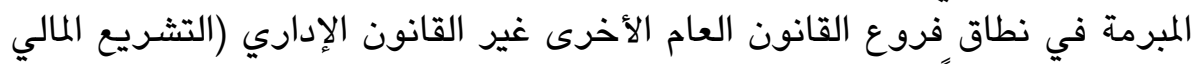

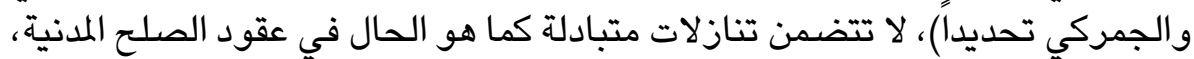

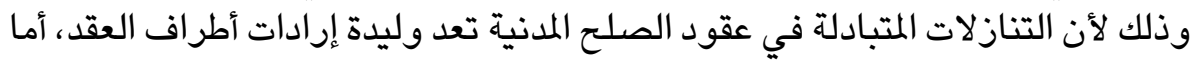

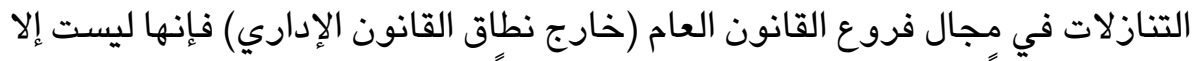
(إعفاءات) وفقا لما تمليه النصوص القانونية، وبعيدا عن أي عملية تفاوضية تتعلق بذلك، فئل

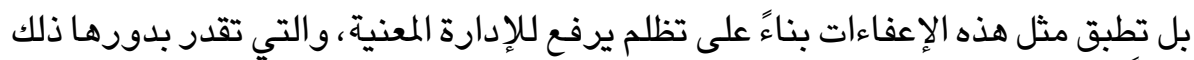

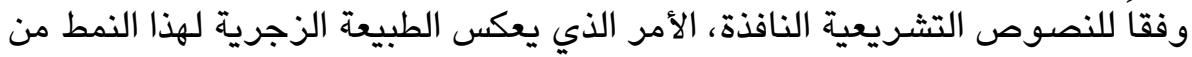
الصلح (45).

أما بالنسبة لعقود الصلح الإدارية، فإن اجتهاد القضـاء الإداري الفرنسي، لم يعبر

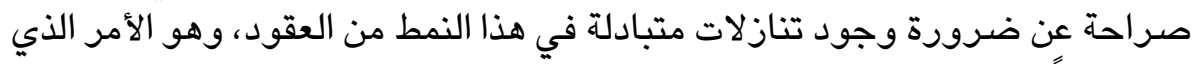

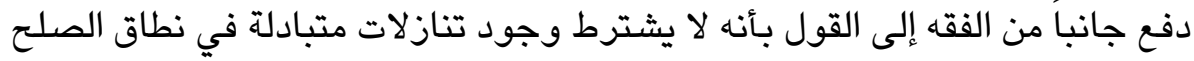

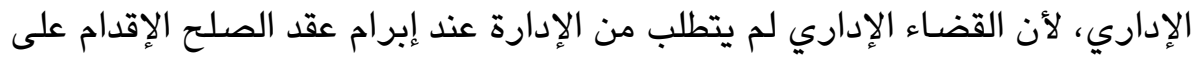

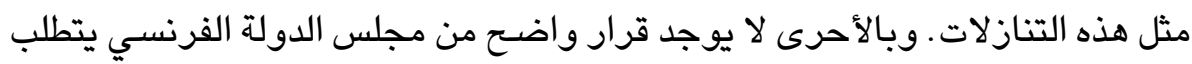

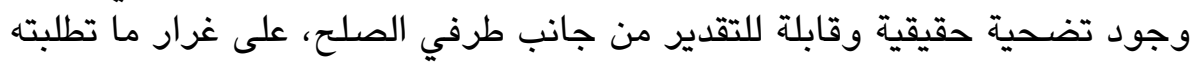

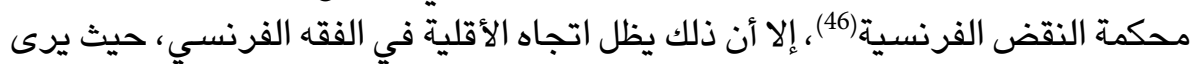

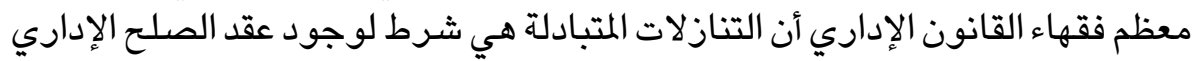

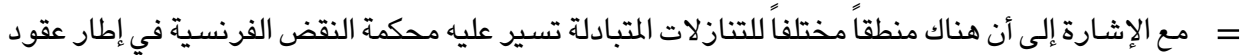

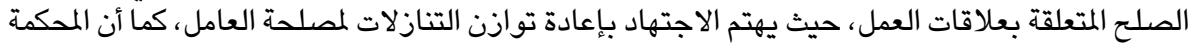
Cass.Soc.20-6-1995, J.C.P, 1996, II, n²2618.note.Finel.L.

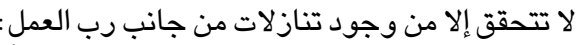

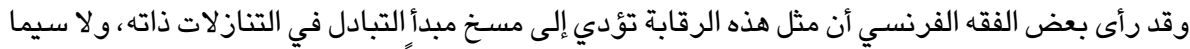

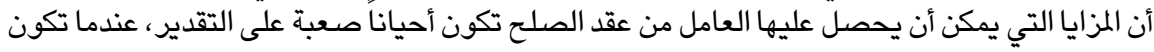

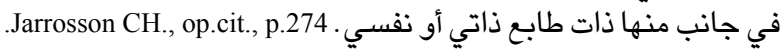

(45) Cornu J., op.cit., p.30.

(46) Chavrier G., op.cit., p.554. Chatelier L.G., Transaction, Répertoire de contentieux administratif, Dalloz, 2010, (dernière mise à jour: mars 2014), n²8. 
قانوناً، على أسـاس أن الصلّ سواء أكان إدارياً أم مدنياً يتضمن في جوهره مثل هذه التنازلات (47).

وقد قطع مجلس الدولة الفرنسي دابر الشك حول هذا الأمر، حين قرر بطلان عقد صلح أبرمته إحدى البلديات مع أحد متعاقديها، بسبب الخلل في تحديد التنازلات المتبادلة في مداولة المجلس البلدي على الصلح، وكذلك الخلل في تحديد هذه التنازلات ضمن فيل محرد

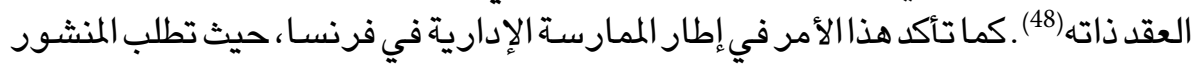

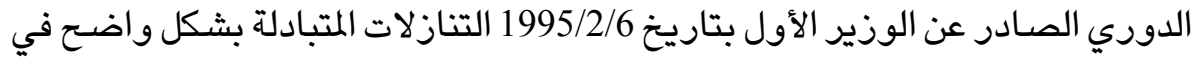

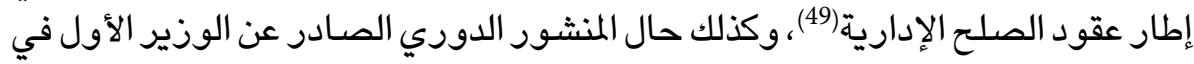

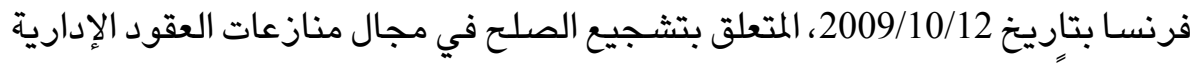

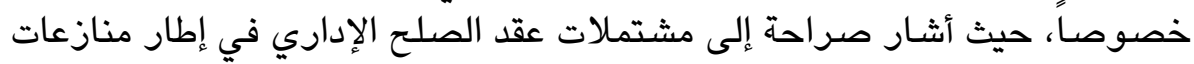

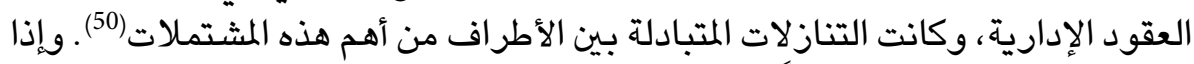

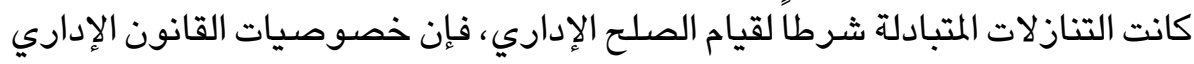

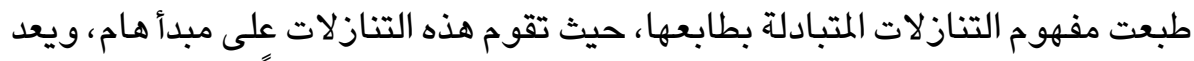

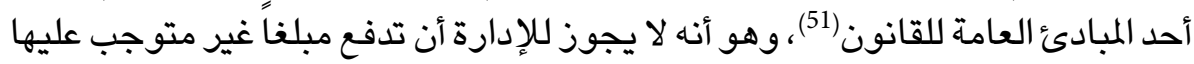
دفعه بمقتضى الصلح (52).

(47) Lyon-Caen. A., sur La Transaction en droit administratif, A.J.D.A, 1997, p.53. Richer L., Droit des contrats administratifs, L.G.D.J, Paris, 2014, p.283. Cornu J., op.cit., p.31. Dreyfus J.D, Transaction et commande publique: les frontières avec le délit de favoritisme, AJ. Collectivités Territoriales 2012, p.243. Dacosta B., L'homologation d'une transaction en cassation, RFDA, 2008 p.958.

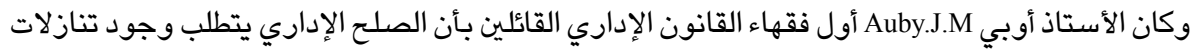

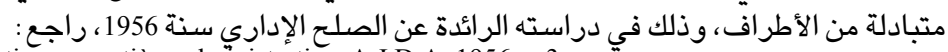

Auby J.M, La transaction en matière administrative, A.J.D.A, 1956, p.3.

(48) C.E, 11-9-2006, Commune de Théoule-sur- Mer, réq.n²55273.

(49) Chavrier G., op.cit., p.548.

(50) Linditch F., Une nouvelle circulaire pour encourager le recours à la transaction en matière de commande publique, J.C.P.A, $n^{\circ} 42,12$ Octobre 2009, p. 2235.

(51) Noury A., Les modes alternatives au règlement par les juridictions étatiques des litiges intéressant l'administration, op.cit, p.73.

(52) Dreyfus J.D, op.cit., p.488. Rayssac R., op.cit., p.76. Richer L., Droit des contrats administratifs, op.cit., p.583. Noury A., Les modes alternatifs peuvent-ils prospérer dans le contentieux administratif? J.C.P.A, $n^{\circ}$ 30-34, 25 Juillet 2005, $n^{\circ} 10$, p.1289. Dacosta B., op.cit., p.959. Soler-Couteaux et JeanJacques Louis, Du bon usage de la transaction administrative dans les contrats publics, Contrats et Marchés publics n 2, Décembre 2000, chron. 2. Yolka Ph., Traité de droit administratif, Les modes alternatifs de règlement des litiges administratifs, Dalloz, Paris, 2011, T2, p.603. Deliancourt S., Le contrôle du juge administratif sur le montant fixé par une convention de transaction pour des prestations réalisées hors contrat, AJDA, 2004, p.2270. Salvage F., Le caractère obligatoire d'une dépense née d'une transaction, RFDA, 2013, p.1292. 


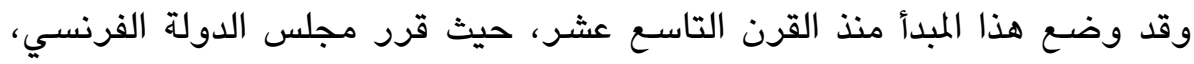

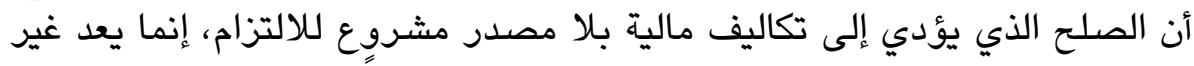

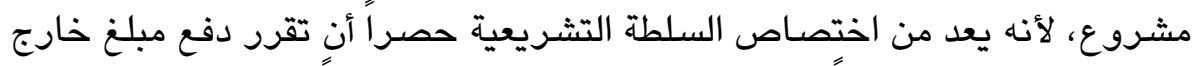

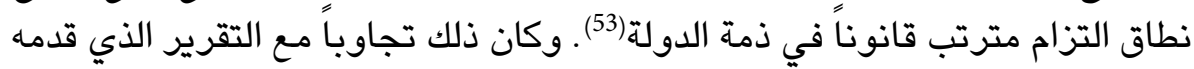

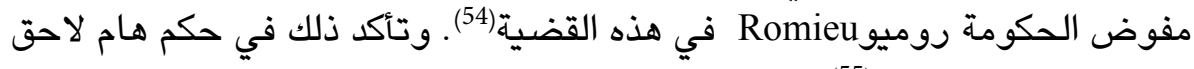

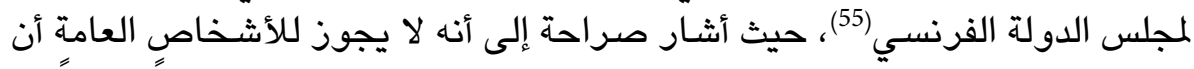

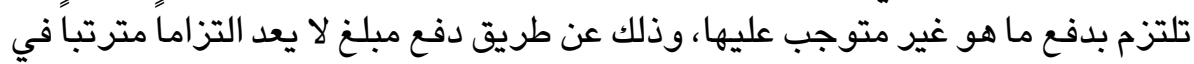

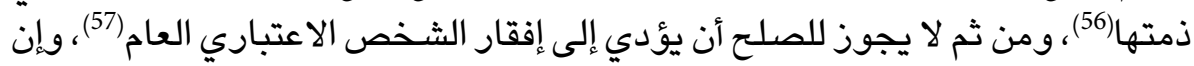

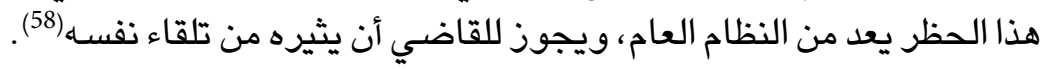
وقد أشـار مفوض الحكومة روجفان بافيل Rougevin-Baville إلى هذه القاعدة

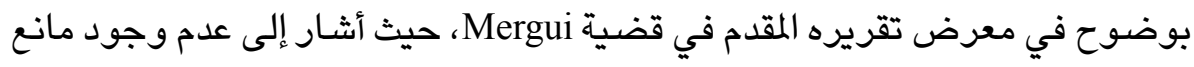

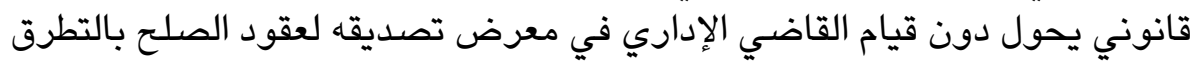

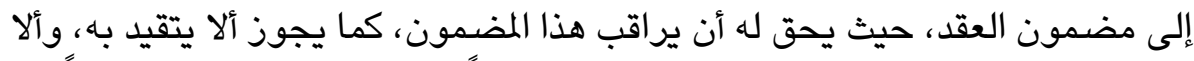

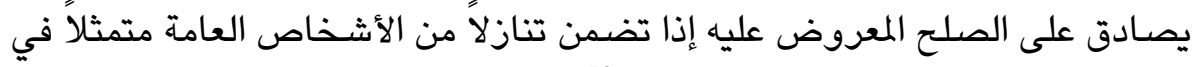

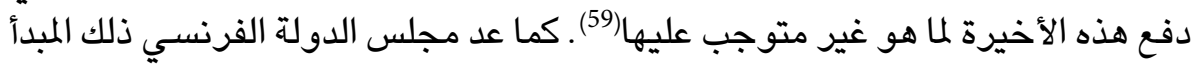

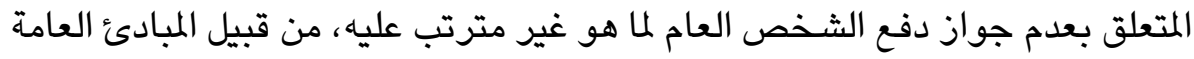

(53) C.E, 17-3-1893, Compagnies du Nord de l'Est et autres - ministre de la guerre, Ri.p245.S.1894, III, Pp.119 -126. concl. Romieu J.

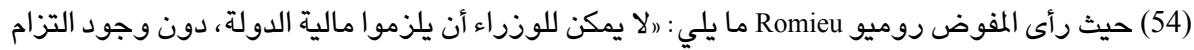

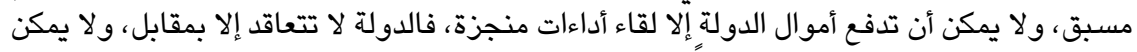

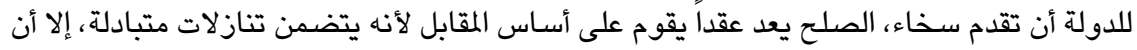

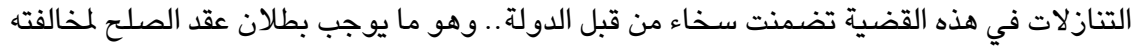

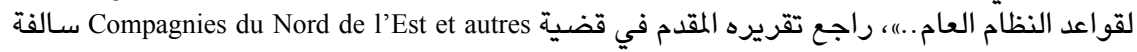

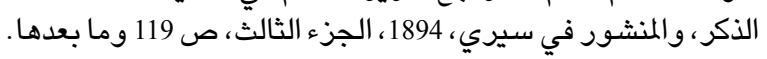

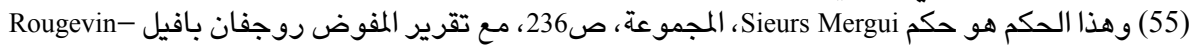

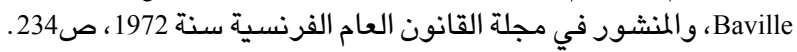

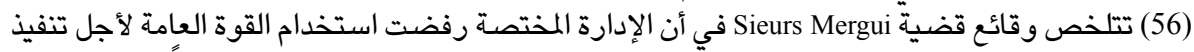

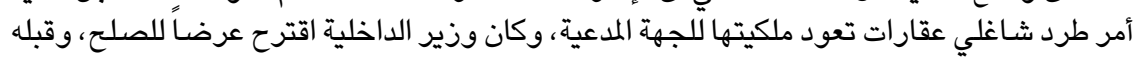

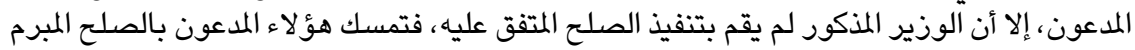

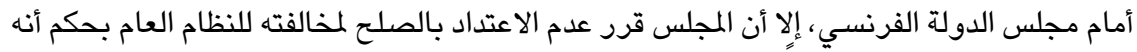

(57) Deliancourt S., op.cit., p.2270.

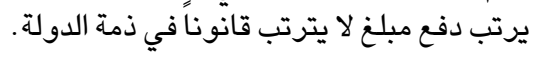

(58) Rayssac R., op.cit., p.56. Lyon-Caen A., op.cit., p.58.

(59) Rougevin-Baville, Conclusions sous C.E, 19-3-1971, Sieurs Mergui, Précité. 
للقانون(60). وعلى أسـاس ذلك، فإن قيام الأشخاص الاعتبارية العامة بلدفع ما هو غيرٍ متوجب عليها قانوناً عن طريق الصلّ الإداري من شـأنه أن يجعل هذا الأخير فاقداً

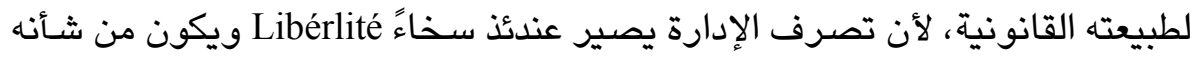
التفريط في المال العام، على حد تعبير مفوض لإن الحكومة روميو (61).

وإذا كان الأمر كذلك، فإن الصعوبة الرئيسية التي يمكن أن تثار في إطار التنازلات

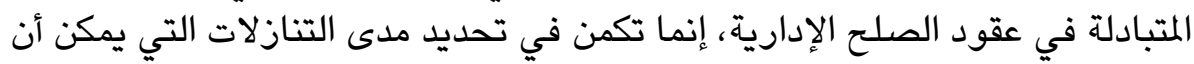

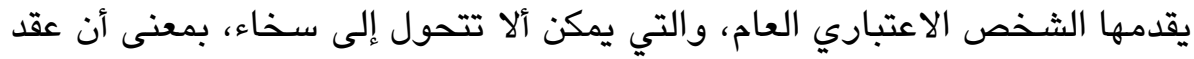

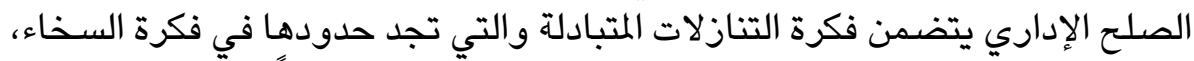

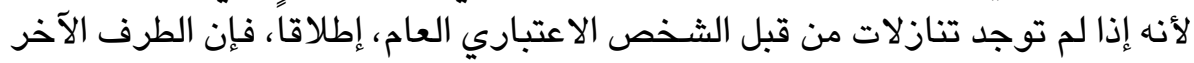
في الصلّح ليس له مصلحة في الصلّح(

لذلك فقد وضـع مفوض الحكومة روجفان بافيل Rougevin-Baville معياراً لتحول

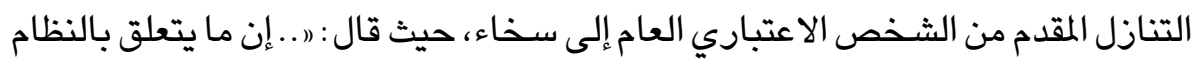
العام هو ألا تكون هناك مبالغة محتملة في التعويض المتفق عليه بين أطراف الصلّح، فدرجات جودة الصلح الإداري يمكن أن تكون محل تفاوت، حيث يمكن أن يكون الصلّح

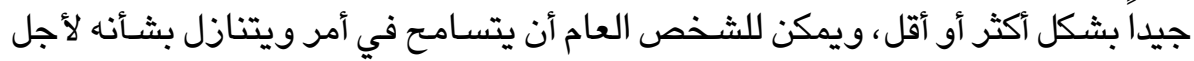

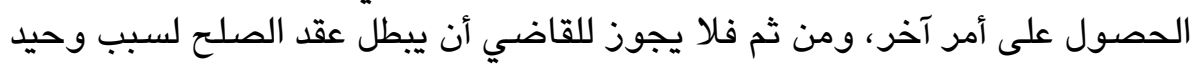

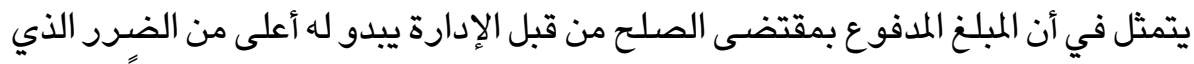

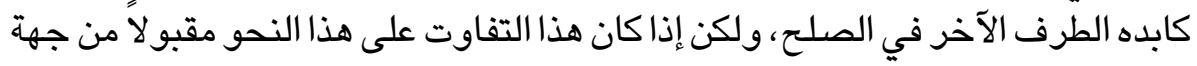

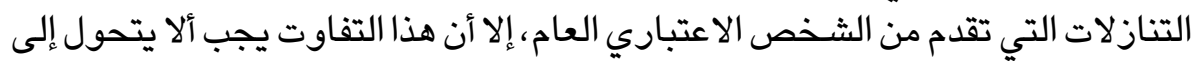
سـخاء، وإذا تحقق ذلك فلابد من إبطال الصلّح ..1)(63). وعلى هذا الأساس، يستتتج من رأي المفوض أن هناك تفاوتاً مقبولاً بين ما يجبَ دفعه (60) وذلك في حكم Mergui المشار إليه سـابقاً، وقبل ذلك في حكم صـادر عن مجلس الدولة الفرنسي بتاريخ

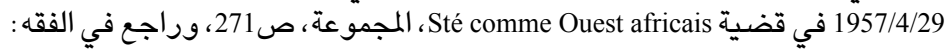

- Yolka Ph, op.cit., p.603. Dacosta B., op.cit., p.958 - Cornu J, op.cit,p.47

(61) Romieu J.C.E, 17-3-1893, Compagnies du Nord de l'Est et autres - ministre de la guerre, précité. : Chatelier. L.G, Transaction, Répertoire de contentieux administratif, op.cit., n40. Noury A., Les modes alternatifs peuvent-ils prospérer dans le contentieux administratif, op.cit., p.1290. Dacosta. B, op.cit., p.959. Soler-Couteaux et Jean-Jacques Louis, op.cit., chron.2.

(62) Chatelier L.G, Transaction, Répertoire de contentieux administratif, op.cit., $n^{\circ} 43$.

(63) Rougevin-Baville, Conclusions sous. C.E, 19-3-1971, Sieurs Mergui, Précité.

وراجح في الفقه الفرنس Noury A., Les modes alternatifs peuvent-ils prospérer dans le contentieux administratif, op.cît., p.1292. Dacosta B., op.cit., p.959. Cornu J., op.cit., p.47. 
وما دفع فعلاً بموجب الصلح من جهة، وتفاوتاً غير مقبول بين هذين العاملين من جهة

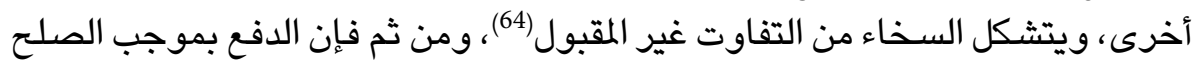

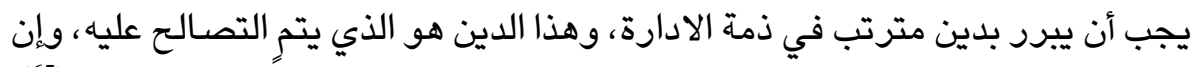

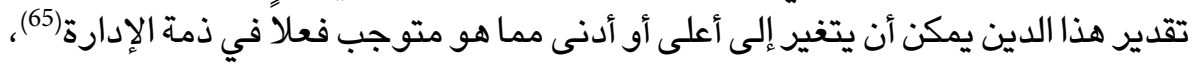

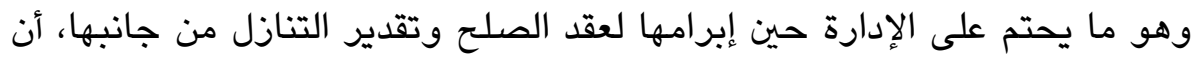

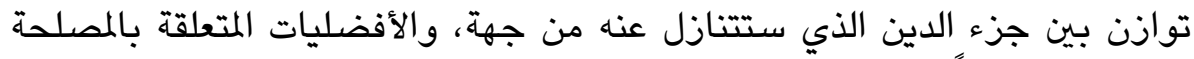

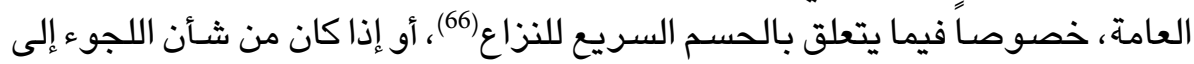

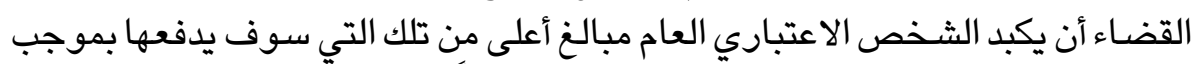

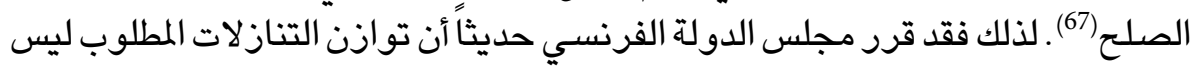

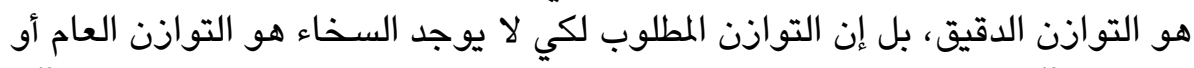

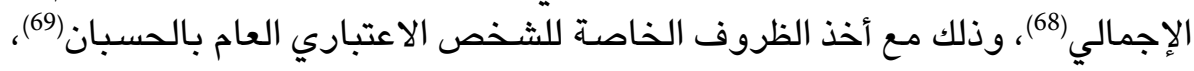

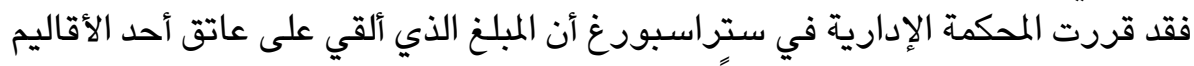

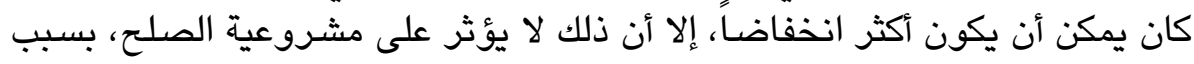

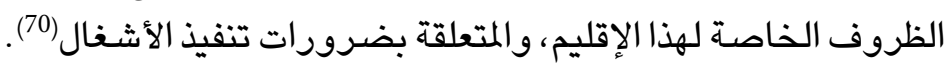

وقد توضـح معيار التنازل المقبول من قبل الإدارة في الصلح الإداري بشكل كبير مع

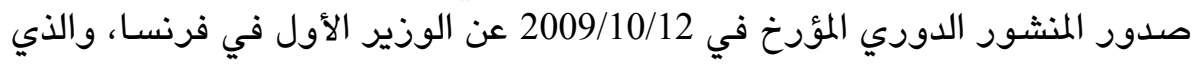

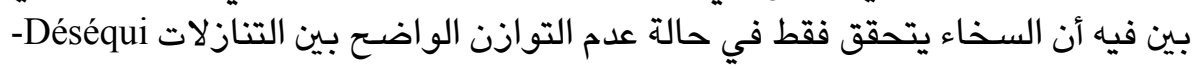
libre manifeste

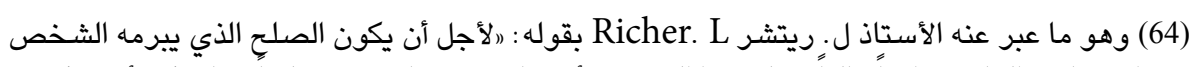

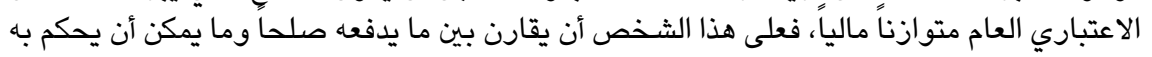

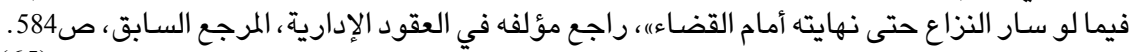

(65) Richer L., Droit des contrats administratifs, op.cit., p.584.

(66) Le Chatelier G., L'homologation juridictionnelle des transactions en droit administratif, R.F.D.A, 2003, p.293.

(67) فقد طلب أحد المكلفين من المحكمة الإدارية الترخيص لأجل الادعاء باسم البلدية التي ينتمي إليها ضد إلدا

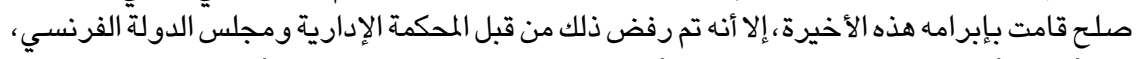

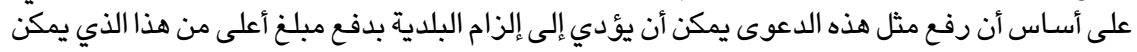

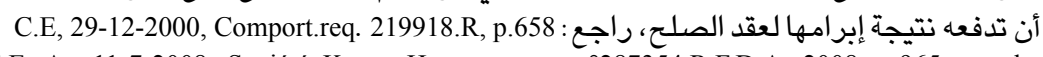

(68) C.E, Ass.11-7-2008, Société Krupp Hazemag, req.n²87354,R.F.D.A, 2008, p.965, conclusions. Decosta B.

-C.E, 29-12-2000, Comparat, req. n²10018.

(69) Chatelier. L.G, Transaction, Répertoire de contentieux administratif, op.cit, $n^{\circ} 58$.

(70) T.A, Strasbourg. 28-9-1999, Sté MS Aménagements, - Conseil régional d’Alsace, B.J.D.C.P, nº 10, p.165.

(71) Linditch F, Une nouvelle circulaire pour encourager le recours à la transaction en matière de commande publique, op.cit., p.2241. 


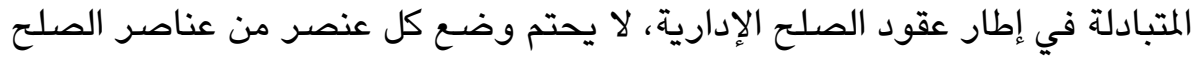

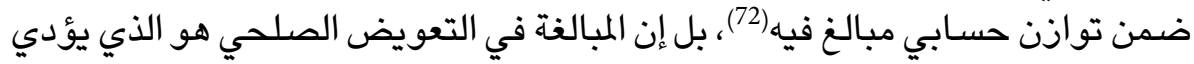

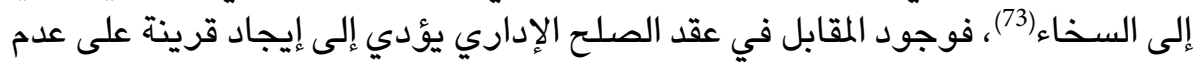

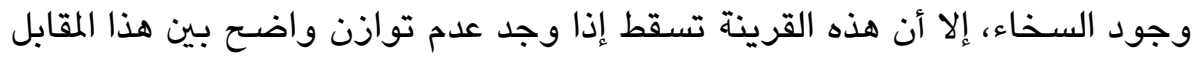

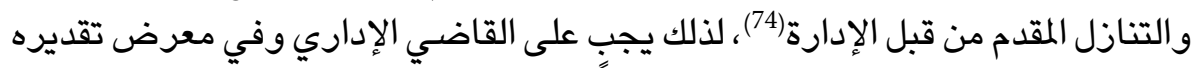

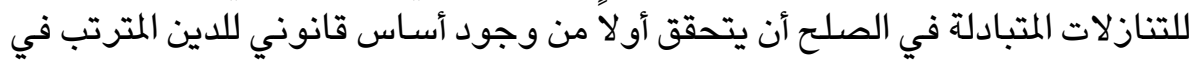

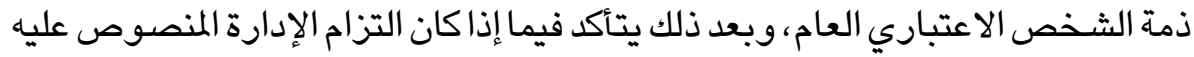

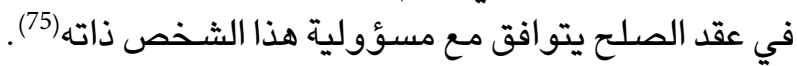

وعلي هذا الأساس يستتجج بعض الفقه الفرنسي أن الأشخاص الاعتبارية العامة تتمتع

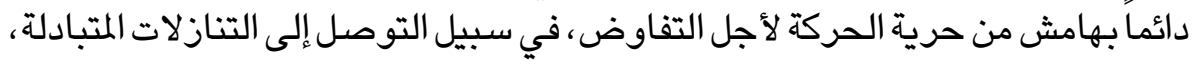

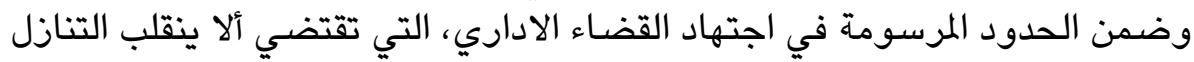
الصادر عنها إلى سخاء(76).

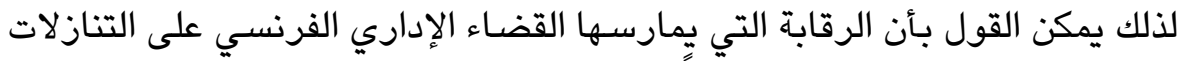

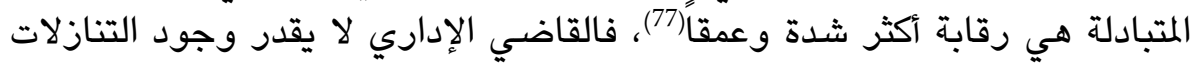

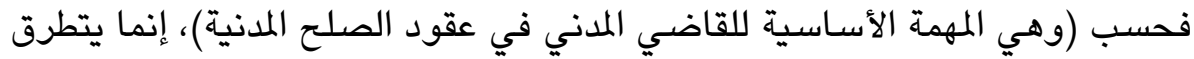

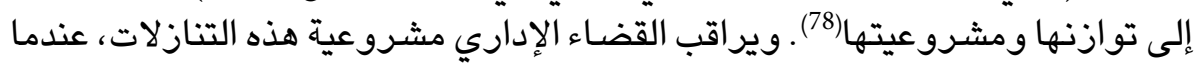

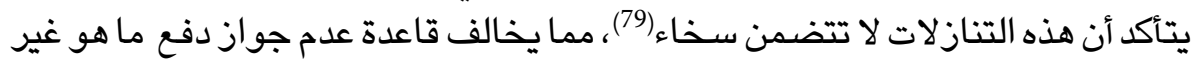

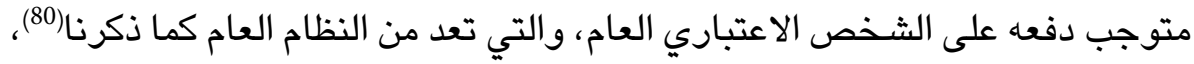

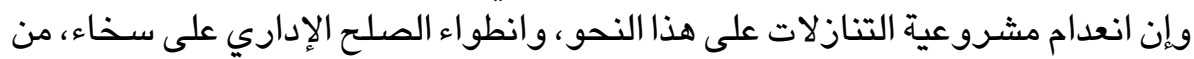

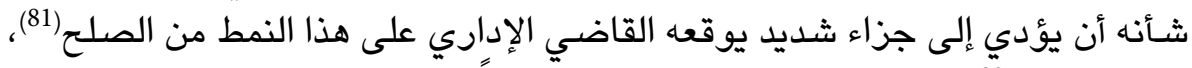

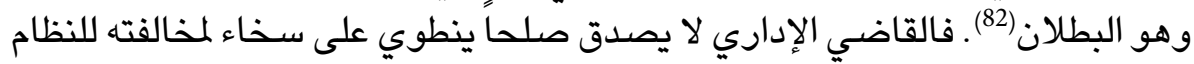

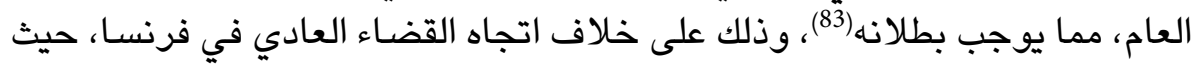

(72) Rayssac R., op.cit., p.79.

(73) Lyon-Caen A., op.cit., p.61.

(74) Dacosta B., op.cit., p.960.

(75) Rayssac R., op.cit., p.79.

(76) Rayssac R., Ibid, p.80. Soler-Couteaux et Jean-Jacques Louis, op.cit., chron. 2.

(77) Dacosta B., op.cit., p.956.

(78) Rayssac R., op.cit., p.80.

(79) Guettier Ch., op.cit., p.511.

(80) Le Chatelier G., L'homologation juridictionnelle des transactions en droit administratif, op.cit., p.298.

(81) Chatelier L.G,Transaction, Répertoire de contentieux administratif, op.cit., n49. Rayssac R., op.cit., p.80.

(82) C.E, 19-3-1971, Sieurs Mergui, Précité.

(83) Deliancourt.S, op.cit., p.2279. 


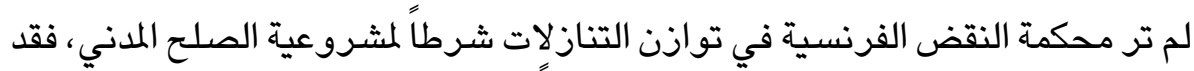

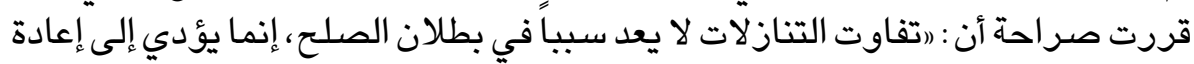
تكييفه إلى عقد آخر ..1)(84).

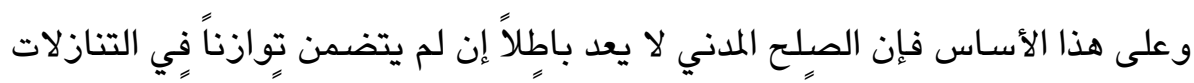

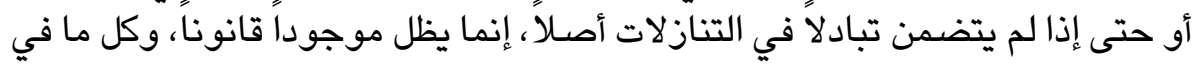

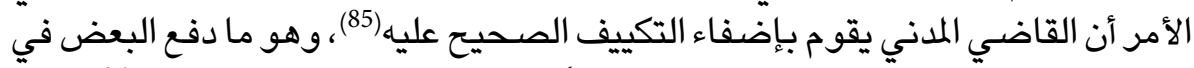

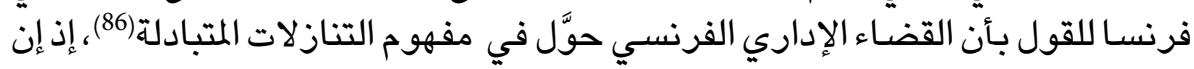

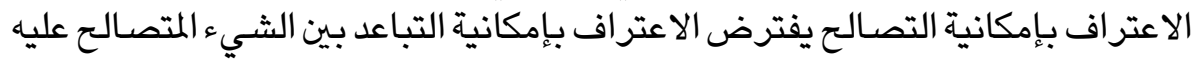
La chose susceptible d'être jugée والشيء الذيء La chose transigée

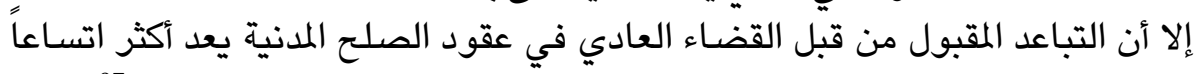

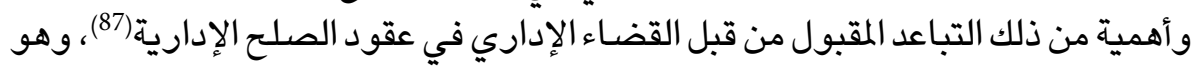

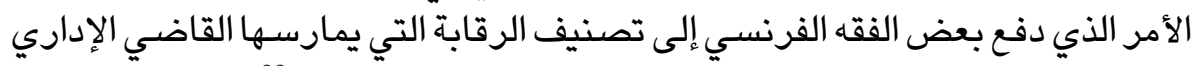
على وجود السـاء أو عدمه، ، في خانتة رقابة الغلط البين في التقدير (88).

أما بالنسبة للمبررات التي قادت القضـاء الإداري الفرنسي إلى هذا الوضـع في رقابة

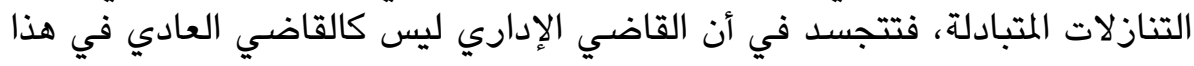

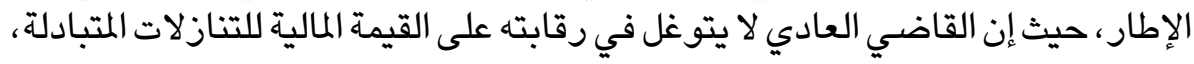

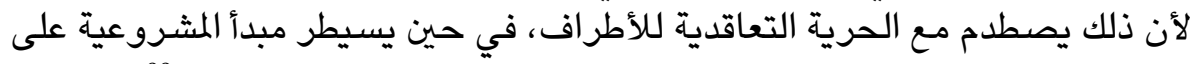

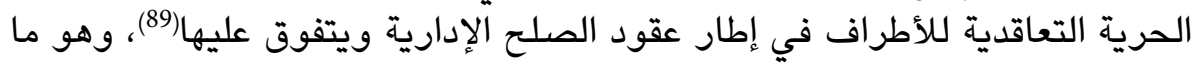

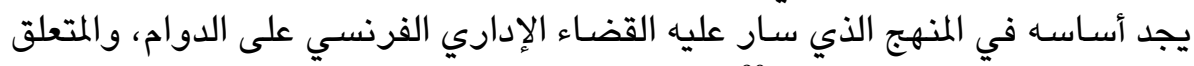

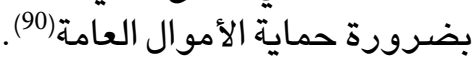

(84) Cass.Soc.17-3-1982, Bull.civ.n180.

(85) Jarrosson CH, op.cit, p.272. Cornu.J, op.cit., p.51. Noury.A, Les modes alternatives au règlement par les juridictions étatiques des litiges intéressant l'administration, op.cit., p.72. Fourcade C., op.cit., p.166.

(86) Cornu J., op.cit., p.51.

(87) Noury.A, Les modes alternatives au règlement par les juridictions étatiques des litiges intéressant l'administration, op.cit., p.73.

(88) Deliancourt S., op.cit., p.2279.

(89) Sauveplane M., Le juge administratif et la déclaration de nullité d'une transaction, RFDA, 2004, p. 1179.

(90) Yolka Ph, op.cit., p.603. Le Chatelier G., L'homologation juridictionnelle des transactions en droit administratif, op.cit., p.298.

وقد عبر المقرر العام سالفاج Salvage. F عن ذلك في تقريره المقدم لمحكمة استئناف مرسيليا الإدارية، في

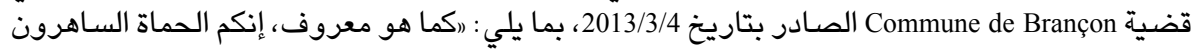

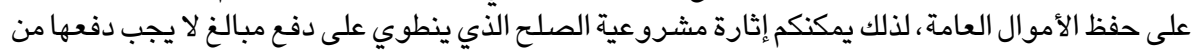

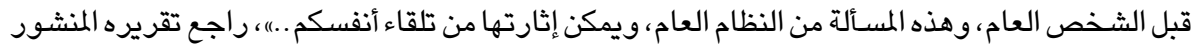

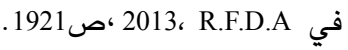


وبالنتيجة لذلك، فإن مفتاح فهم هذه الرقابة يجب ألا يبحث على أرضية تقنية لعقد

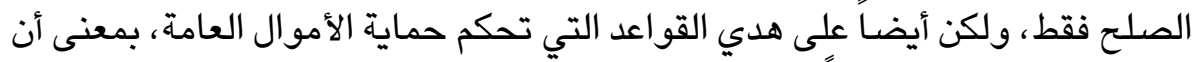

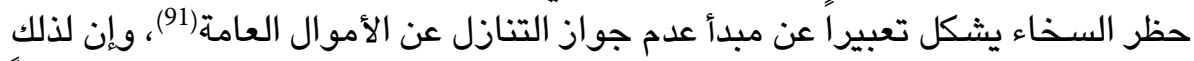

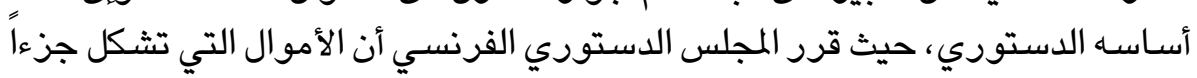

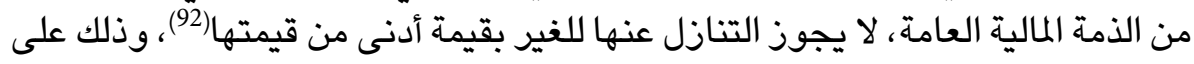
أسـاس المبدأ الدستوري المتعلق بحماية حق الملكية الوارد في المادتين 14 و15 من إعلان المان

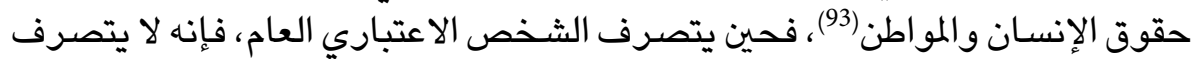
كأشخاص القانون الخاص، فهذا الأخير يتصرف الإن على أنه سيد حقوقه

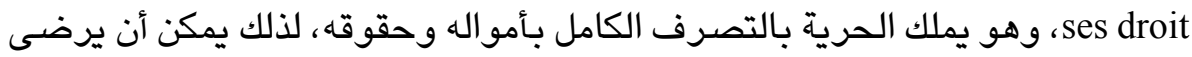

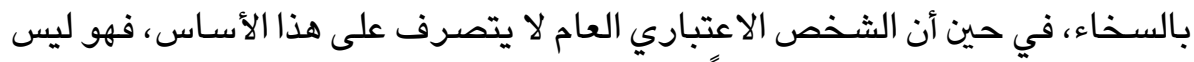

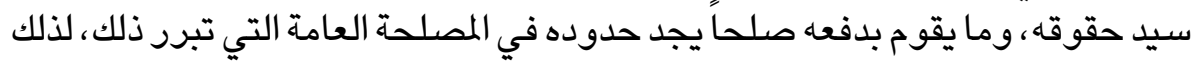

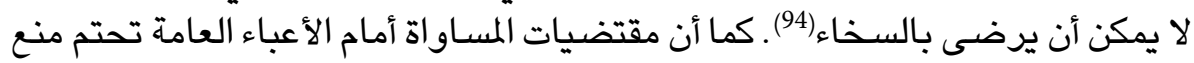
السخاء، لأن الصلح الذي يتضمن السخاء يؤدي إلى توزيع الأعباء العامـة بشكل غير عادل، مـع أفضلية واضحة لأن لمن تم التصـالح معه(95).

ومن جهة أخرى، لقد أقر القضـاء الإداري الفرنسي الصلّح المركب، كما هو حال القضـاء العادي، بحيث لا تقتصر التنازلات المتبادلة على العناصر التي تتعلق بالمعطيات الأولية للنزاع(96)، ومن ثم يمكن أن يكون التنازل عبارة عن التزامات جديدة يقوم بها أحد

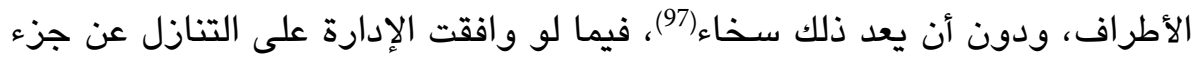

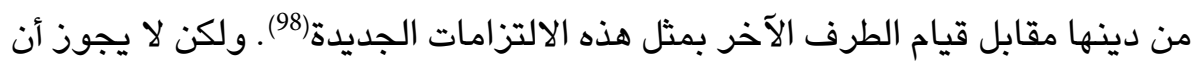

(91) Yolka Ph., op.cit., p.604.

(92) C.C, 25-6-1986, nº86-207.D.C,A.J.D.A, 1986, P575. C.C. 24-2-2008, n²008-567.D.C, A.J.D.A, 2008, p.1664, Note, Dreyfus.J.D.

(93) Chatelier. L.G,Transaction, Répertoire de contentieux administratif, op.cit, nº 49. Dreyfus J.D, op.cit., p.488.

(94) Dacosta B., op.cit, p.958. Rayssac R., op.cit, p.53. Lyon-Caen A., op.cit., p.48.

(95) Lyon-Caen A., Ibid, p.48. Rayssac R., op.cit, P53. Cornu J., op.cit., p.47. Le Chatelier G., L'homologation juridictionnelle des transactions en droit administratif, op.cit., p.298.

(96) Dacosta B., op.cit., p.958.

(97) C.E, 30-10-1974, Commune de saint - Pierre-Les-Bois -c- Sieur Gonin R., p.525.

(98) وهذا ما حدثٍ في إحدى المنازعات التي انتهت إلى إصدار مجلس الدولة الفرنسي لأحد أحكامه

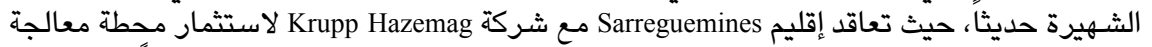

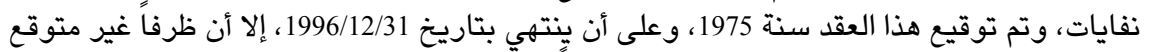

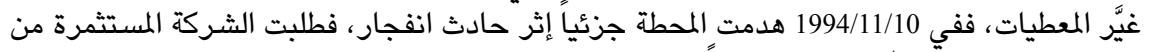

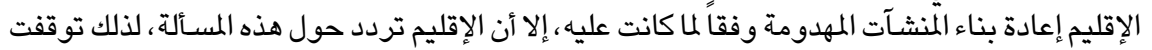

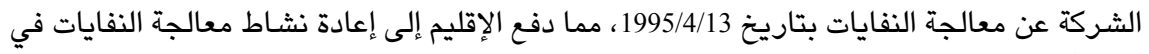

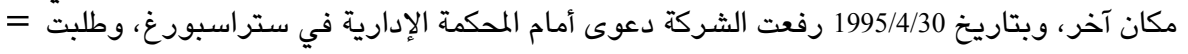


يتضمن الصلّح تقديم معونات مخالفة للقانون من قبل الإدارة للطرف الآخر في الصلّح وإلا عد ذلك سخاء(99).

ولا يأخذ النظام القانوني لعقد الصلح الإداري بالحسبان حقوق الشَصص الاعتباري

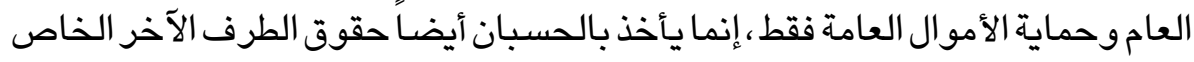

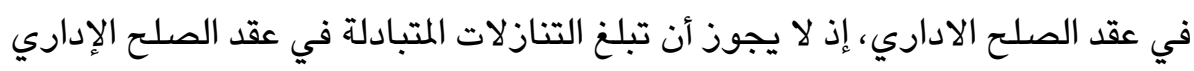
من السوء، بحيث تؤدي إلى هدر كلي لحقوق هذا الأخير، لذلك قضى مجلس الدي الدولة

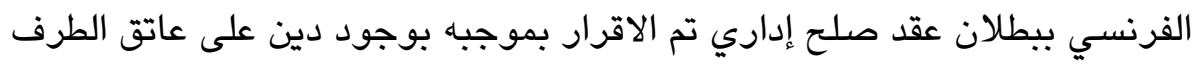

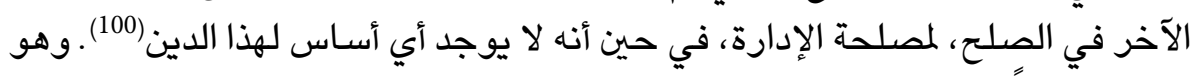

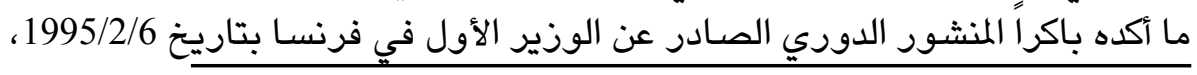
فيها الحكم بفسخ العقد، وإدانة الإقليم بدفع تعويض لها بسبب الضرر الناجم عن الأخطاء التعاقدية

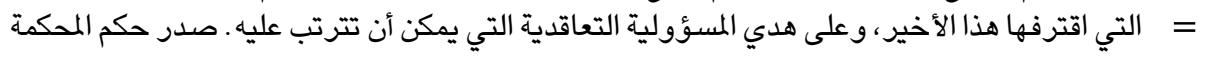

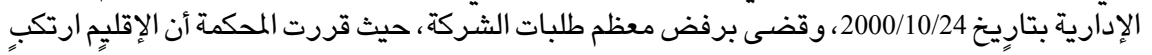

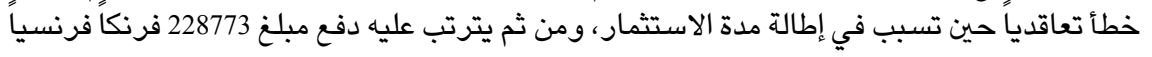

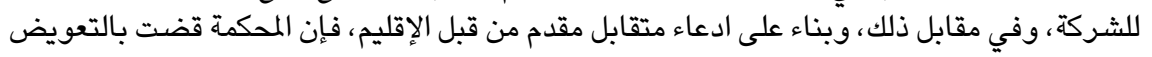

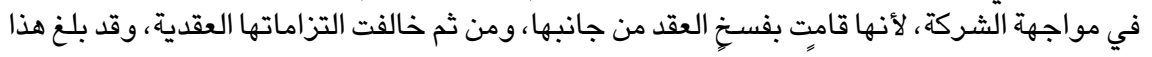

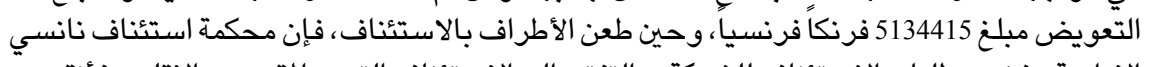

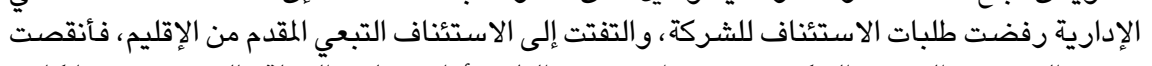

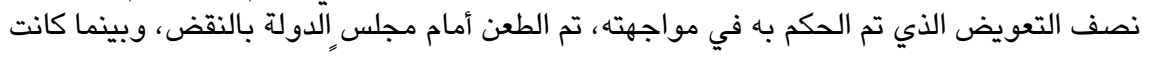

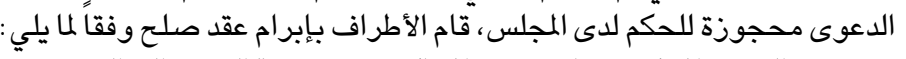

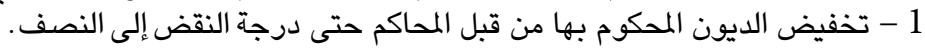

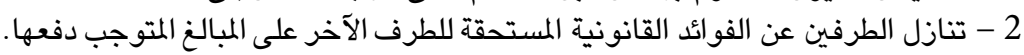

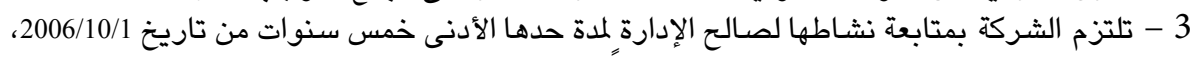

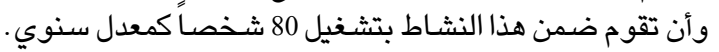

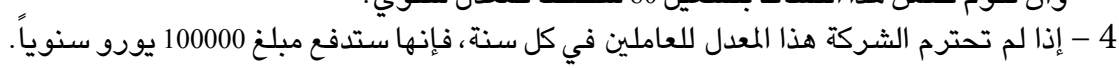

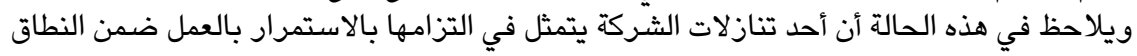

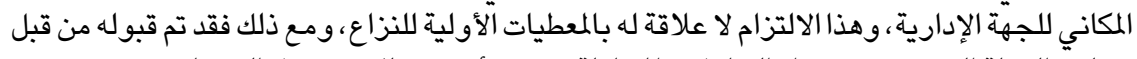

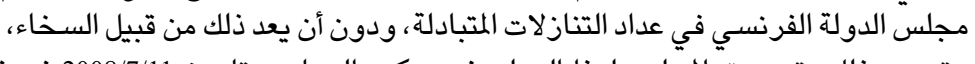

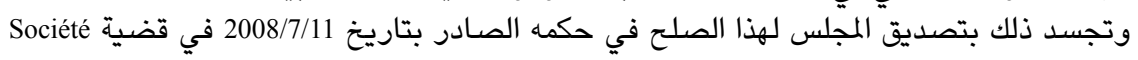

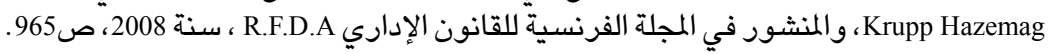

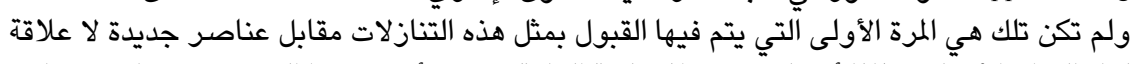

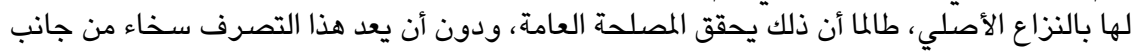

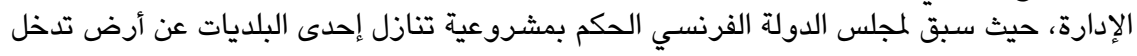

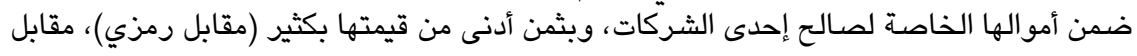

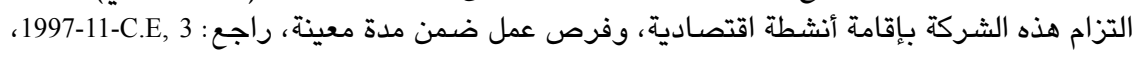

(99) Dacosta B., op.cit., p.962.et.s.

.Commune Fougerolles, R., p.391

(100) C.E, sect, 17-3-1978, Société anonyme (Entreprise Renaudin), R.P140. Concl. Galabert.M. 
حيث أثـار إلى ضرورة أن تتوخى الإدارة في إطار عقود الصلح الإدارية البحث عن

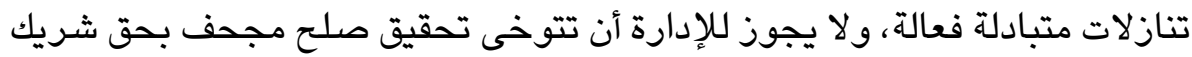

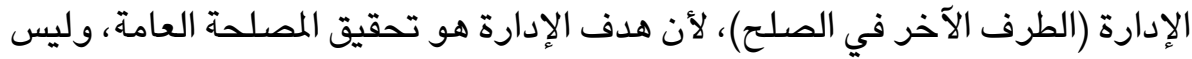

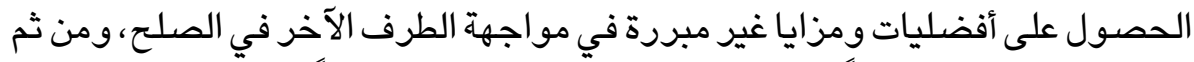

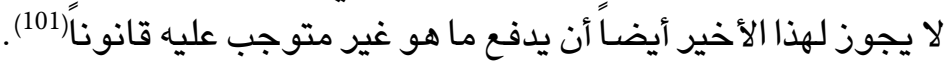

وقد عد مجلس الدولة الفرنسي قاعدة عدم جواز دفع الطرف الآخر في الصلح ما هو

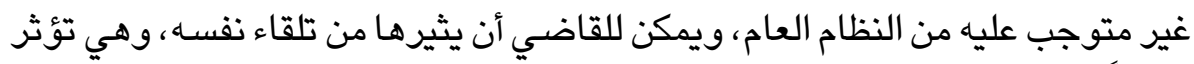

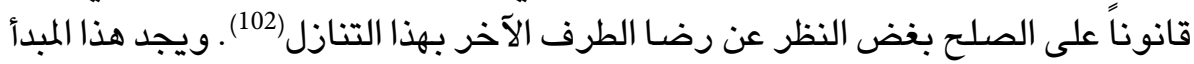
أصوله حسب ما عبَّر مجلس الدولة الفرنسي ضمن الفمن مبدأ المساواة في الوسائل القضائية

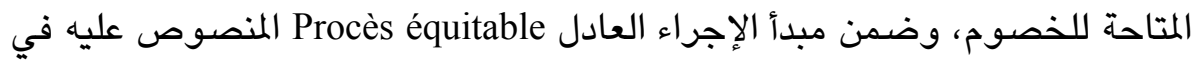
المادة (6) من الاتفاقية الأوروبية لحقوق الإنسان، وكذلك ضمن مبدأ مساواة أطراف

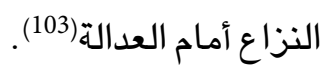

أما بالنسبة للمجالات الصلحية التي طبَّق فيها مجلس الدولة الفرنسي قاعدة عدم جواز التهاز

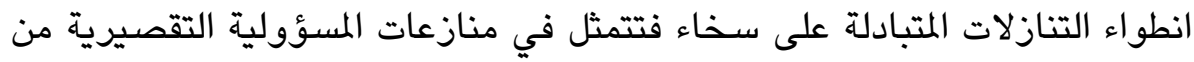

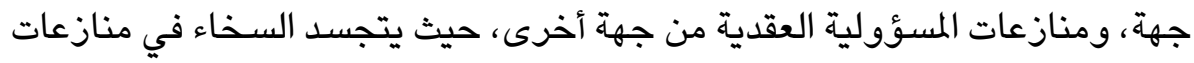

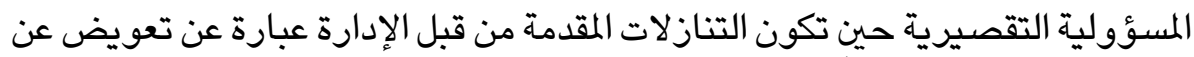

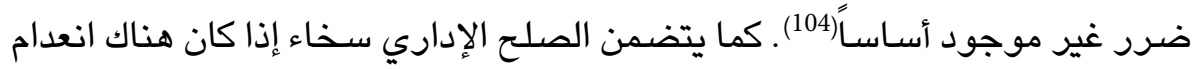

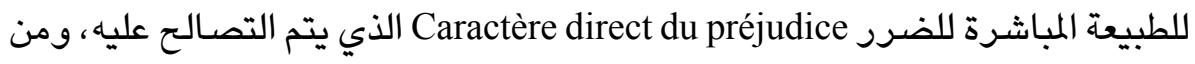

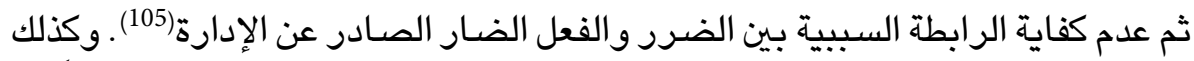

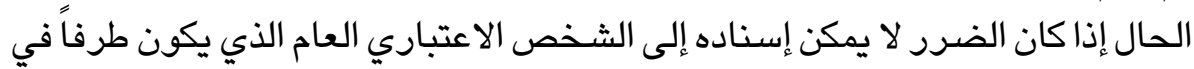
الصلّ (106).

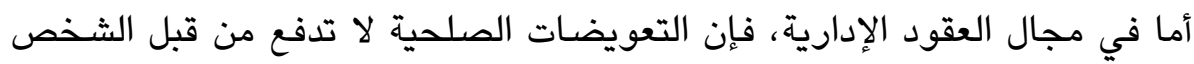

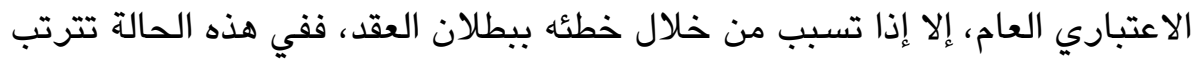

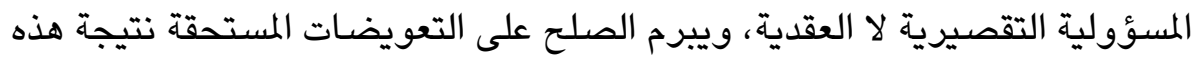

(101) Circulaire du 6-2-1995, Précité.

(102) C.E, 17-3-1978, Société anonyme (Entreprise Renaudin), précité.

(103) C.E, 5-7-1985, Cat, J.C.P, 1985, II, 20478, Concl. Jeanneney.

(104) C.E, 29-4-1957, Société commercial de l'ouest Africain, R.P271.

(105) C.E, 8-1-1975, Ministre de L'management du territoire de l'équipement du logement et du tourisme, R.P11.

(106) C.E, 8-2-1957, Dame Stergios,R.P100. 
المسؤولية، أو قد تدفع هذه التعويضـات على أسـاس الإثراء بلا سبب إذا تم إبطال العقد

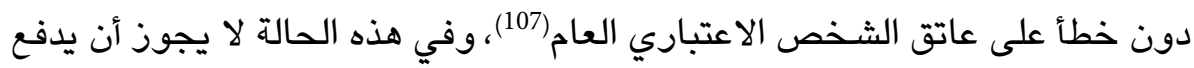

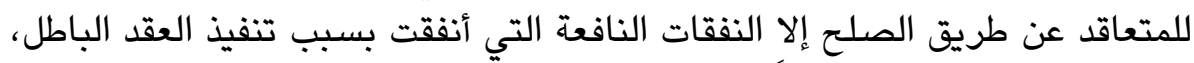

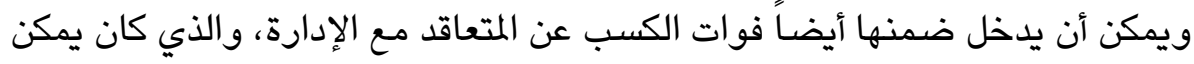

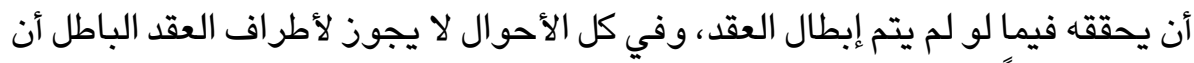

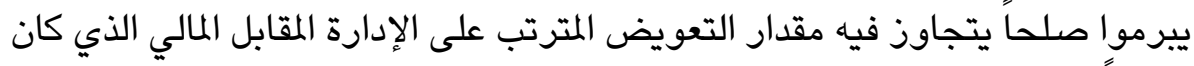
محدداً في العقد الباطل(108).

وفي هذه الحالة يراقب القاضي الإداري النفقات المدفوعة من قبل المتعاقد في معرض

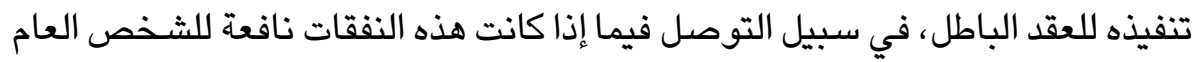
بشكل حقيقي، كما يتحقق من السلوك الخاطئ لهذا الأخير للتحري فيما إذا كان هذا السلوك هو السبب في بطلان العقد(109)، كما يتحقق أن الطرف الآخر في الصلّح (المتعاقد

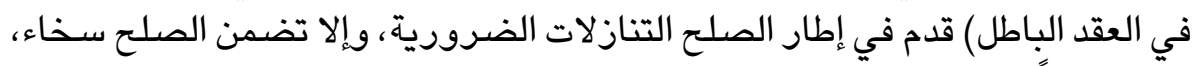
وكان باطلاً (110).

\section{المطلب الثالث \\ التنازلات المتبـادلة في عقود الصلّح الإداريتية \\ في النظام القانوني في سوريـة وقطر}

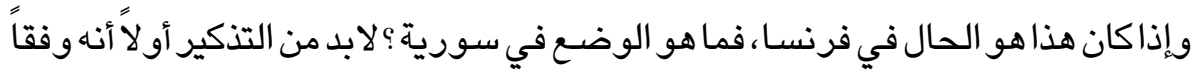

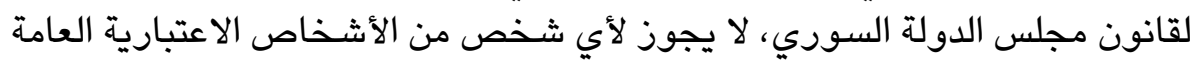

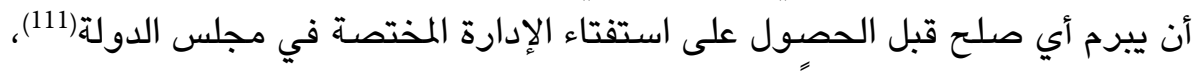

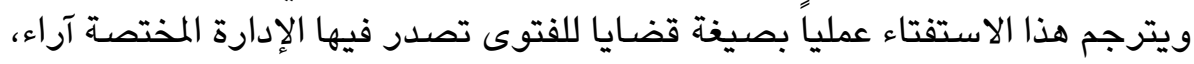
وهذا هو المجال الذي يمارس فيه مجلس الدولة السـوري رقابته على عقود الصلح المبرمة

(107) Richer L., Droit des contrats administratifs, op.cit., p.284. Cornu J., op.cit., p.49 et s. Chatelier L.G, Transaction, Répertoire de contentieux administratif, op.cit., $\mathrm{n}^{\circ} 52$. Soler-Couteaux et Jean-Jacques L,op.cit,chron.2.

(108) C.E.Che de Saint - Troprez.R.P432.A.J.D.A, 1996, p.448.

(109) C.E. 29-12-1997, Sté d'économie mixte de sécurité active et de télématique, req.n¹54320.

(110) T.A.Lille, BJDCP.n²3-302.concl.Lepers.M.

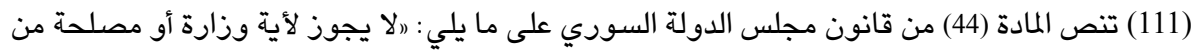

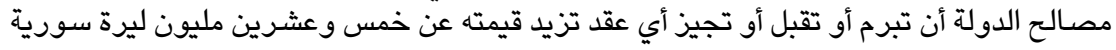

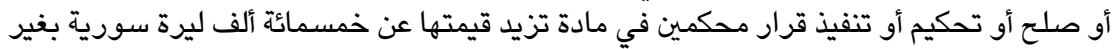

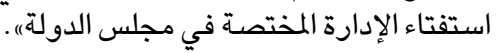


من قبل الأشخاص الاعتبارية العامة. ومن خلال هذه الآلية القانونية لرقابة مجلس الدولة السوري على عقود الصلح المبرمة من الأشخاص الاعتبارية العامة، يمكن القول

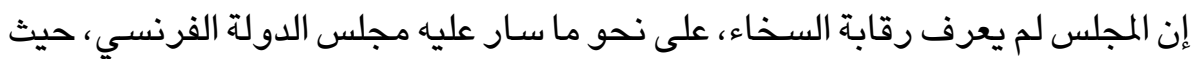
لم يقم بالتطرق إلى التنازلات المتبادلة في سبيل تقييمها، والتحقق من عدم قيام الإدارة بدفع ما هو غير متوجب عليها عن طريق الصلّح، بل اكتفى بتصريح الإدارة بأن الصلّح

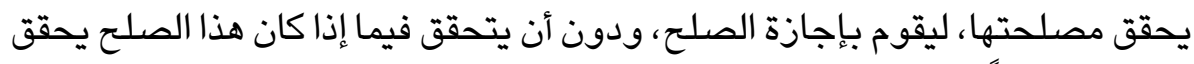

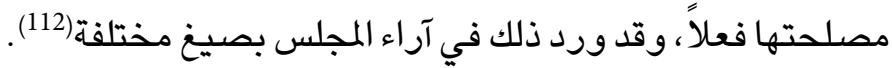
وفي بعض الحالات يُلاحظ أن مجلس الدولة السوري يُعلقِ إجازته للصلّح المبرم من قبل الإدارة ليس بسبب تطرقه إلى جوهر التنازلات المتبادلة وفحصـه لها، إنما لأن الإدارة ذاتها لم تُبِيّن وجود مصلحة لها في الصلح ، وبحيث يكون هذا الصلّ نافذاً، بمجرد إقرار

(112) رأي مجلس الدولة السوري رقم 12 لسنة 2013 (غير منشور)، والرأي رقم 199 لسنة 2004 في

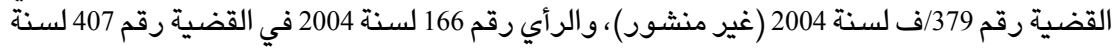

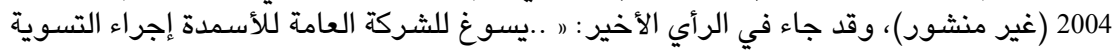

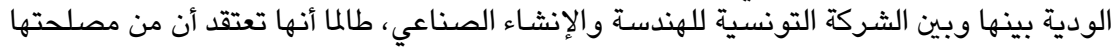

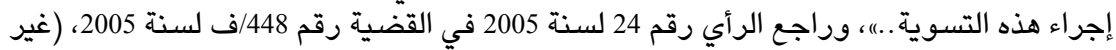

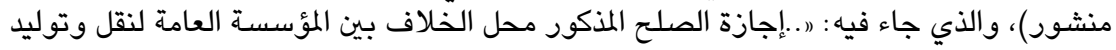

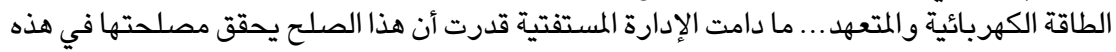

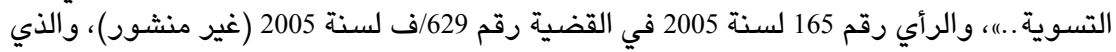

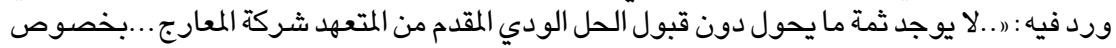

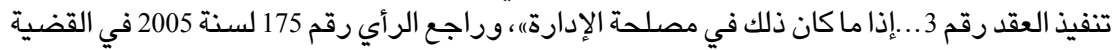

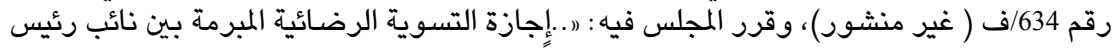

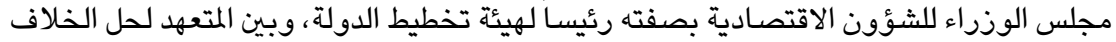

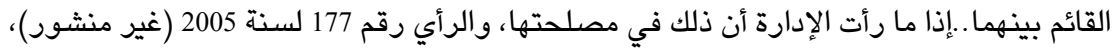

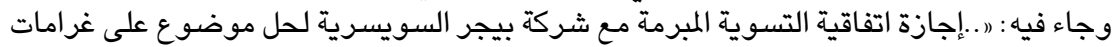

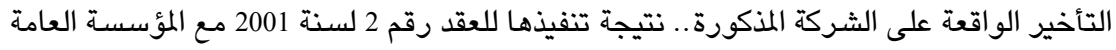

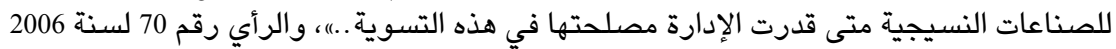

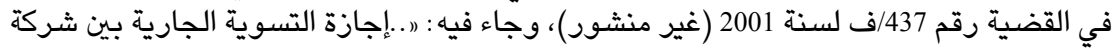

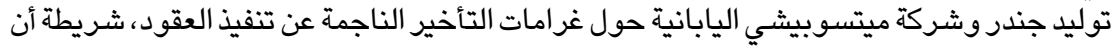

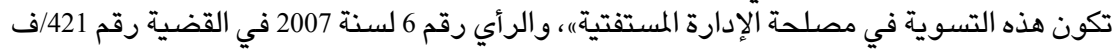

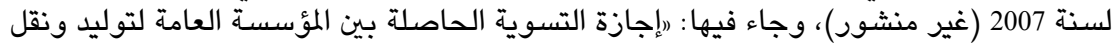

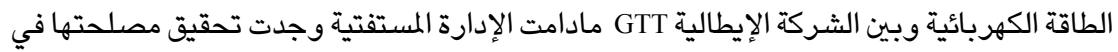

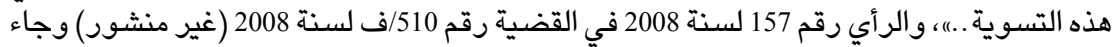

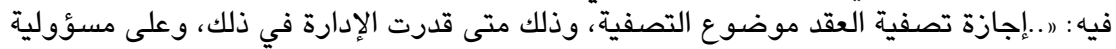

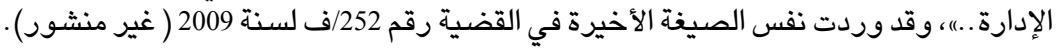




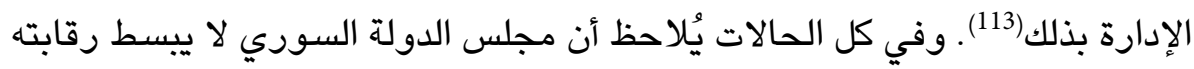

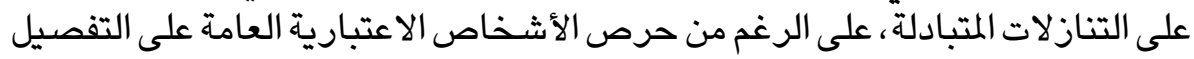

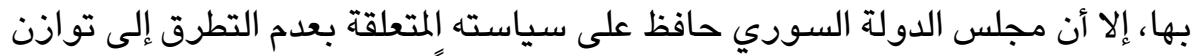

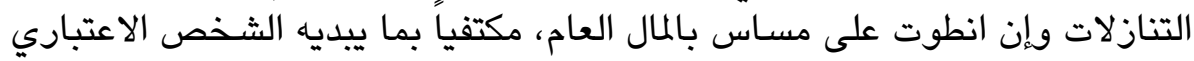

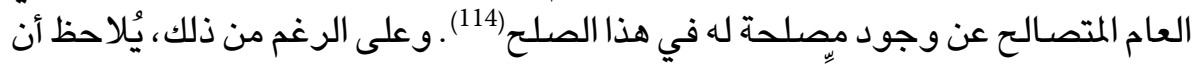

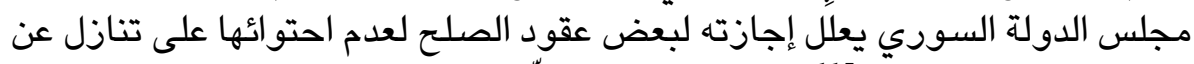

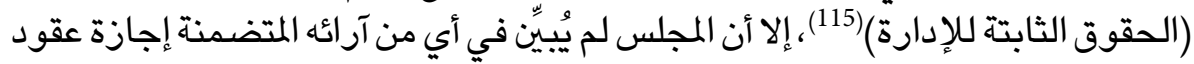

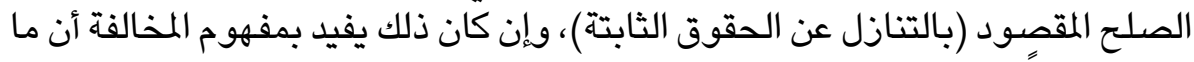

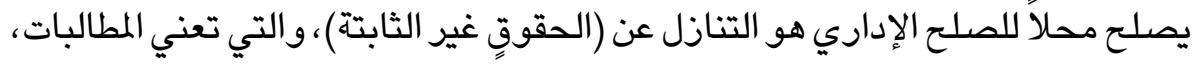

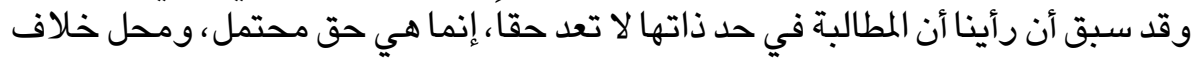

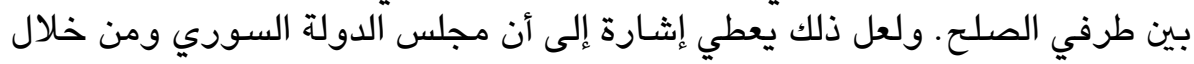

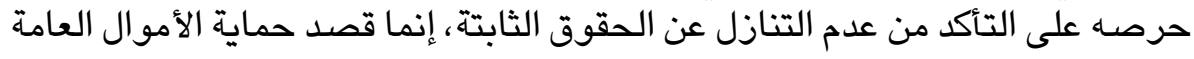

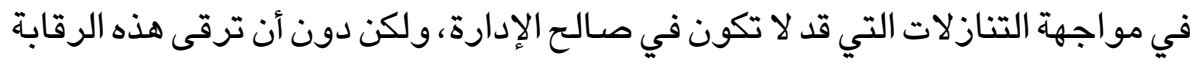

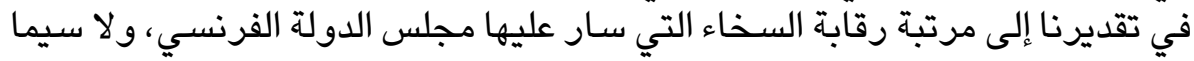

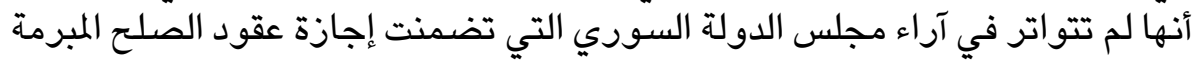
من قبل الأشخاص الاعتبارية العامة.

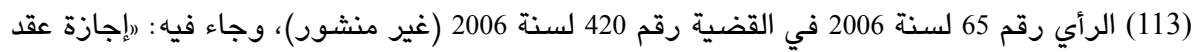

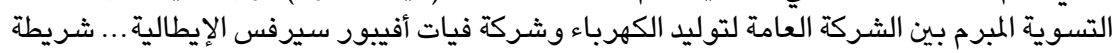

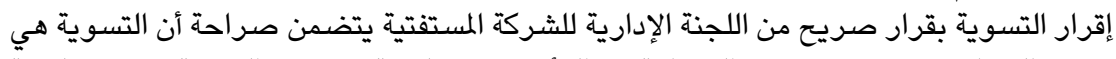

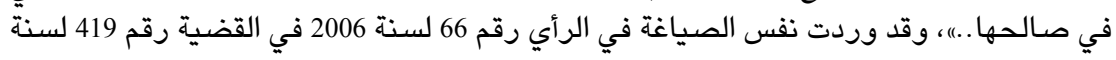
2006 (غير منشور).

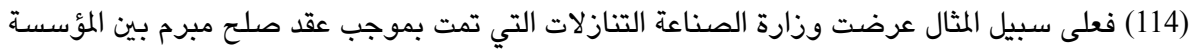

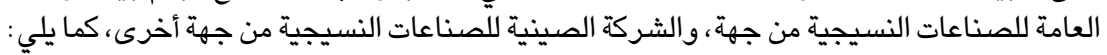

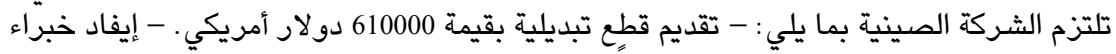

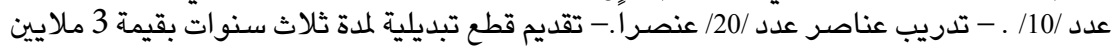

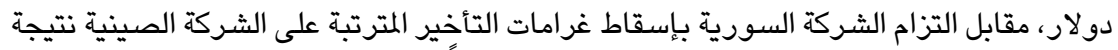

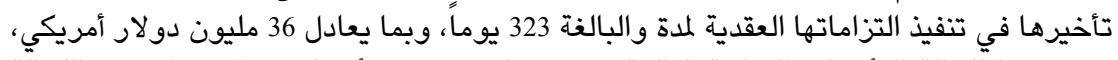

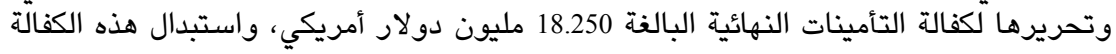

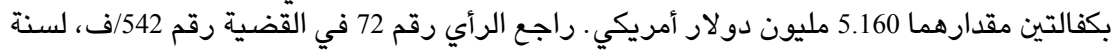

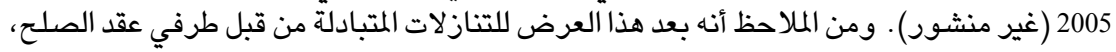

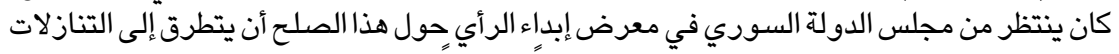

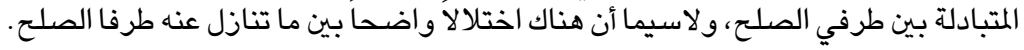

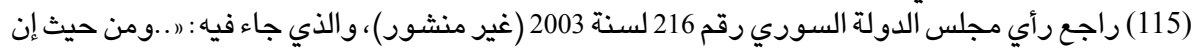

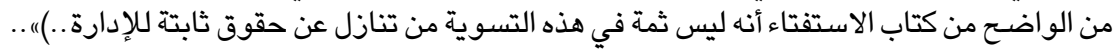

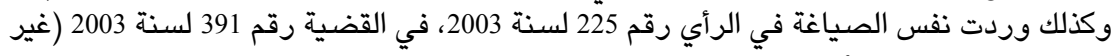
منشور)، وكذلك في الرأي رقم 7 لسنة السي ركية 2007 في القضية رقم 422/ف لسنة 2007 (غير منشور). 


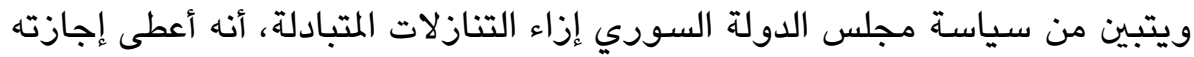

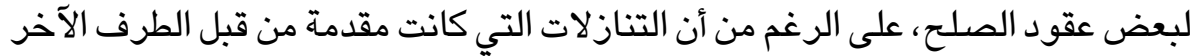
عبارة عن تنازل عن الدعوى فقط، ومقابل أن تقوم الإدارة بدفع كافة مطالبات المات المتعاقد

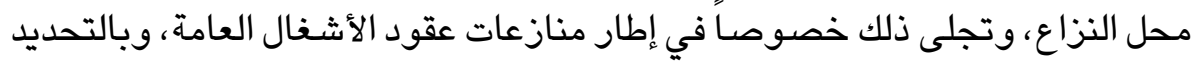

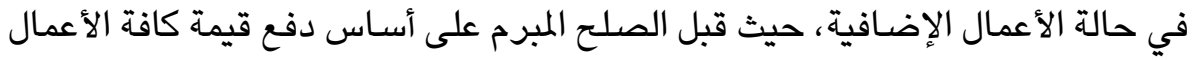

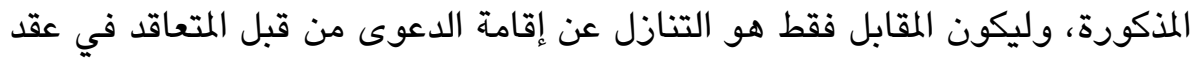

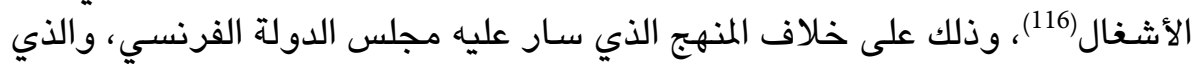

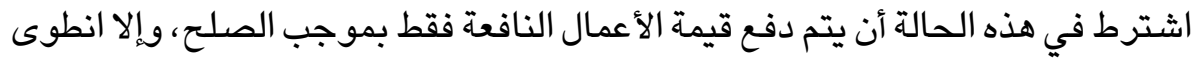
الصلح على سخاء.

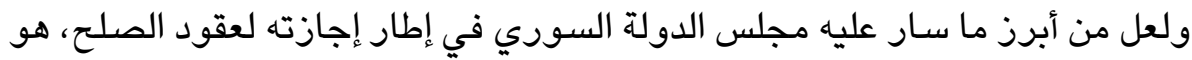

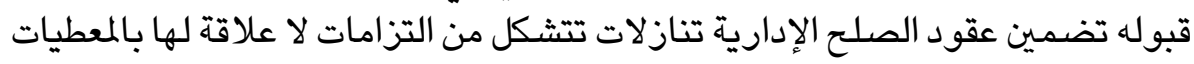

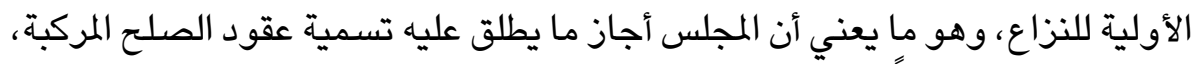

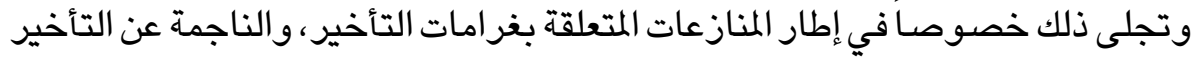

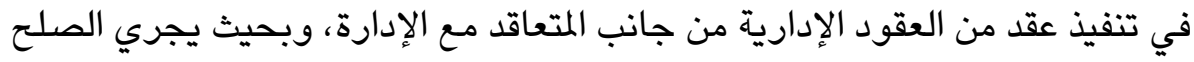

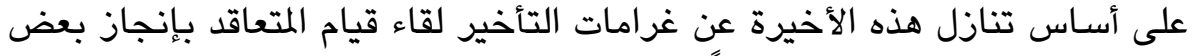

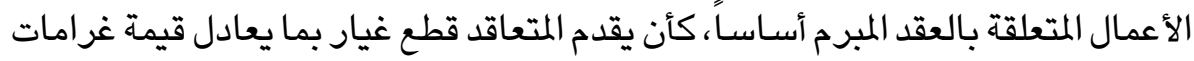

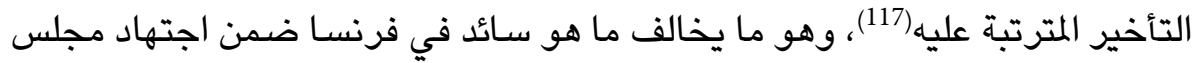

(116) راجع رأي مجلس الدولة السوري رقم 211 في القضية رقم 679/ف لسنة 2005 ( غير منشور)، والرأي

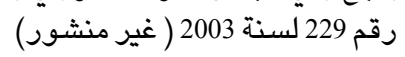

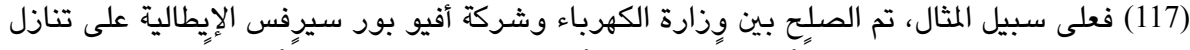

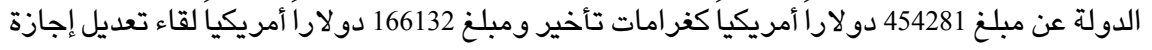

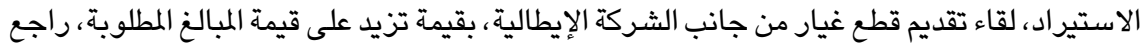

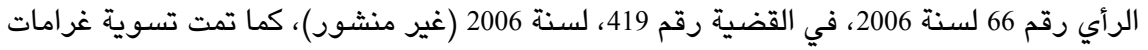

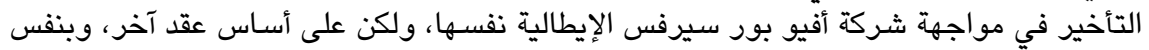

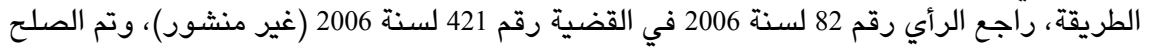

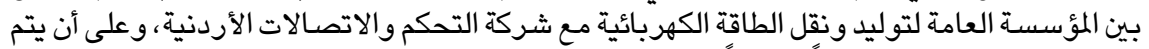

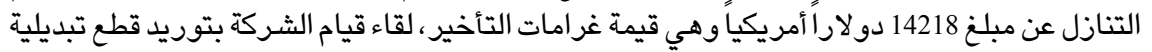

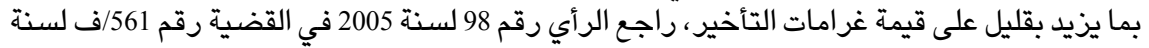

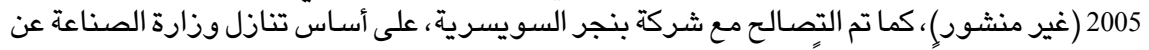

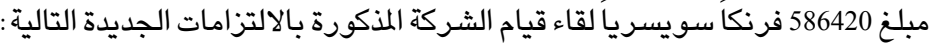

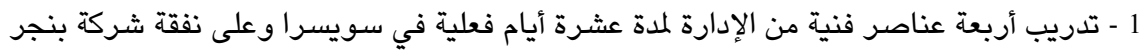

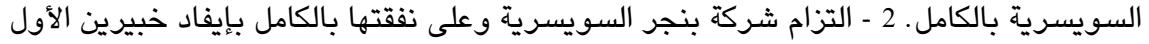

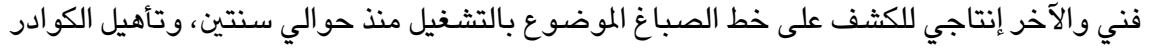
الإنتاجية العاملة على هذا الخط لمدة أسبوع. 3 - تلتزم شركة بنجر بتأمين قطع تبديلية بقيمة 120 ألف الف 
الدولة الفرنسي الذي يعد غرامات التأخير من النظام العام، ولا يمكن أن تكون محلاً للصلح، كما سيمر معنا لاحقاً.

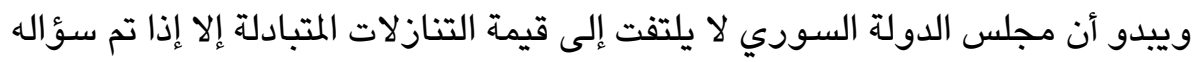

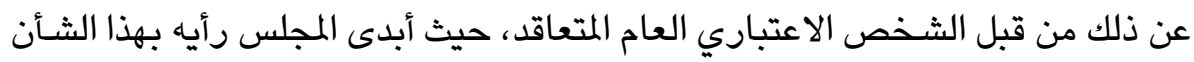

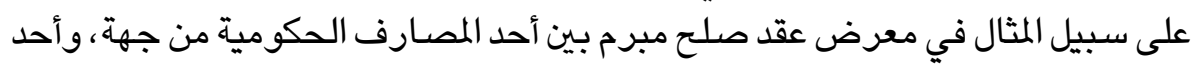
مدينيه بشأن نزاع حول عقد قرض، وضئ وبين رأيه في مقدار الفائدة واجبة الأداء من قبل المقترض (118).

كما اتخذ مجلس الدولة السوري أحياناً مواقف غريبة تجاه التنازلات المتبادلة وعلاقتها

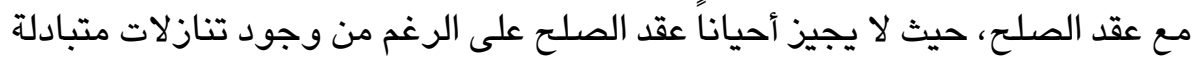

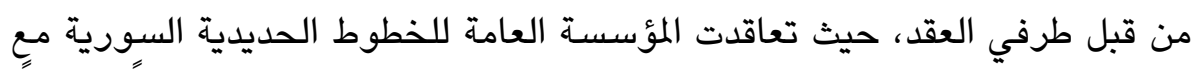

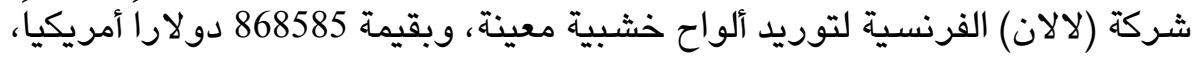

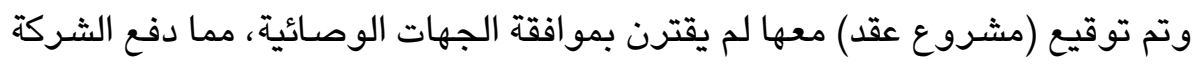

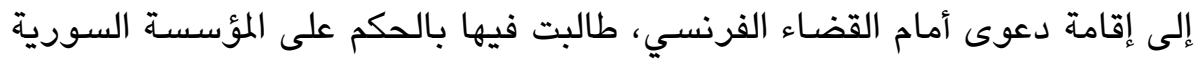

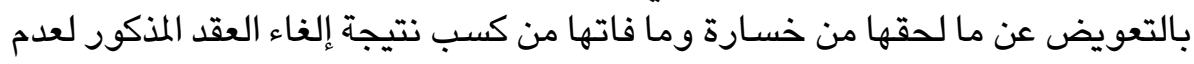

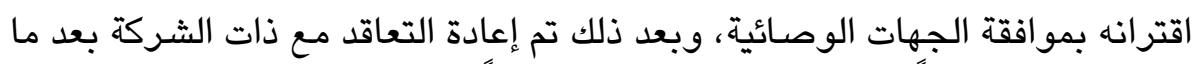

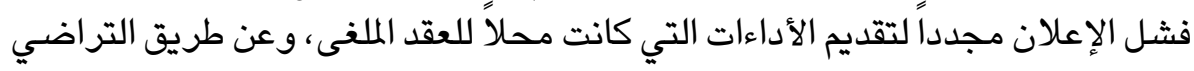

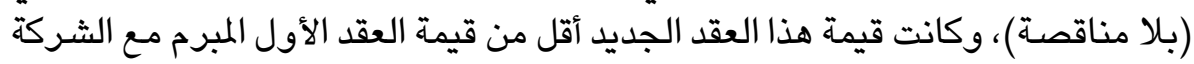

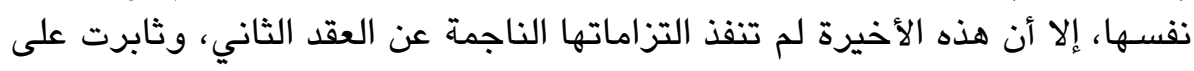

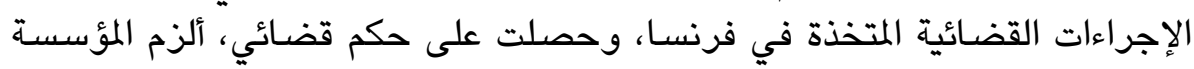

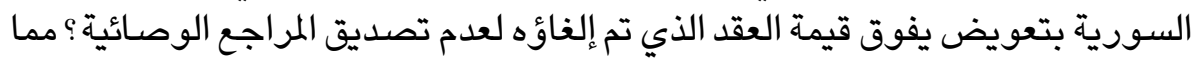

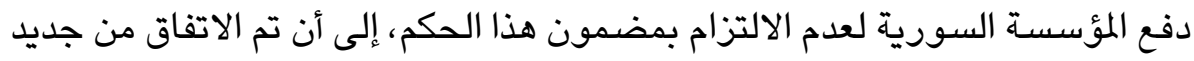

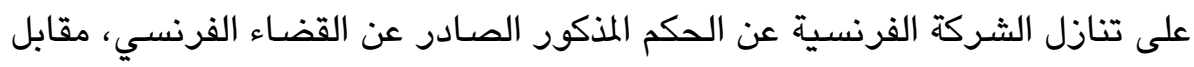

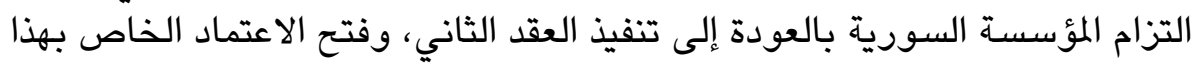

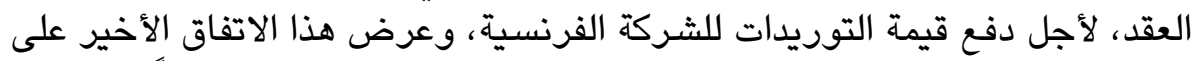

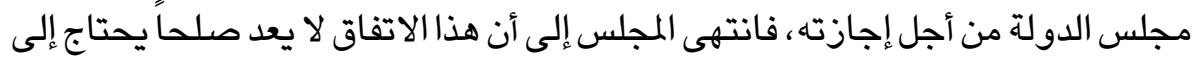

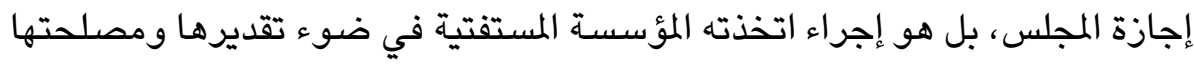

= فرنك سويسري. راجع الرأي رقم 177 لسنة 2005 في القضية رقم 638/ف لسنة 2005 (غير منشور)،

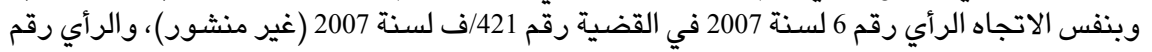

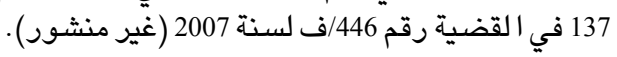
(118) رأي مجلس الدولة السوري رقم 10 لسنة 2008 في القضية رقم 418 لسنة 2008 (غير منشور). 
ودون أن يترتب عليها أعباء مادية(119)، ودون أدنى شك، فإن هذا الموقف من مجلسٍ

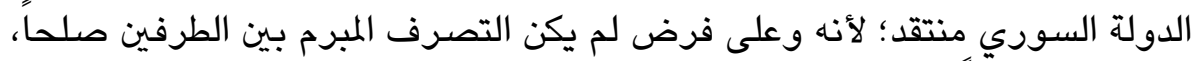

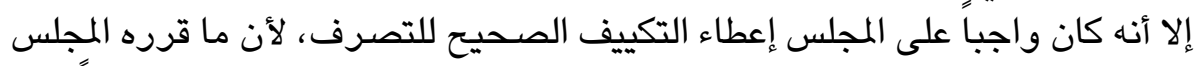

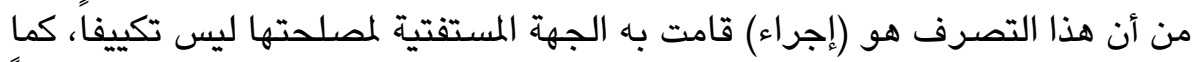

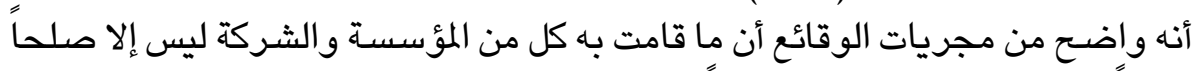

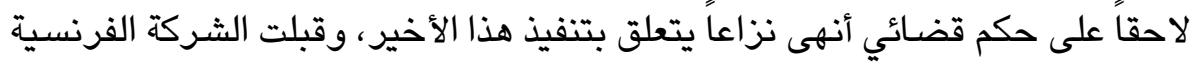

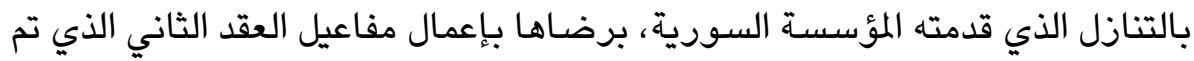

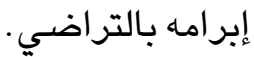
ومن جهة أخرى، فإن مجلس الدولة السوري أجاز تصرفات ليست في حقيقتها صلحاً،

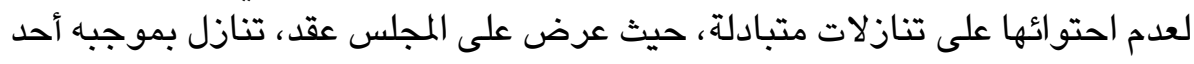

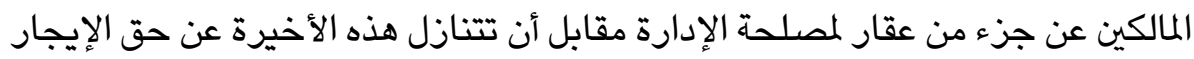

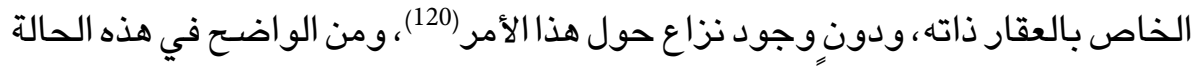

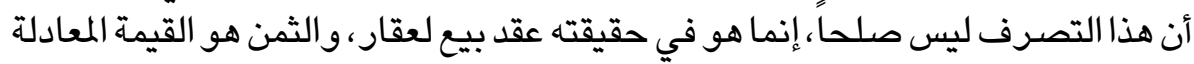
لحق إيجار العقار التجاري.

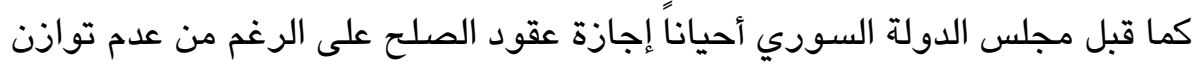

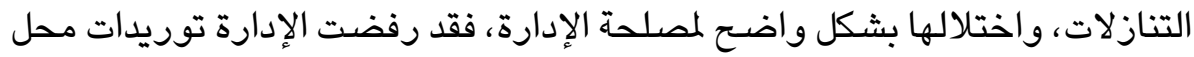

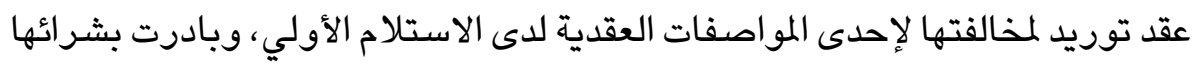

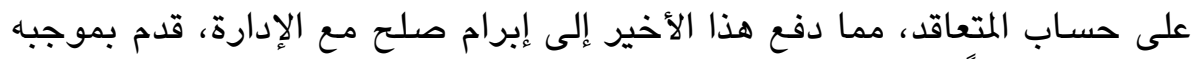

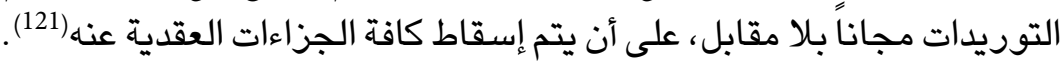

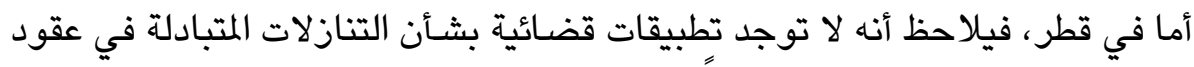

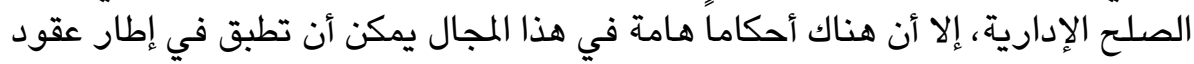

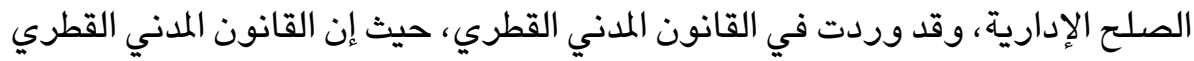

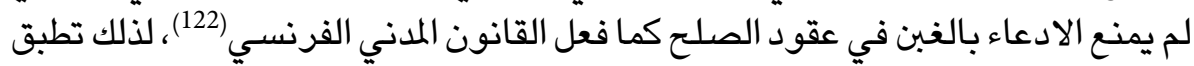

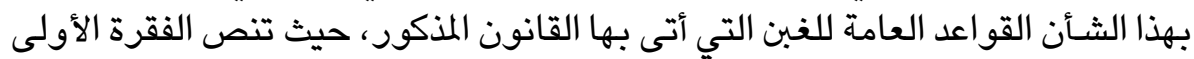

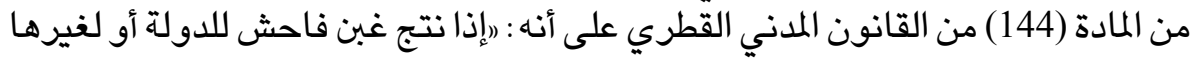
(119) راجع : رأي مجلس الدولة السوري رقم 219 لسنة 2003 (غير منشور). (120) راجع: رأي مجلس الدولة السوري رقم 199 لسنة 2007 في القضية رقم 617 /ف لسنة 2007، (غير

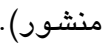

(121) راجع: رأي مجلس الدولة السوري رقم 175 لسنة 2005، في القضية رقم 634/ف لسنة 2005 (غير منشور). (122) (1اجع ما ورد ذكره في الهامش رقم 43. 
من الأشخاص الاعتبارية العامة أو لأحد عديمي الأهلية أو ناقصيها أو لجهة الوقف، جاز الوقاز

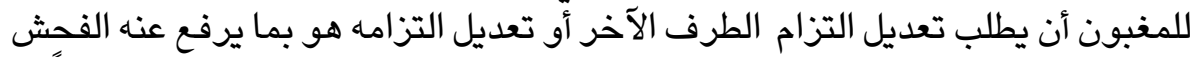

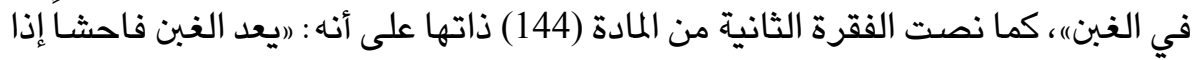

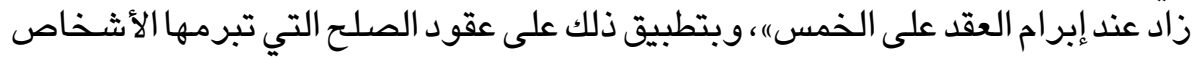

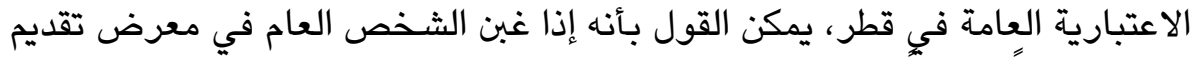

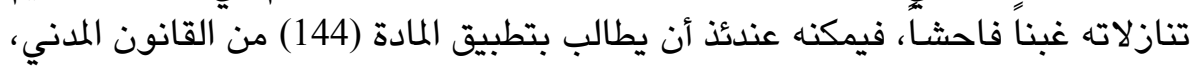

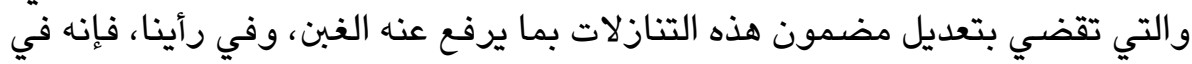

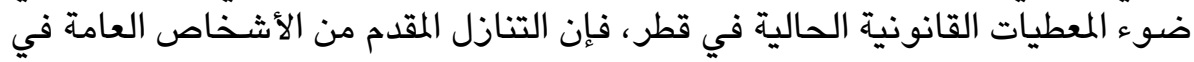

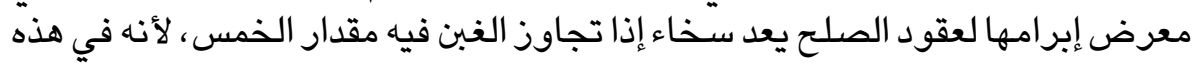
الحالة فقط يحق لهذه الأشخاص أن تطلب رفع الغبن. 


\section{المبحث الثاني \\ المحل المشروع: نطاق محل عقد الصلح الإداري \\ وفقا لمتطلبات النظام العام}

يجب أن يكون الصلح مشروعاً سواء أكان مدنياً أم إدارياً، وإن القاعدة العامة التي ينص عليها القانون المدني، والمتعلقة بضرورة توافق محل العقد مع مقتضيات النظام العام والآداب(123)، تطبق في مجال عقود الصلح الإدارية كما تطبق في مجال عقود

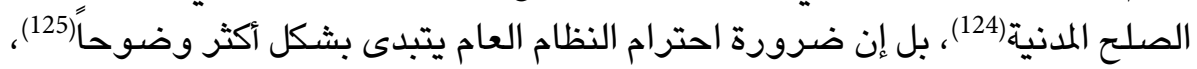
وخصوصية في إطار الصلح الإداري(126)، وهو ما ينتج عنه أولاً أن هناك مجالات مختلفة

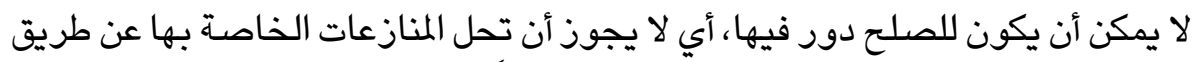

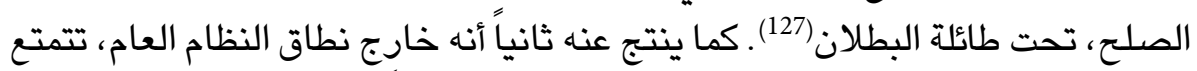
الإدارة بهامش من التحرك، ويمكنها أن تحل أي نزاع صلحاً (128)، وسوف نبحث في هذه نهات

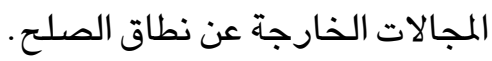

\section{المطلب الأول

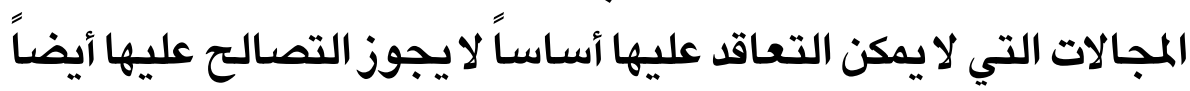

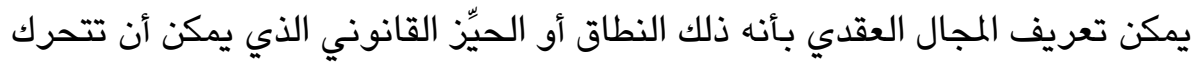

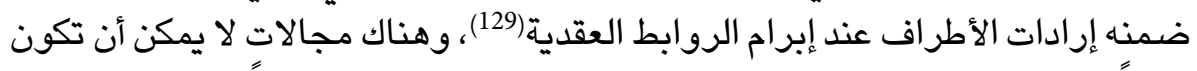

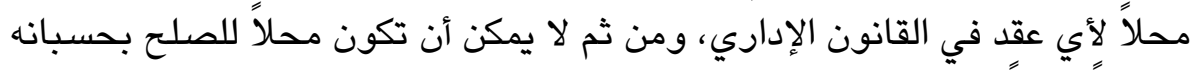

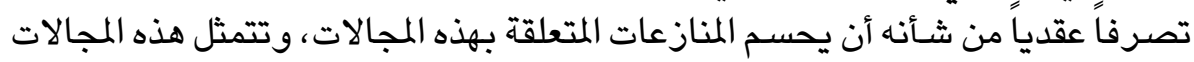

(123) راجع: المادة (6) من القانون المدني الفرنسي، والمادة (136) من القانون المدني السوري، والمادة (157)

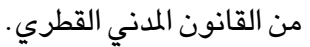

(124) Cornu.J, op.cit., p.49 et s. Chatelier L.G, Transaction, Répertoire de contentieux administratif, op.cit., n²9. Yolka Ph., op.cit., p.603.

(125) Le Chatelier L.G, Transaction, Répertoire de contentieux administratif, op.cit, n²9. Cornu J, op.cit, p. 42 et s.

(126) Hoepffner H., Droit des contrats administratifs, Dalloz, Paris, 2016, p. 485. Yolka Ph, op.cit., p.603. Rayssac R, op.cit., p.127.

(127) Le Chatelier. L.G., Transaction, Répertoire de contentieux administratif, op.cit, nº30. Rayssac R., op.cit., p.127.

(128) Rayssac R., Ibid, p.127.

(129) د. مهند نوح، الإيجاب والقبول في العقد الإداري، ط2، منشورات الحلبي الحقوقية، بيروت، 2013، ص51. 
أولاًِ- الاختصاصات الإداريتة:

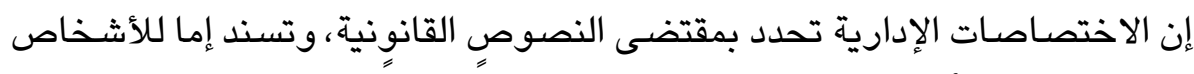

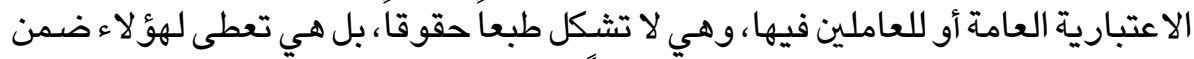

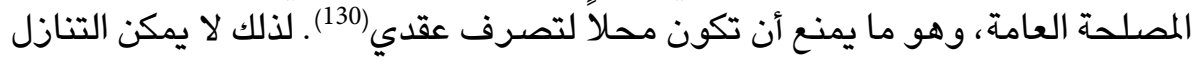

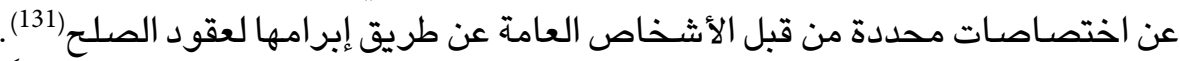

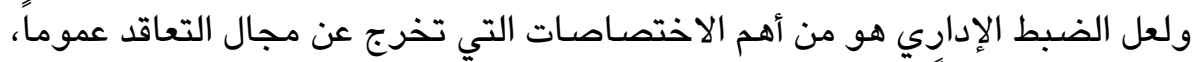

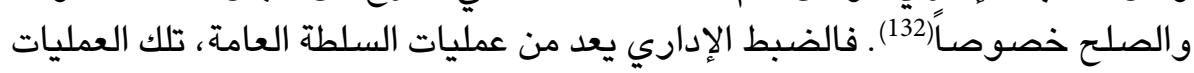

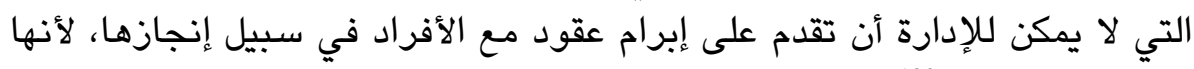

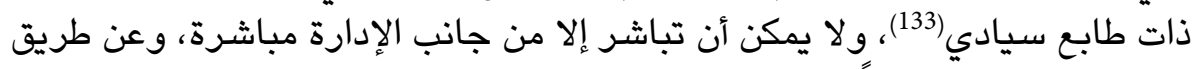

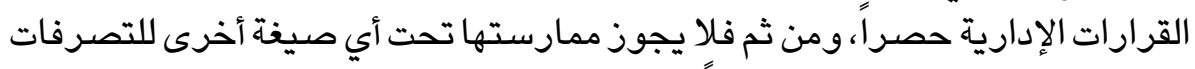

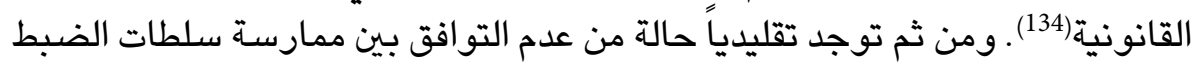
الإداري، والآليات التعاقدية(135). تومن تونيد.

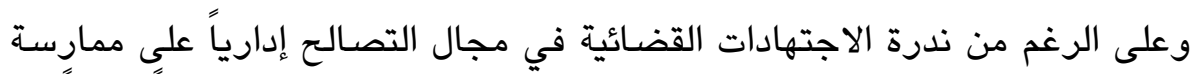

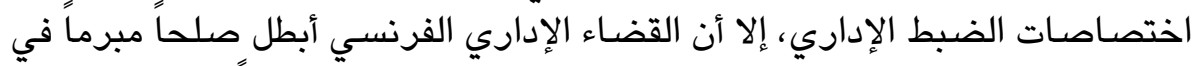

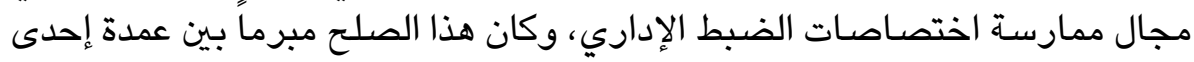

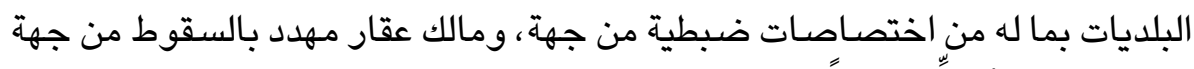

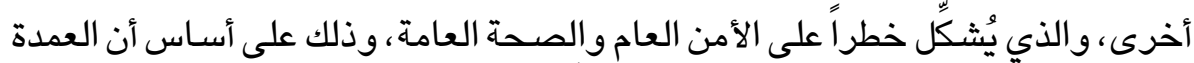

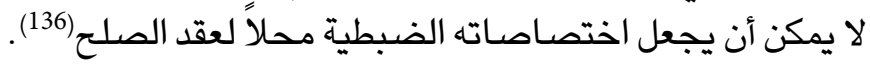

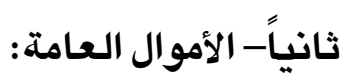

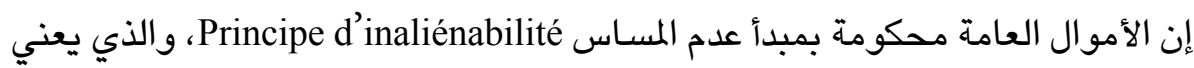

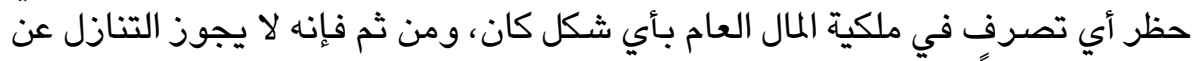

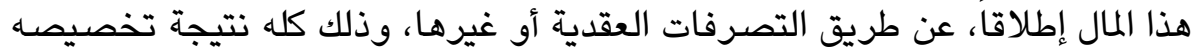

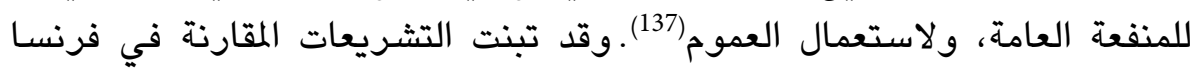

(130) Richer L., Droit des contrats administratifs, op.cit., p.124.

(131) Yolka.PH, op.cit., p.49 et s.

(132) Moreau J., Les « matières contractuelles »,AJDA, 1998, p.747.

(133) Moreau J., Ibid, p.747.

(134) Richer L., Présence du contrat en la police administrative, A.J.D.A, 1999, p.34.

(135) Richer L., Présence du contrat, Ibid, p.35.

(136) Conseil de préfecture de Lille; 18-5-1953, Maire de Moureaux contre Lagache, Cité par Rayssac R., op.cit., p.138 et Le Chatellier G., op.cit., $\mathrm{n}^{\circ} 30$.

(137) Gaudement Y., Traité de droit administratif, Droit administratif des biens, Paris, 2012, p.202. Godfrin. $=$ PH- Degoffe M., Droit administratif des biens, Paris, 2012, p.202. Auby.J.M - Bon.P -Auby.J.B- 


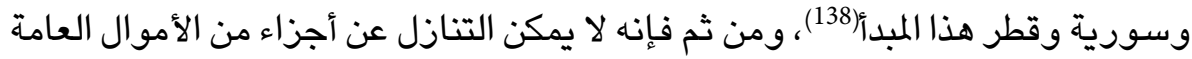

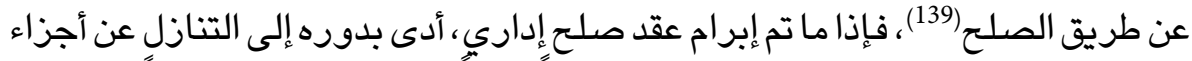

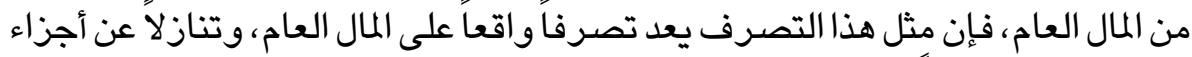
منه(140)، ويقع باطلاً( 141) .ولايجوز إبرام الصلّح بين الإدارة والغير في إطار تعيين حدود

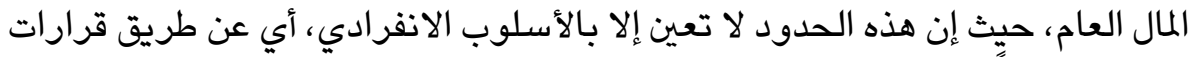

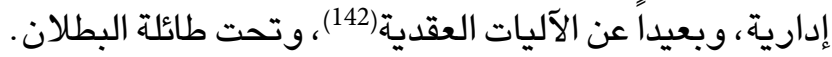

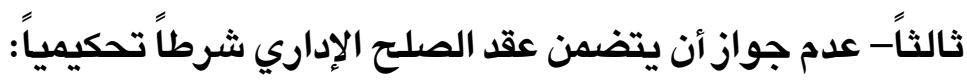
حيث لا يجوز لعقد الصلح الإداري أن يتضمن شرطاً تحكيمياً، ويقع ذلك ضمن الحظر

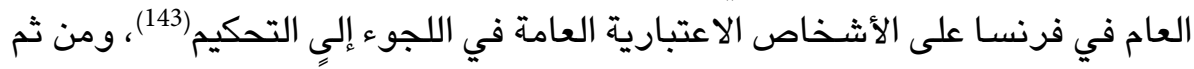

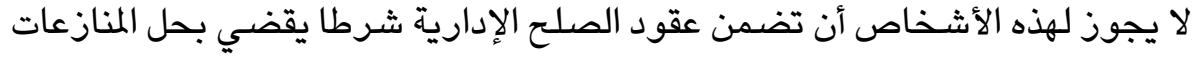

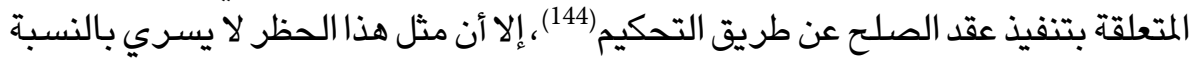

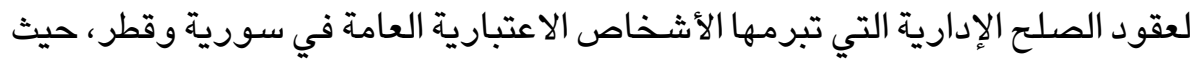

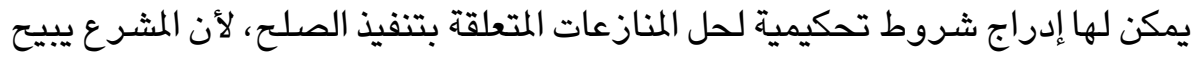

$=\quad$ Terneyre.PH, Droit administratif des biens, Dalloz, Paris, 2011, p.166.

وراجع في مفهوم عدم المسـاس خصوصـاً من الناحية التأصيلية : د. مهند نوح، الأموال العامة : جدلية العلاقة

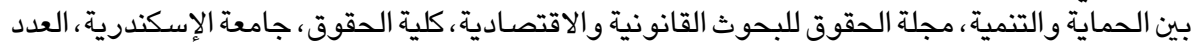

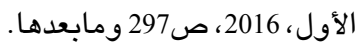
(138) راجع المادة (11311 (L-) من التقنين العام لملكية الأشخاص العامة الفرنسي، والمادة (1-1311) من التقنين العام للجماعات الإقليمية الفرنسي، والمادة الأولى من القانون رقم 10 لسنة 1987 القطري، والمئ والمادة (90) من

(139) Cornu J., op.cit., p.43. Yolka PH., op.cit., p.603. Le Chatellier G., Op.cit., n³0.

$$
\text { القانون المدني السوري. }
$$

(140) Gaudement.Y, Traité de droit administratif, op.cit., p.199 et.S. Godfrin.PH- Degoffe.M, op.cit., p.203. Auby J.M - Bon.P -Auby J.B-Terneyre PH, op.cit., p.12.

(141) C.E, 1-3-1989, Béro, D.adm.1989,nº 244.

(142) Godfrin.PH- Degoffe M, op.cit, pp.85-88. Auby J.M - Bon.P-Auby J.B-Terneyre.PH, op.cit., p.86. (143) يوجد الأسـاس التشـريعي لهذا الحظر في فرنسـا في المادة (2060) من القانون المدني الفرنسي المعدلة

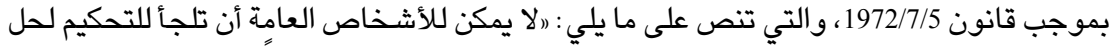

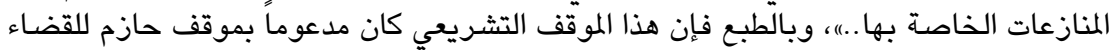

$$
\text { الإداري الفرنسي، راجع: }
$$

Laubadère A. - Delvolvé P. - Moderne F., Traité des contrats administratifs, T2, L.G.D.J, Paris, 1984, p.950. Braconnier S., Précis du droit des marchés publics, Le Moniteur, Paris,2007, p.450. Hoepffner H., op.cit., p.493. .Foussard D., L'arbitrage en droit administrative, A.J.D.A, R.arb, 1990, p.8-

ومن المعروف أن هناك حالات استثنائية يبيح فيها المشرع الفرنسي للأشخاص الاعتبارية العامة اللجوء إلى

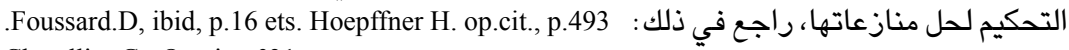
(144) Le Chatellier G., Op.cit.,n`31. 


\section{التحكيم في العقود الإدارية كأصل عام(145). رابعـاً- عدم جواز الصلـح على غرامات التأخير:}

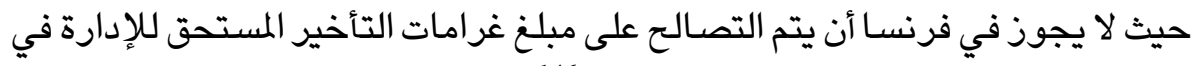

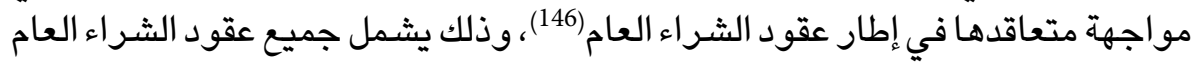
contrats des marchés publics

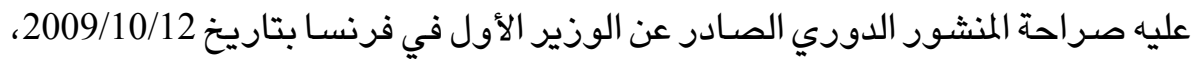

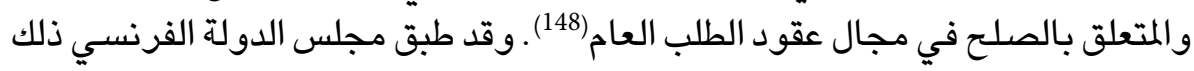

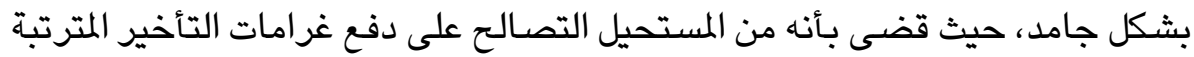

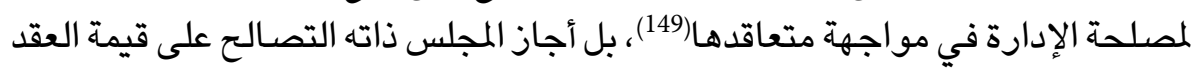

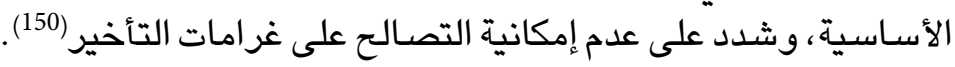

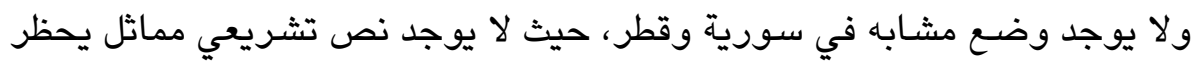

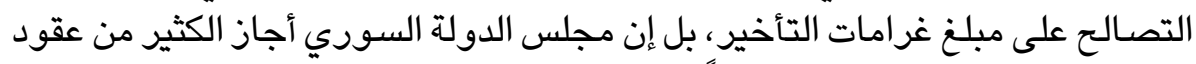

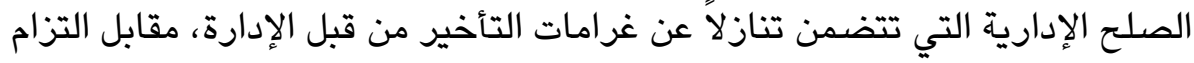

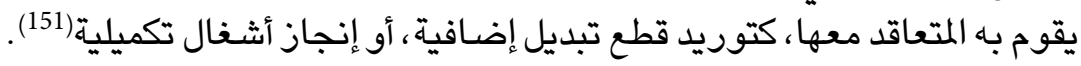

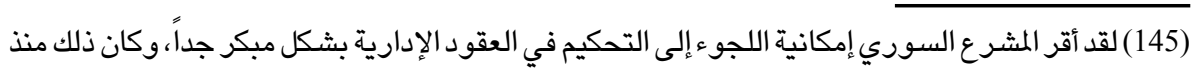

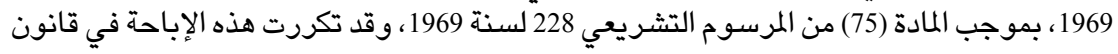

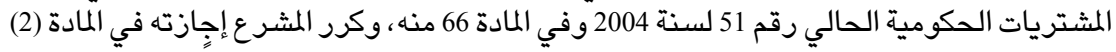

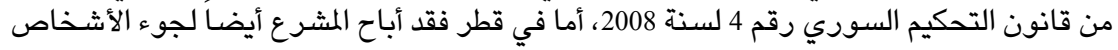

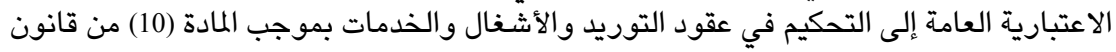

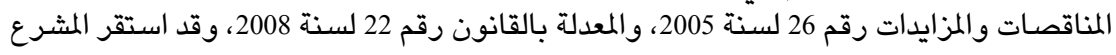

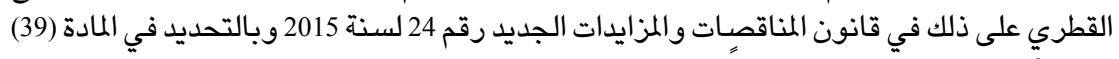

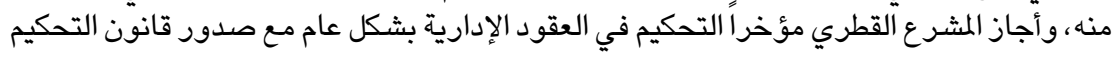

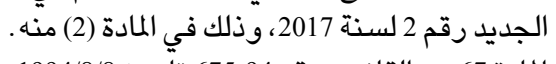

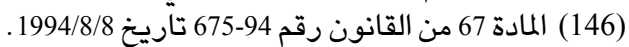

(147) Le Chatellier G., Op.cit., n³6. Yolka. PH., Op.cit., p.603. Dyens.S, Recourir à la transaction dans les collectivités territoriales, Droit Administratif ${ }^{\circ} 5$, Mai 2015, prat.5. Richer.L, Droit des contrats administratifs, op.cit, p.283. Hoepffner.H, op.cit, p.485.

(148) Linditch F., op.cit., p.2243.

(149) C.E, 17-10-2003, Min de l'intérieur - synd.intercom d'assainissement Le Beauset, Dr.adm, 2003, n²39.

(150) C.E, 10-11-2004, Entreprise Paul Millet, req n²56031.

(151) رأي مجلس الدولة السوري رقم 189 لسنة 2008 في القضية رقم 495 /ف لسنة 2008، (غير منشور)،

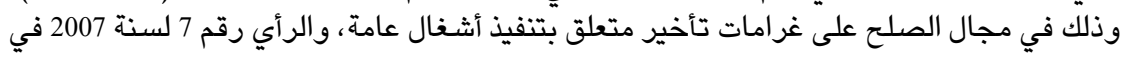

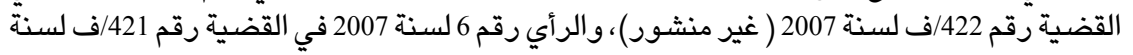
2007 ( غير منشور) بشأن الصلح على غرامات تأخير مترتبة على التأخير في تنفيذ عقود توريد. 


\section{خامساً - عدم جواز التصالح على المسؤولية العقدية:}

وهذه الحالة توجد في فرنسا، حيث لا يجوز للبلديات(152 أو المحافظات(153)، أن تتنازل

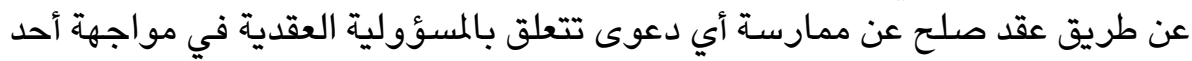

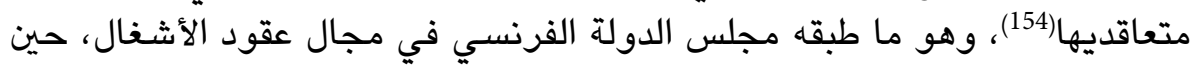

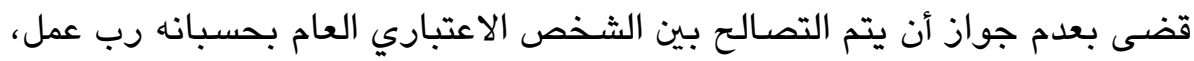

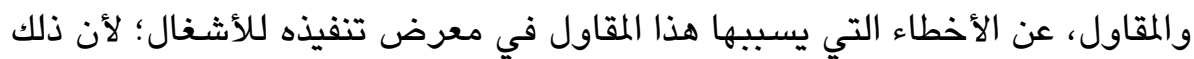

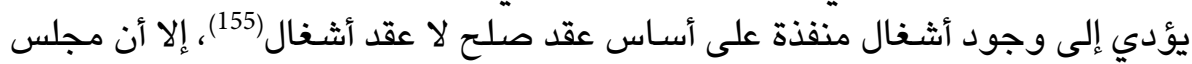

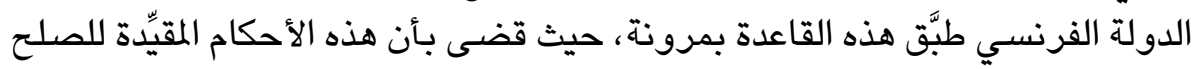

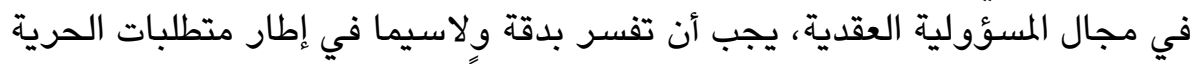

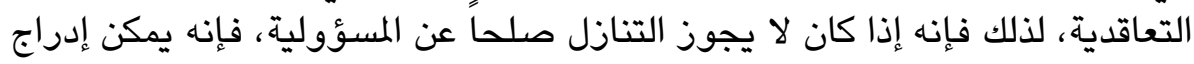

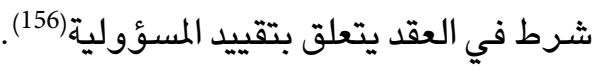

\section{المطلب الثاني}

\section{عدم جواز إبرام عقود الصلّح الإداريته في مجال المشروعية الإدارية}

من حيث المبدأ يتمتع كل شخص بـ بالحرية في الامتناع عن رفع دعوى الإلغاء في مواجهة

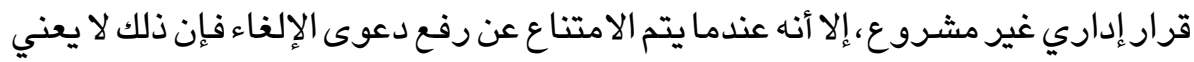

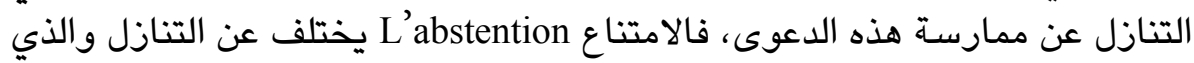

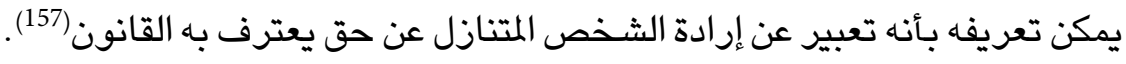

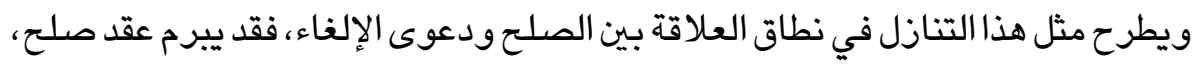

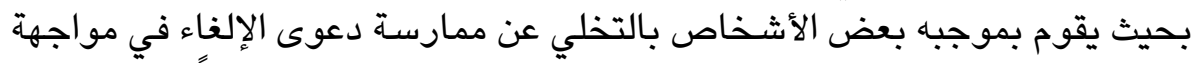

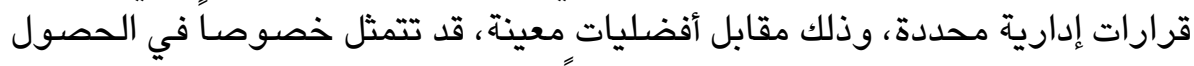

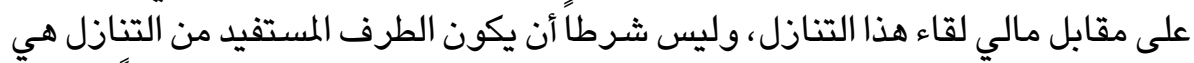

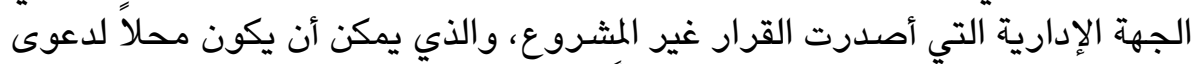

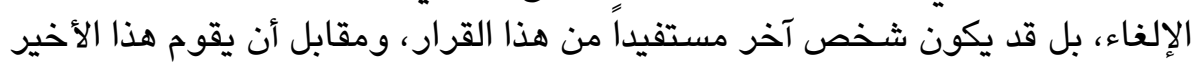

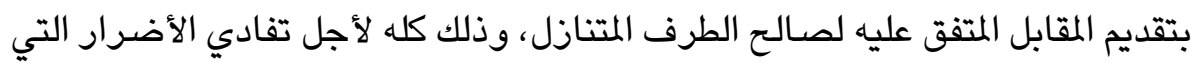

(154) Le Chatellier G., Op.cit., $n^{\circ} 38$.

$$
\begin{aligned}
& \text { (152) المادة ل.1231 - } 10 \text { من التقنين العام للجماعات الإقليمية الفرنسي. }
\end{aligned}
$$

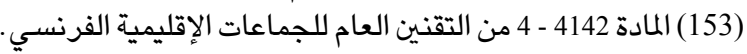

(155) C.E, 22-7-1992, Société national de construction, D, 1993, Somm, p.202, obs, Terneyre.

(156) C.E, 28-1-1998, Sté Borg Warner, R., p.20.

(157) Alhama F., Transaction et renonciation à l'exercice du recours pour excès de pouvoir, RFDA, 2017, p.503. 


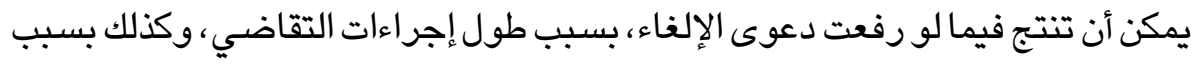

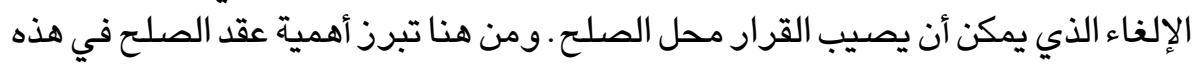

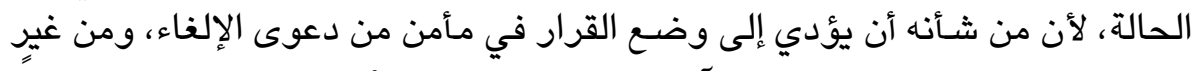

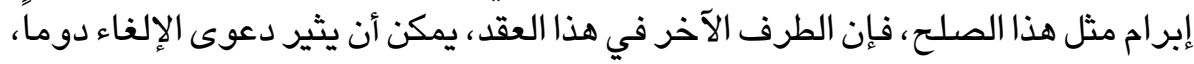
إن لم يتنازل عن ممارسة دعوى الإلغاء في مواجهة هذا لمذا القرار (158).

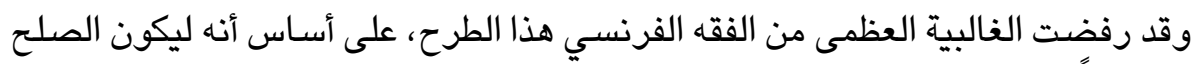

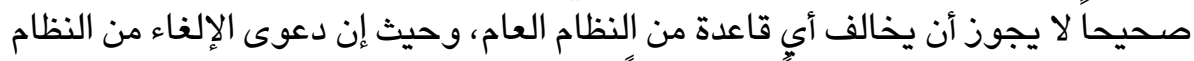

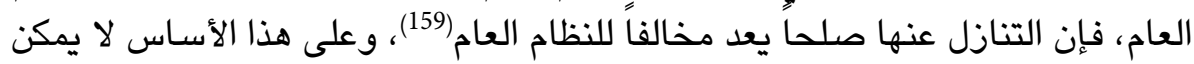

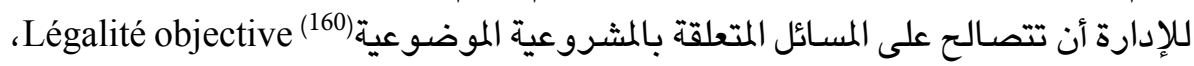

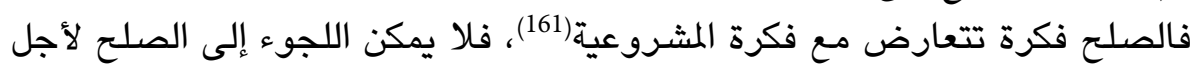

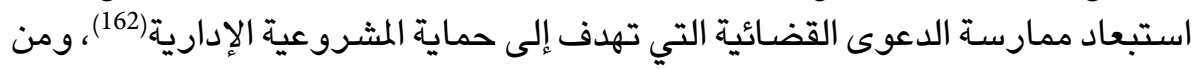

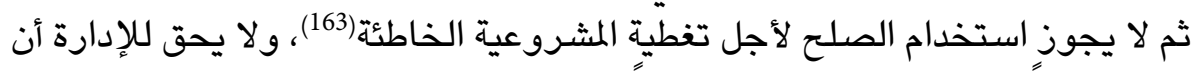

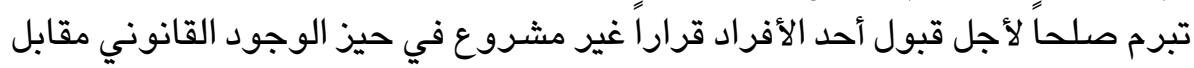

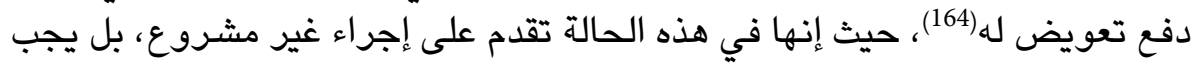

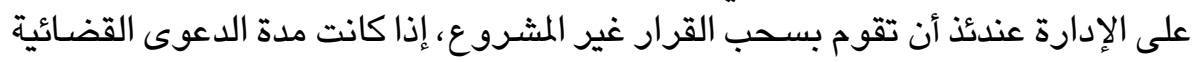

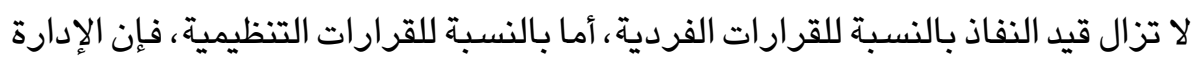
تستطيع إلغاءها في كل وقت (165).

ويؤكد جانب من الفقه الفرنسي ذلك على أساس أن التقنية الصلحية القائمة على

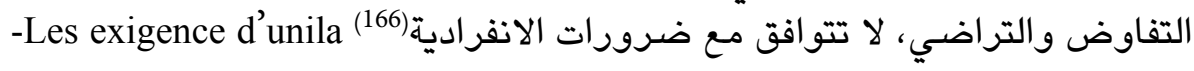
téralité

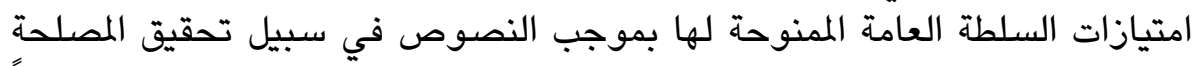

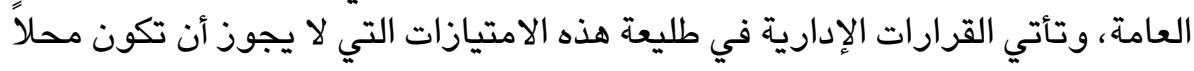

(158) Alhama F., ibid, p.503.

(159) Alhama F., ibid, p.510. Chapus R., Droit du contentieux administratif, Montchrestien, Paris, 2008, p.132.

(160) Hoepffner H., op.cit., p.493.

(161) Florence N., Impossibilité de renoncer par transaction à exercer le recours pour accès de pouvoir, Droit admin, $\mathrm{n}^{\circ} 1$, Janvier, 2008, com8. Lyon-Caen A., op.cit., p.48.

(162) Chapus R., op.cit., p.956.

(163) Florence N., op.cit., com8.

(164) Yolka P., op.cit., p.603.

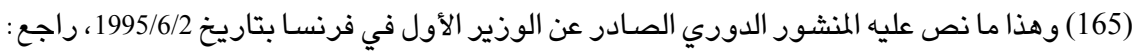
Le Chatellier G., Op.cit., n³3. Yolka PH., Op.cit., p.603. Cornu J., Op.cit., p.44. Rayssac Rj, Op.cit., p.134.

(166) Florence.N, op.cit., comm.8. 
لتصـرف تعاقدي صلحي(167)، وإن عدم جواز التصـالح على المسـائل المتعلقة بالمشـروعية هو الذي يحظر في الوقت نفسـه عدم جواز تتازل الفرد عن حقه في رفع دعوى الإلغاء

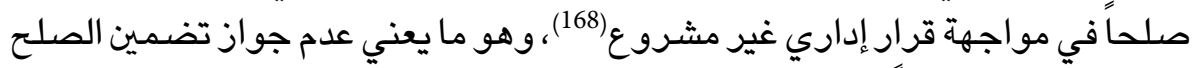

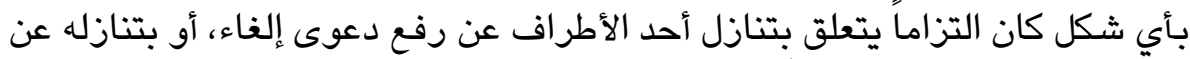

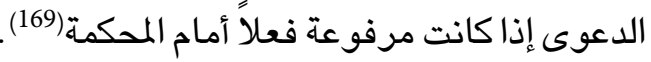

وعلى الرغم من أن هناك حكماً قديماً لمجلس الدولة الفرنسي، قبل بموجبه تنازل أحد

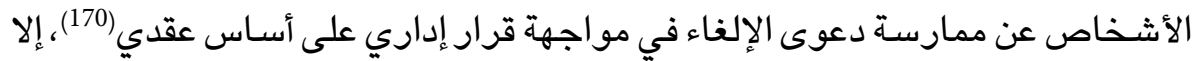

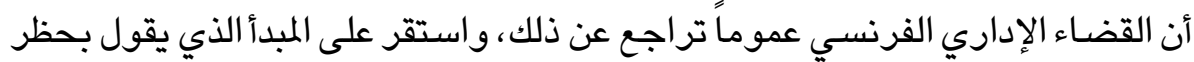

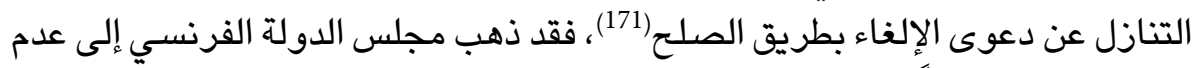

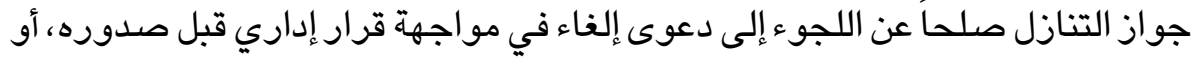
قبل نفاذه(172)، بمعنى أنه لا يجوز التنازل عن دعوى الإلغاء في مواجهة قرار إداري قبل أن يتحقق وجوده القانوني، مما فسره بعض الفقه بمفهوم المخالفة أنه يمكن التصـالح على عدم اللجوء إلى دعوى الإلغاء إذا تحقق الوجود القانوني للقرار الإداري بصدوره ونفاذه(173).

وقد تم تبرير مبدأ حظر التصالح على التنازل عن دعوى الإلغاء على أسـاس الطبيعة

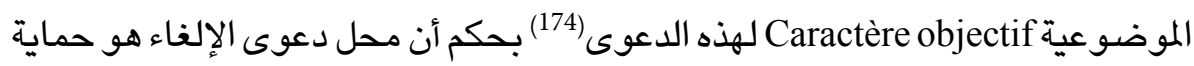
المشروعية، وليس حماية الحقوق الذاتية(175) Les droits subjectifs؛ ولأن اللجوء إلى اليى هذه الدعوى يعد من المبادئ العامـة للقانون(176)، وأن التنازل عن ممارستها يعد إخلالاً بقواعد النظام العام(177). كما أن حظر التنازل عن دعوى الإلغاء ييرر كون الحق في هذه

(167) Yolka P., Op.cit., p.603. Le Chatellier G., Op.cit., n³2.

(168) Rayssac R., Op.cit., p.133. Yolka PH., Op.cit., p.603. Le Chatellier G., Op.cit., n³4. Florence N., Op.cit., comm.8.

(169) Florence N., Ibid, comm.8.

(170) C.E, sect., 29 mars 1935, Pérignon et a., (a contrario), Lebon p.410; S., 1936, III, p.97, note. Alibert. R

(171) Alhama F., Op.cit, p.504.

(172) CE, 13 févr. 1948, Louarn, Lebon p.79. CE, 19 nov. 1955, Andréani, Lebon p.551 ; RPDA 1956. 25, concl. P. Landron.

(173) Alhama F., Op.cit, p.504.

(174) C. E, Ass. 19-11-1955, Sieur Andréani, R.P551. C.E, 2-2-2996, Sté établissement Crocquet, $\mathrm{n}^{\circ} 152406$.R.P26.

(175) CAA Paris, 30 déc. 1996, ,Boyer, Lebon T. p. 1073 ; JCP juin 1997, n² 26, II, 22871, p. 313, note Haïm.V.

(176) T.A, Amiens, 14-4-2007, n040087, A.J.D.A, 2007, 2013.

(177) T.A, Amiens, 14-4-2007, précité. T.A, Strasbourg. 21-6-2011, Knoerr et adam, req.n7005307. 
الدعوى يعد مبدأ ذا قيمة دستوريةة(178)، وفقاً لما قرره المجلس الدستوري الفرنسي(179)،

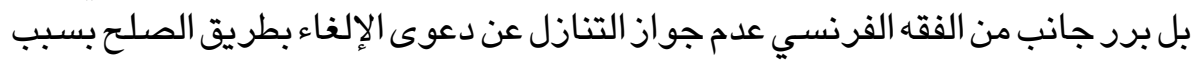
تاريخي يتمثل في أن هذه الدعوى تعد حجر الزاوية في القانون الإداري الفرنسي (180. وتطبيقاً للحظر المذكور، فقد تواترت أحكام القضـاء الإداري الفرنسي التي تقبل دعوى

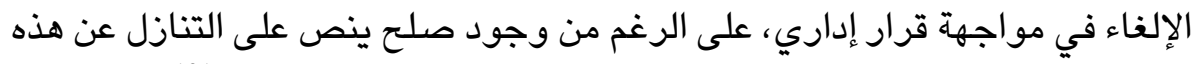

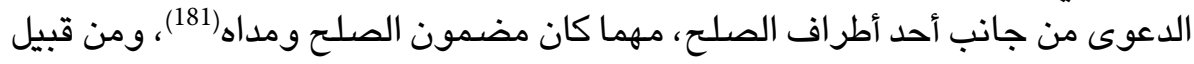

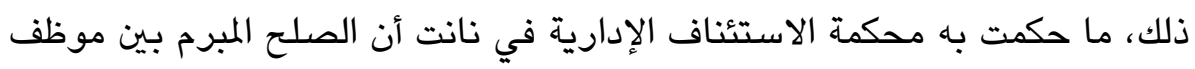

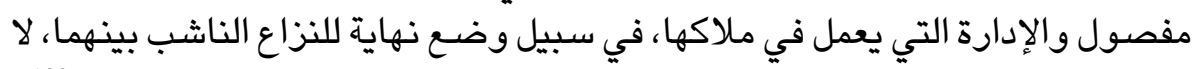

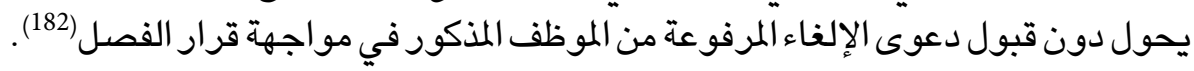

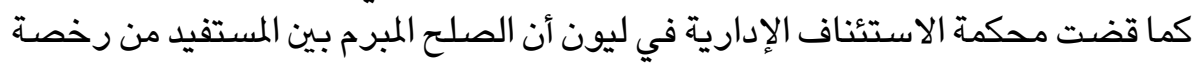

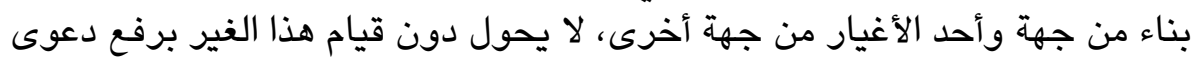

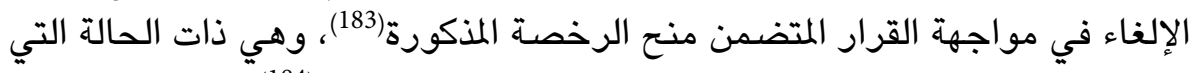

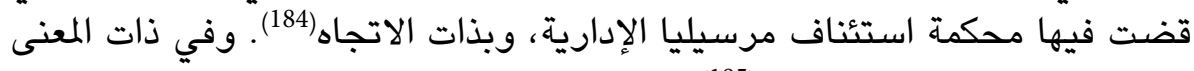
ذهبت الكثير من المحاكم الإدارية(185).

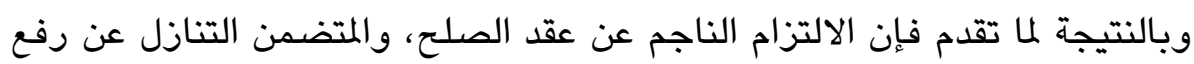

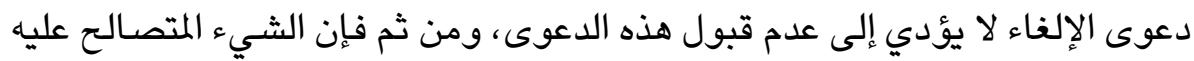
لا يعد عندئذ حجة على الأطراف Le chose transigée

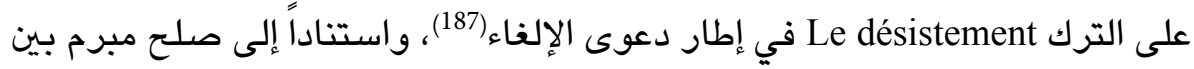

(178) Florence.N, Op.cit, comm.8. Le Chatellier.G, Op.cit, $n^{\circ} 34$.

(179) C.C, 9-4-1996, Dec.nº6-373, Statut d'autonomie de la Polynésie Français, R, 1996, p.43. C.C, 21-1-1994, Dec.n ${ }^{\circ} 93-335$, Urbanisme et construction, R, 1994, p.40.

(180) Merenne S., La transaction portant sur un recours pour excès de pouvoir, AJDA, 2015, p.993.

(181) Alhama F., op.cit, p.505.

(182) CAA Nantes, 25 mars 1999, Chambre de commerce et d'industrie du Mans et de la Sarthe.

(183) CAA Lyon, 19 févr. 2008, Baillet, nos 06LY00104, 06LY00105 et 06LY00106,

(184) CAA Marseille, 6 oct. 2016, Société Océanis promotion, n 13MA03759.

(185) فقد ذهبت المحكمة الإدارية في Cergy-Pontoise أن الصلح المبرم بين شركة مدنية للاستثمار الزراعي

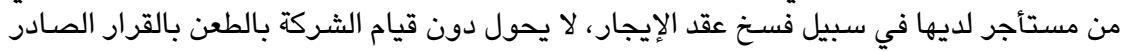

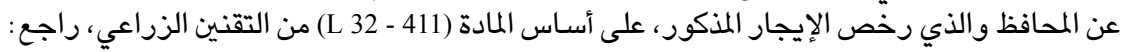

TA Cergy-Pontoise, 1er juill. 2011, nº 0912515, SCEA Bolle fils

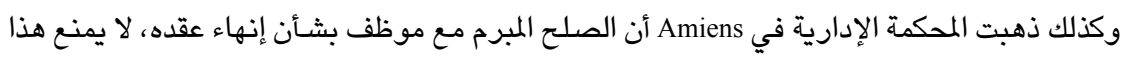

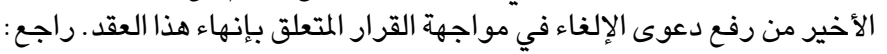

TA Amiens, 24 avr. 2007, n 0400871, Raskin, Dr. adm. janv. 2008, 8, comm. F. Nicoud ; AJFP 2008. 54 (186) Chapus R., op. cit., p.390. Alhama F., op.cit, p.505.

(187) الترك يعني اتفاق أطراف الدعوى على وضـع نهاية لها، ومن ثم فإنه يؤدي إلى النزول عن الدعوى، 


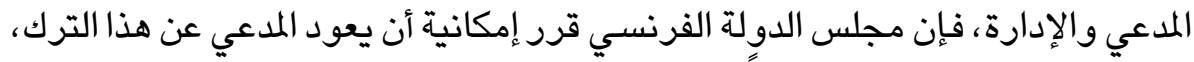

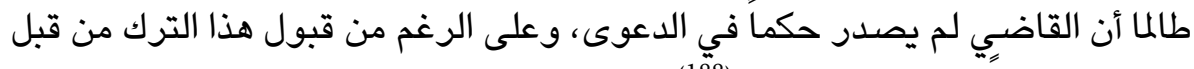
الإدارة استناداً إلى الصلى لمانح المذكور (188).

ونتيجة لما تقدم يلاحظ أنه عندما يكون هناك تنازع بين المنطق العقدي (المتعلق بالقوة

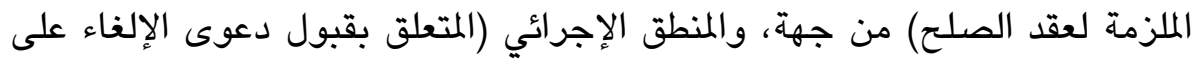

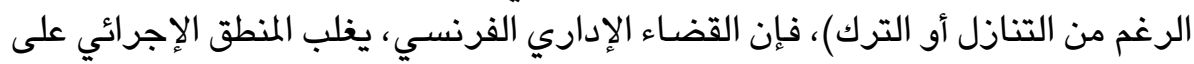

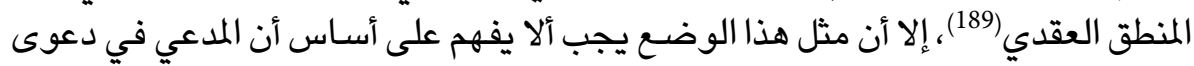

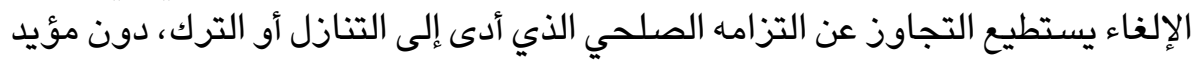

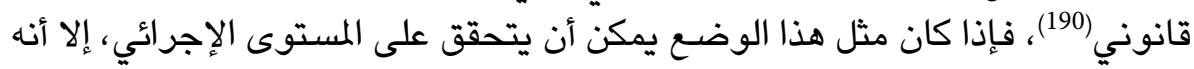

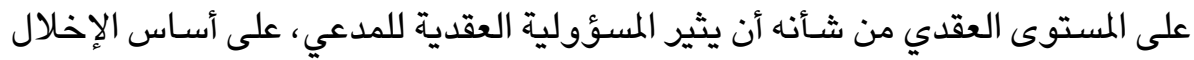
بالتزاماته الناجمة عن عقد الصلح (191).

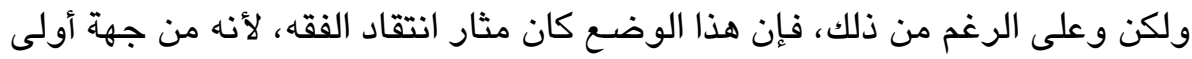

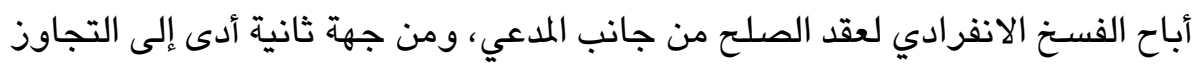

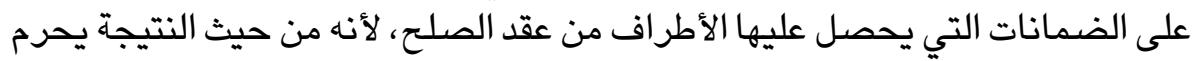
الصلح من أي فعالية (192).

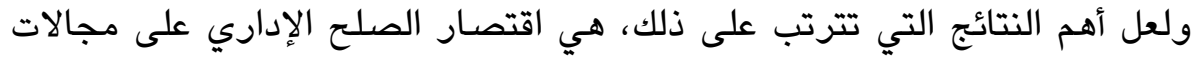

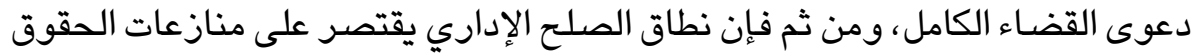

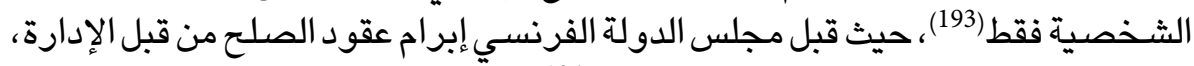

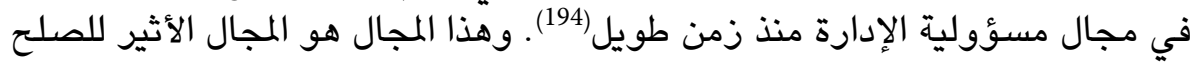

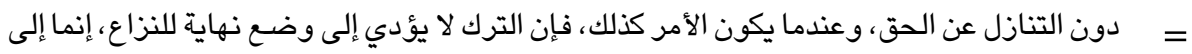

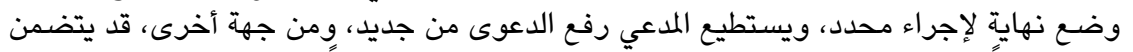

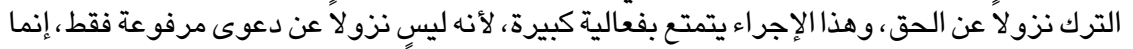

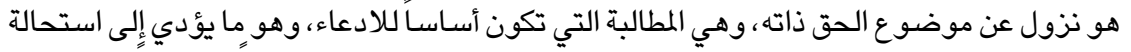

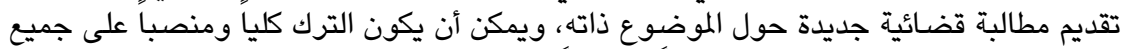

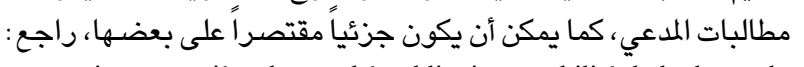

Terneyre Ph., Désistement et transaction en matière de marché public: irrecevabilité de la demande en ré.paration des fautes commises dans les travaux de réfection, D, 1993, p.202

(188) CE, 21 avr. 1944, Société Dockès frères, R.p.120.

(189) Alhama F., Op. cit, p.508.

(190) Alhama F., Ibid, p.507.

(191) Alhama F., Ibid, p.507.

(192) Alhama.F, Ibid, p.508.

(193) Florence, Op.cit., comm.8.

(194) C.E, 9-11-1949, Maraquis, R.P470. 
الإداري، وسواء أكانت هذه المسؤولية قائمة على أسـاس الخطأ، أم على الخطر ، أم على

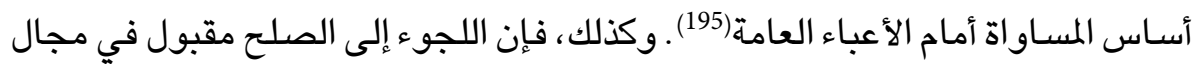
المنازعات المتعلقة بتنفيذ العقود الإدارية(196) ولاسيما في إطار عقود الأشغال العامة (197)،

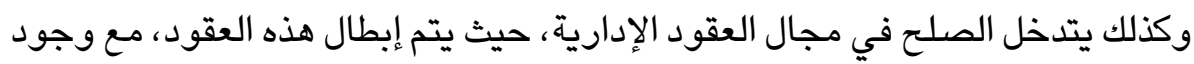
أداءات تعاقدية منفذة من قبل المتعاقد في العقد الباطل(198)، حيث يتم التصـالح مـع هذا المتعاقد على أسـاس تعويضـه عن النفقات النافعة التي أنفقها فقط، على أرضية الإثراء

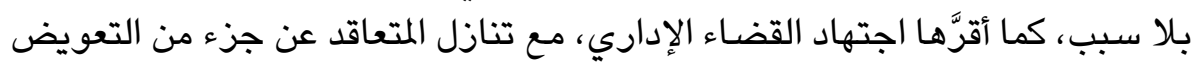

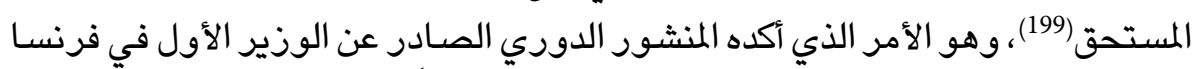
بتاريخ 2009/10/12(200)، وعلى أن تؤخذ بالحسبان دوماً المسؤولية التقصيرية المتعلقة بالخطأ الصـادر عن الإدارة أو متعاقدها، والذي أدى إلى بطلان العقد (201)، وذلك كعامل

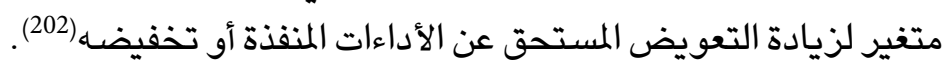

وعلى الرغم من هذا الموقف الواضـح للقضـاء الإداري الفرنسي في إطار عدم جواز التنازل

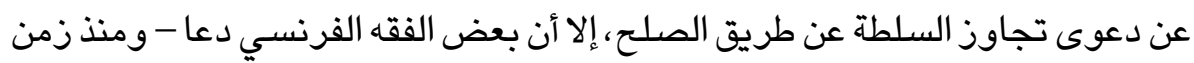

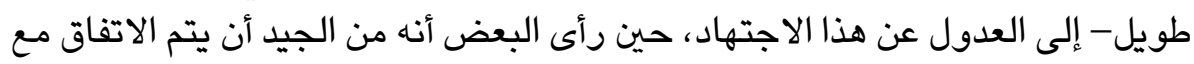

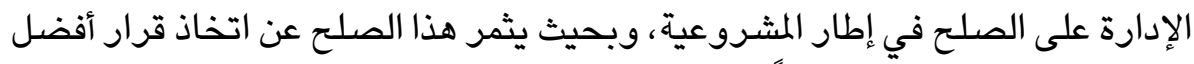

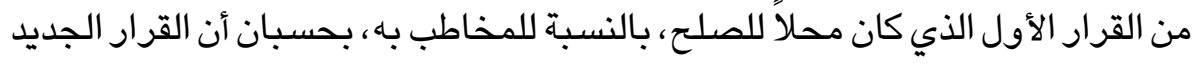
الناجم عن الصلّ سيضر بمصالحه بشكل أقل (203).

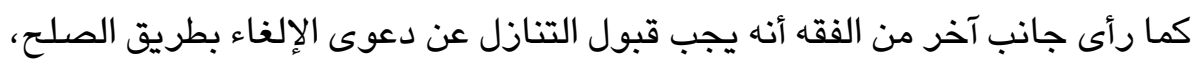
بالنظر الى التطورات التي أحاطت بكل من دعوى الإلغاء ودعوى القضـاء الكامل،

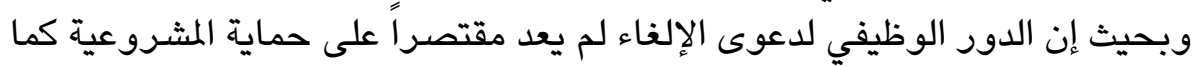

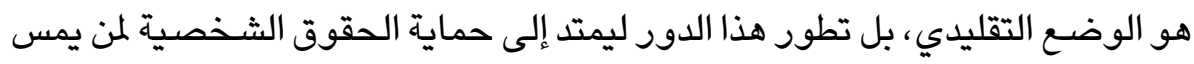

(195) Rayssac R., Op.cit., p.128.

(196) C.E, 4-10-1968, Commune de Saint - Germain -pré- Herment, R.P1002.

(197) Rayssac.R, Op.cit, p.130.

(198) Soler-Couteaux et Jean-Jacques. L, Op.cit, chron. 2. Rayssac.R, op.cit, p130.

(199) C.E, 23-5-1979, Che Fonknay - Le-Fleury.R.P226.

(200) Linditch F., op.cit, p.2244.

(201) Rayssac.R, op.cit, p.130. Soler-Couteaux et Jean-Jacques. L, Op.cit, chron. 2.

(202) C.E, 23-5-1979, Che Fontenay -Le- Fleury,R.P226.

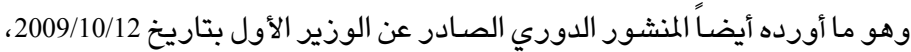

$$
\begin{aligned}
& \text { راجع: وهو مأورده }
\end{aligned}
$$

(203) Honorat J. - Baptiste.E, Chronique sous. C.E, 23-6-1989, A.J.D.A, 1989, p.424. 
القرار محل الإلغاء مراكزهـ القانونية، مما أدى بدوره إلى طبع دعوى الإلغاء بالطابع

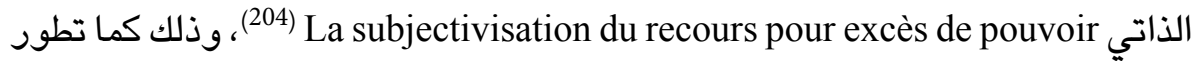
دور دعوى القضـاء الكامل، والذي امتد ليشـمل حماية المشروعية، مما أدى إلى اتسام

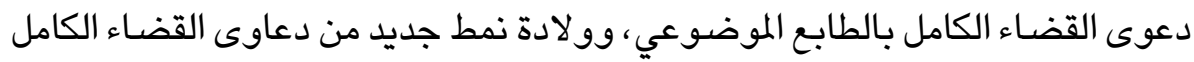

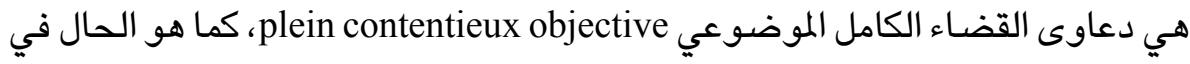
دعاوى إلغاء العقود الإدارية لعدم المشروعية، وهي الدعوى التي يمكن التنازل عنها

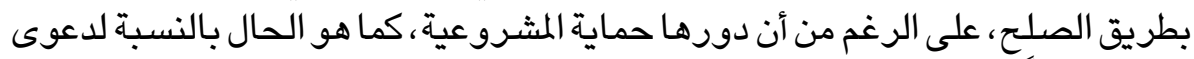

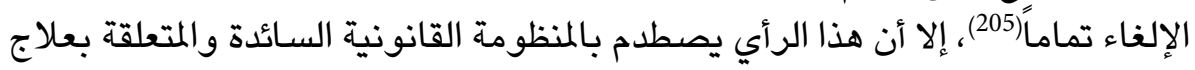

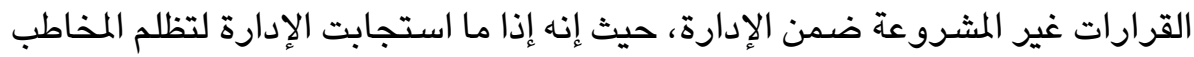

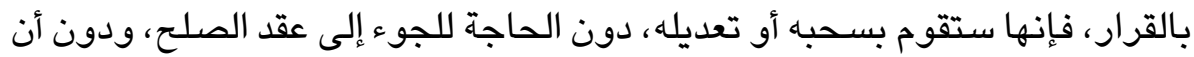
تطلب الإدارة أي مقابل لقاء ذلك(206).

ولعل مجال رخص البناء والهرم، هو المجال الأكثر اتسـاعاً لفرضية الصلح على التنازل

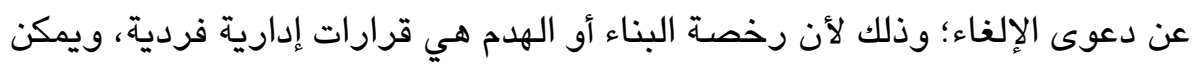

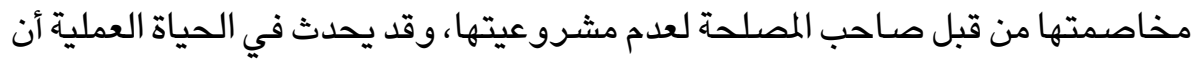

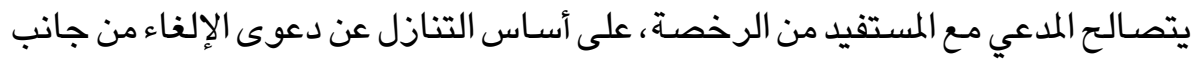

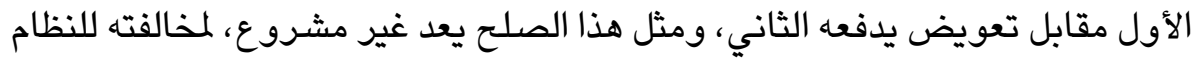

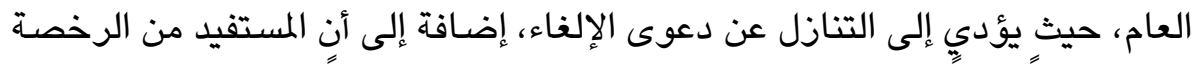

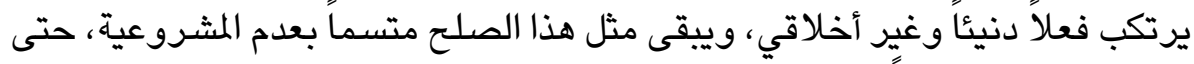

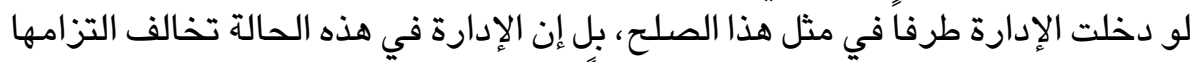

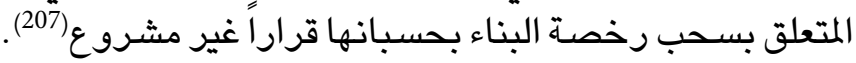

ولكن على الرغم من ذلك، فقد حدث في فرنسـا تطور تشـريعي هام حديثاً في مجال

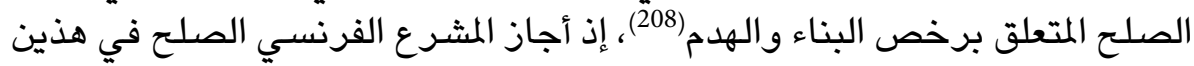

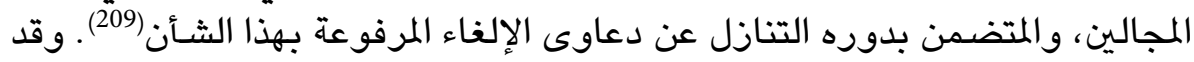
بدأ الاجتهاد القضـائي الإداري يسير في هذا الاتجاه، حيث أجازت المحكمة الإدارية

(204) Sirinelli.J, La subjectivisation du recours pour excès de pouvoir, RFDA, 2016, p.529.

(205) Alhama F., op.cit., p.510.

(206)Rayssac R., op.cit., p.134.

(207) Rayssac R., Ibid, p.135.

(208) Merenne S., op.cit, p.995.

(209) وقد أوجد المشـرع الفرنسي هذا الحكم التشـريعي وفقاً لأمر 2013/7/18، والذي أدرج المادة (600 -8 (L) في تقنين التظيم العمراني Code de l’urbanism، راجع: Merenne.S, Op.cit, p.995. Alhama.F, Op.cit, p.510. 
صلحاً يتضمن تنازلاً عن دعوى إلغاء تتعلق برخصـة بناء(210.

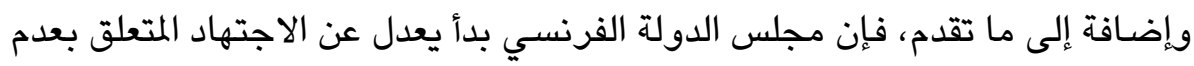

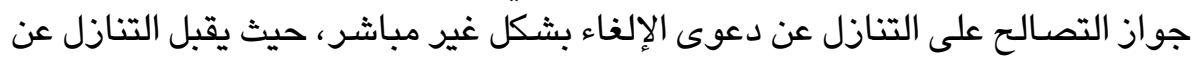

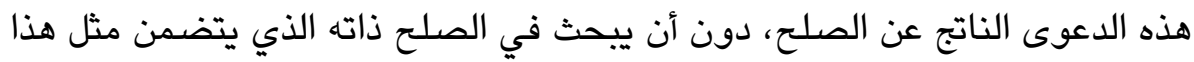

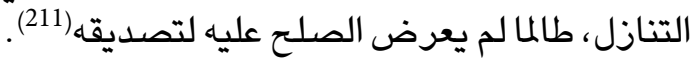

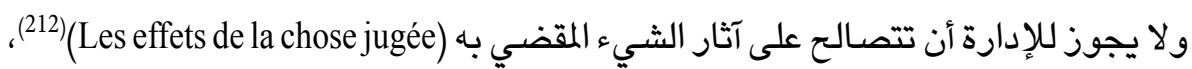

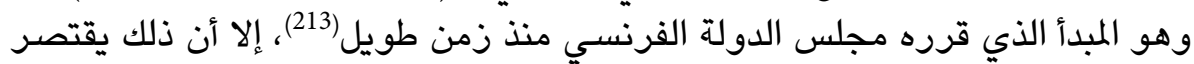

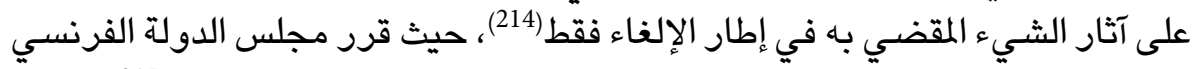

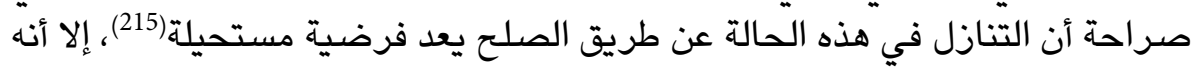

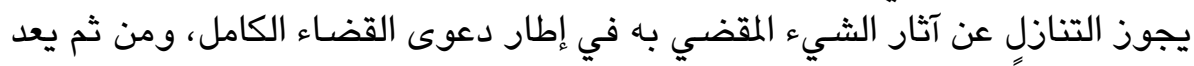

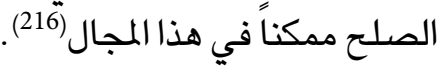

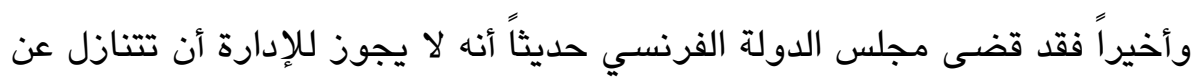

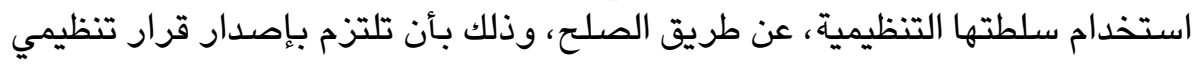

(210) تتلخص وقائع هذه الدعوى في أن بلدية Montrouge رفعت دعوى أمام المحكمة الإدارية في Mein لإلغاء

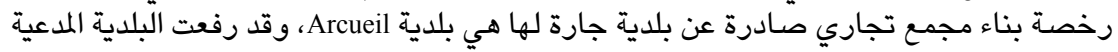

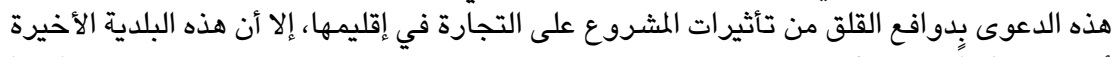

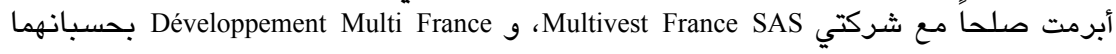

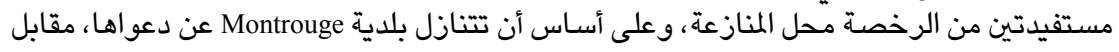

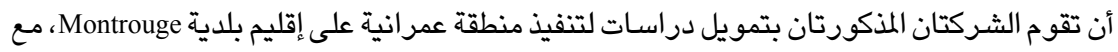

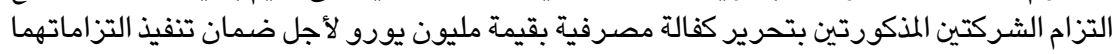

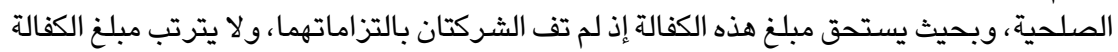

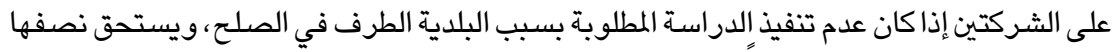

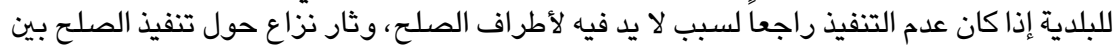

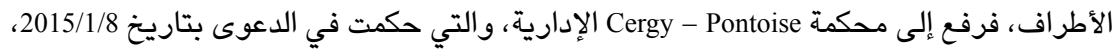

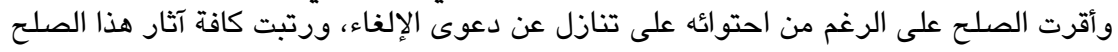

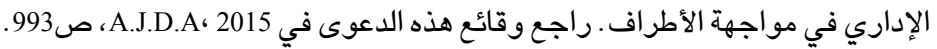

(211) C.E, 18-11-2011, Lige d'escrime du Languedoc - Roussillon, A.J.D.A, 2012, p.399.

(212) Hoepffner H., Op.cit., p.485.

(213) C.E, 15-4-1869, Section de saint - Louand.S.1899, 2, p.59.

(214) Le Chatellier G., Op.cit., n³5. Yolka PH., Op.cit., p.603. Cornu J., op.cit, p.44.

(215) C.E, 13-7-1967, Ecole privée de filles de pradelles, req.nº70777, R.339. C.E, 13-10-1967, Sté civile immobilière, R.P375. C.E, 2-2-1972, Min.de la santé publique et de la sécurité sociale, R.P106. C.A.A.Bordeau.6-11-2008, Centre hospitalier Saint - Nicoles de Blaye, A.J.D.A, 2009, P489, P489. Note Dreyfus J.D.

(216) C.E, 26-6-1974, Sté Maison des Isolants - France, R.P365. C.E, 31-3-1978, Eplé,R.p311. C.E, 28-11994, Sté Raymond Camus et Cie, R.P1041. D.1995, Somm, 125, obs.Terneyre.P. 
وفقاً لمضمون محدد، استناداً إلى صلح مبرم بينها وبين الغير، بحكم أن ذلك يخالف الم مقتضيات المشـروعية(217).

أما بالنسبة لسورية فقد بيَّنت الممارسـة العملية لمجلس الدولة السوري في إطار إجازة

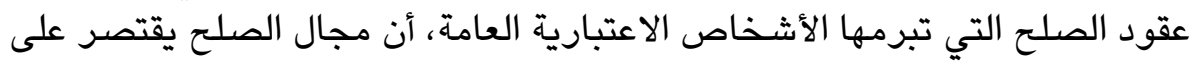

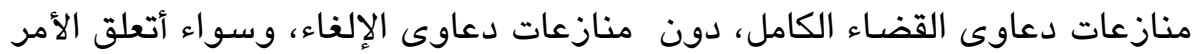

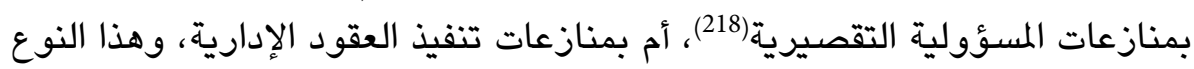

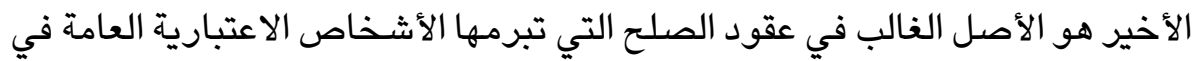
سورية(219). ولا يوجد في قطر أحكام مماثلة صريحة بالنسبة لحظر التنازل عن دعوى الإلغاء عن

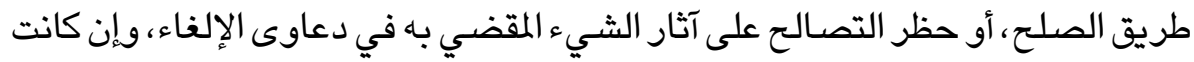

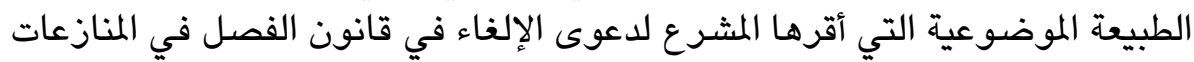
الإدارية تخدم هذه الفكرة في رأينا(220.

(217) C.E, 9-7-2015, Football club des girondins de Bordeaux, BJCP,n¹03, p.414.

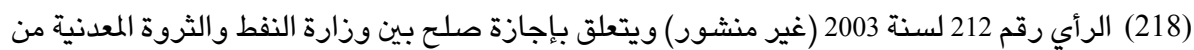

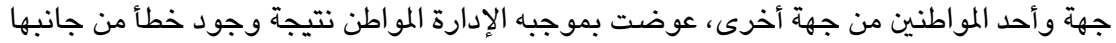

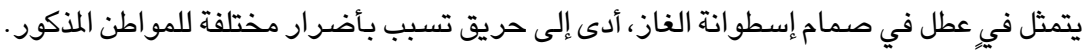

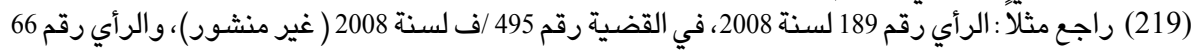

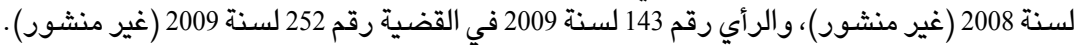
(220) راجع : المواد (3) و (4) و(11) من القانون رقم 7 لسنة 2007 المتضمن الفصل في المنازعات الإدارية. 


\section{الخاتمة:}

بعد استعراض الجوانب المختلفة للبحث وصلنا إلى جملة من النتائج والتوصيات نجملها

$$
\begin{aligned}
& \text { فيما يلي: } \\
& \text { أولاًا النتائجِ }
\end{aligned}
$$

1- إن التنازلات يجب أن تكون جوهرية Substantielle، ولا تكون كذلك إلا إذا تعلقت

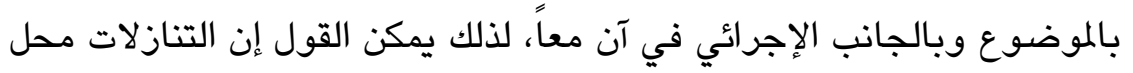

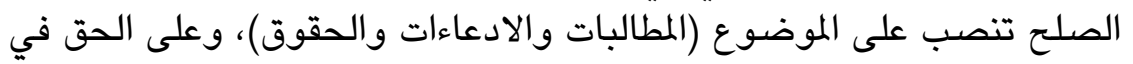
الدعوى Le droit d'agir في الوقت نفسعه.

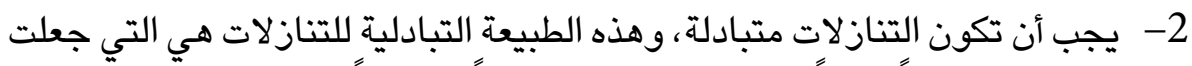

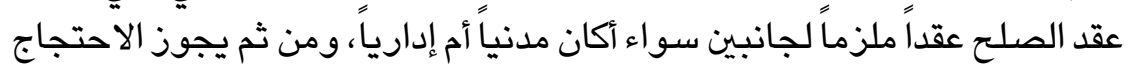

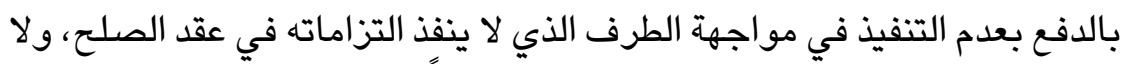

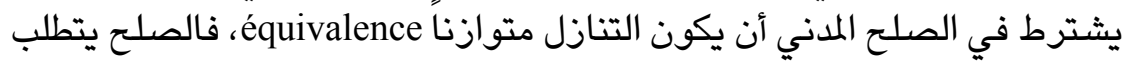

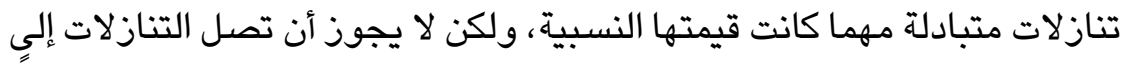

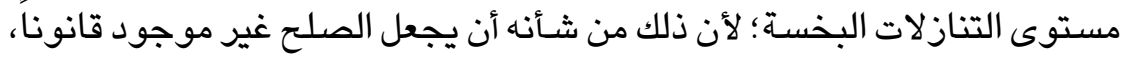
كما ذهبت محكمة النقض الفرنسية.

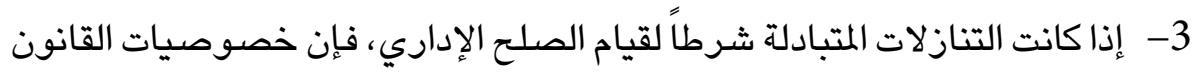

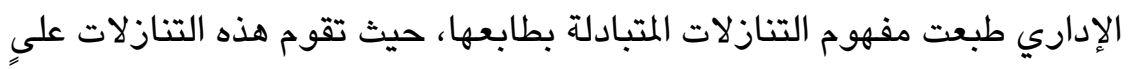

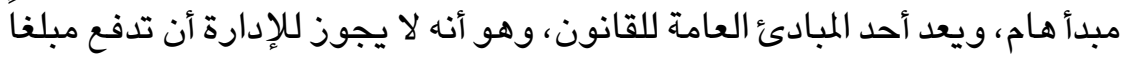

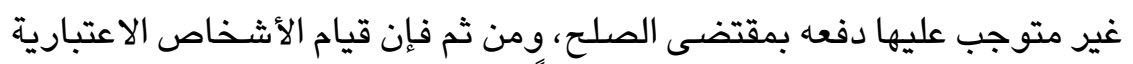

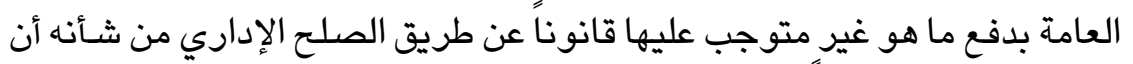

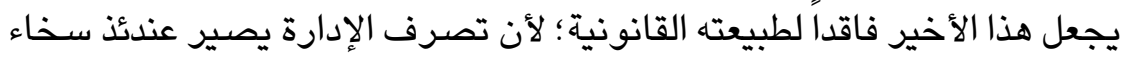
من شـأنه التفريط في المال العام . Libérlité

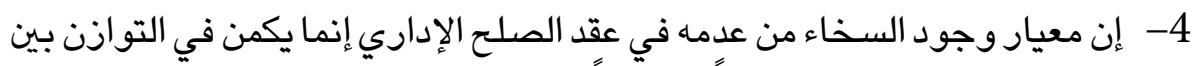

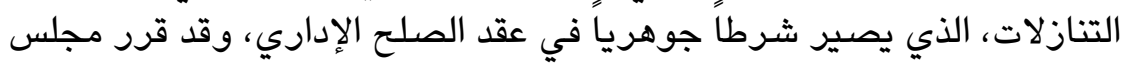

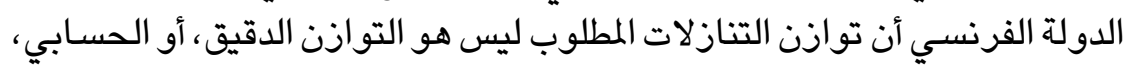

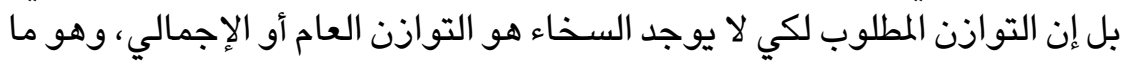
تأكد من خلال المنشورات الدورية الحديثة الصـادرة عن الوزير التوات الأول في فرنسا. 5- لم يعرف مجلس الدولة السوري رقابة السخاء، على نحو ما سار عليه مجلس 
الدولة الفرنسي، حيث لم يقم بالتطرق إلى التنازلات المتبادلة في سبيل تقييمها،

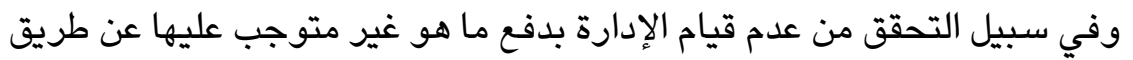

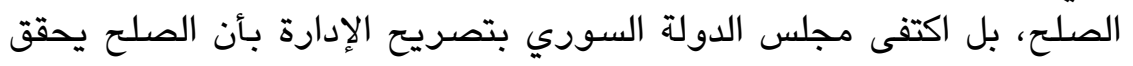

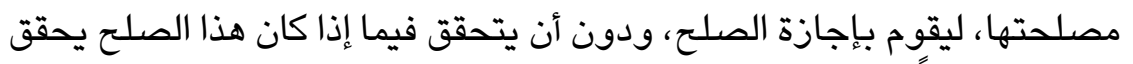
مصلحتها فعلاً.

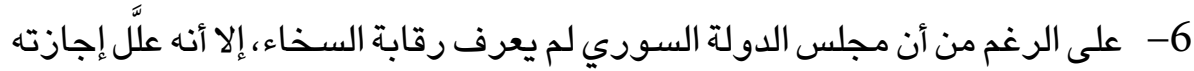

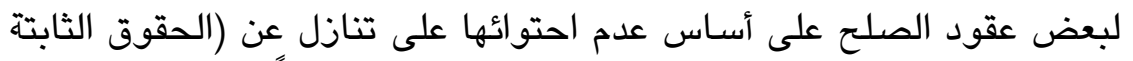

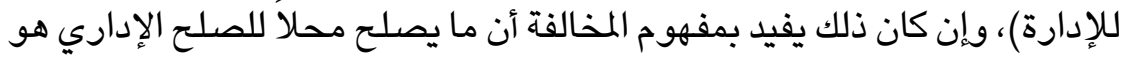

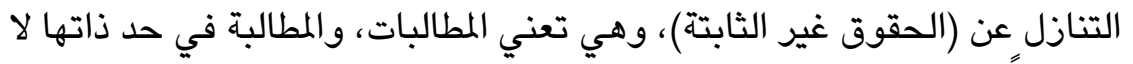

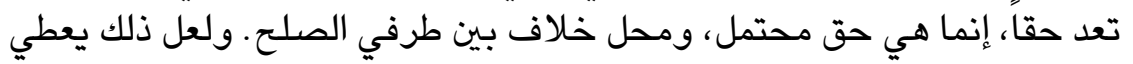

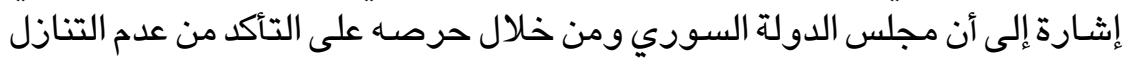

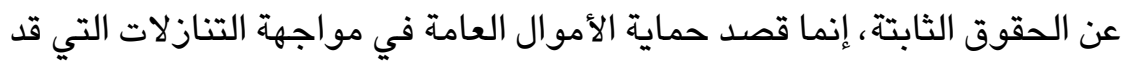

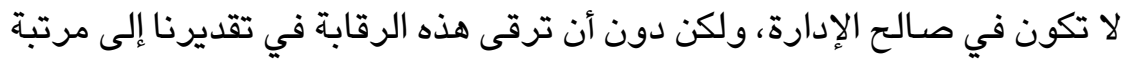

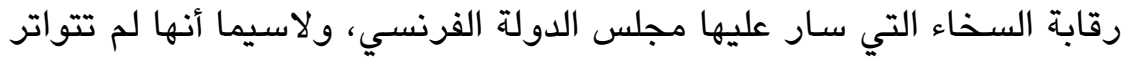

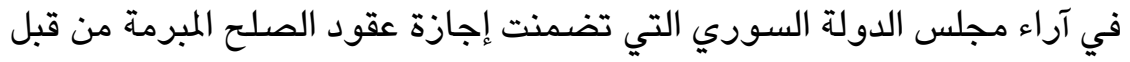
الأشخاص الاعتبارية العامة.

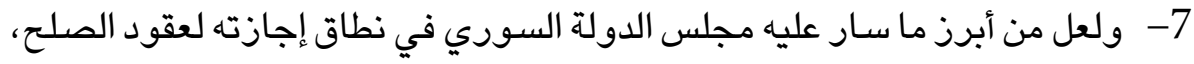

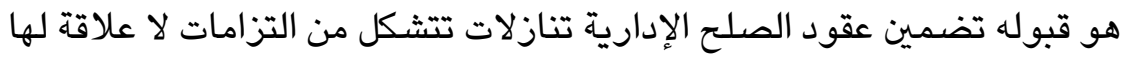

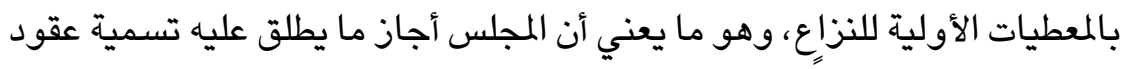

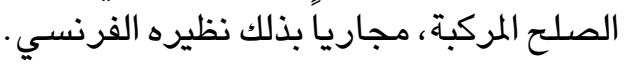

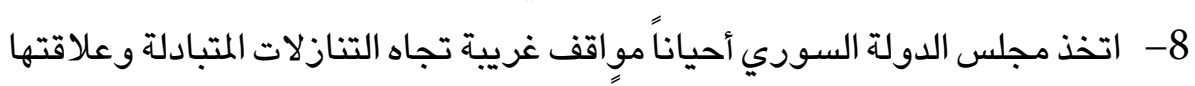

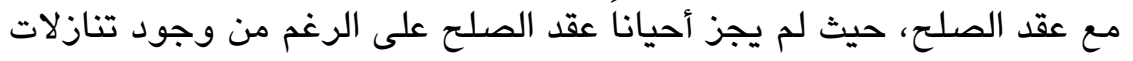

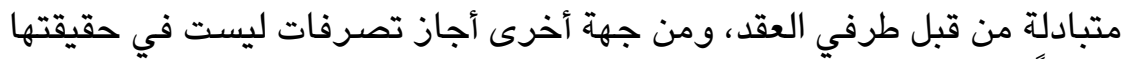

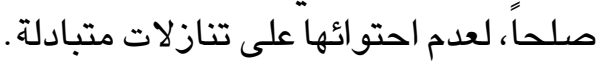

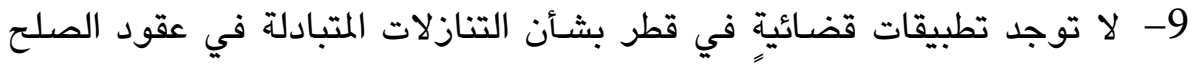

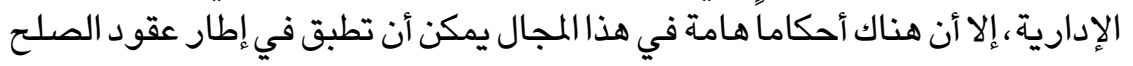

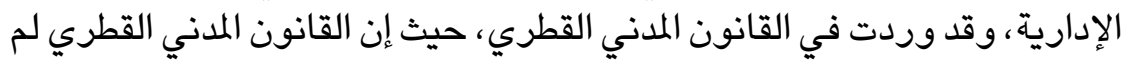

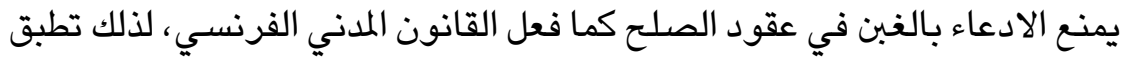

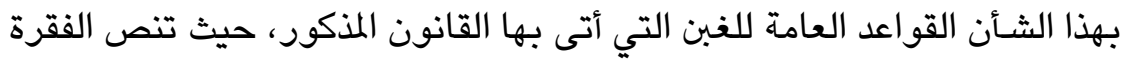




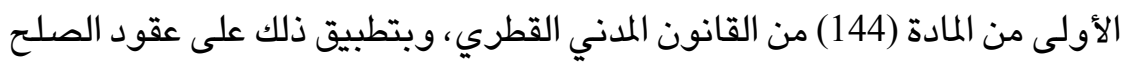

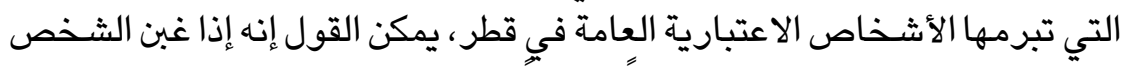

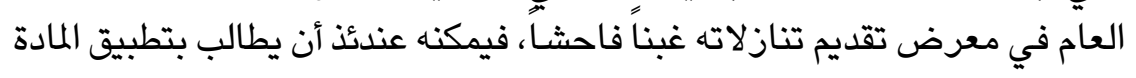

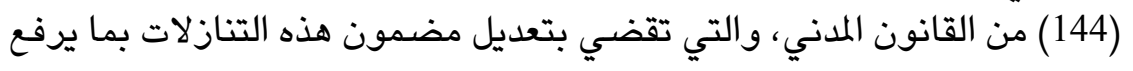

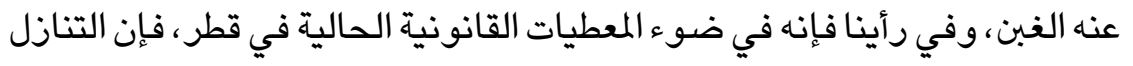

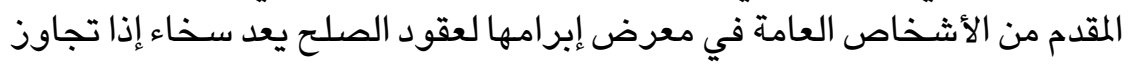

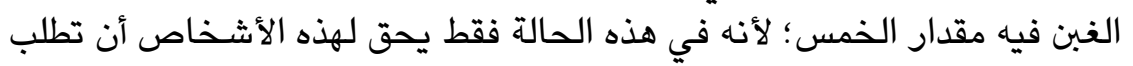
رفع الغبن.

10-إن الاختصاصات الإدارية تحدد بمقتضى النصوص القانونية؛ لذلك لا يمكن

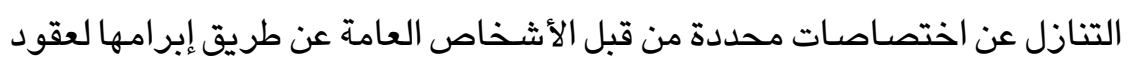

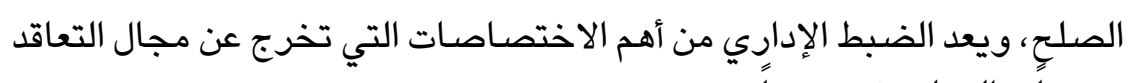
عموماً، والصلح خصو خصوصاً.

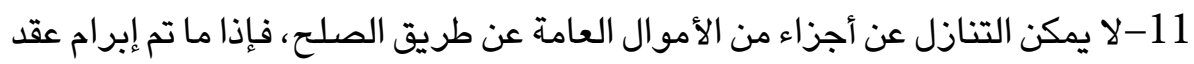

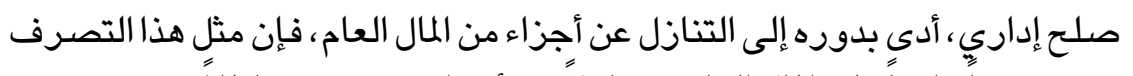

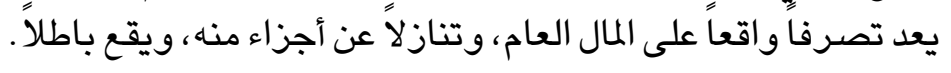

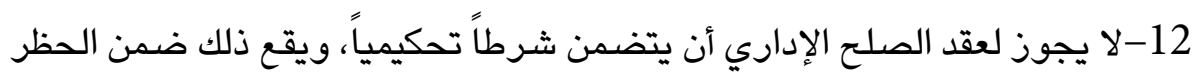

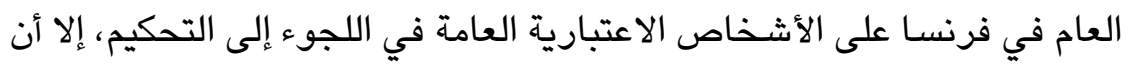

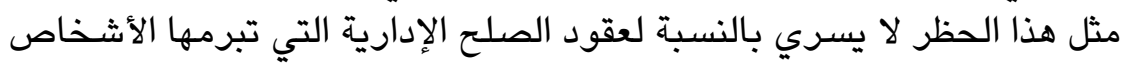

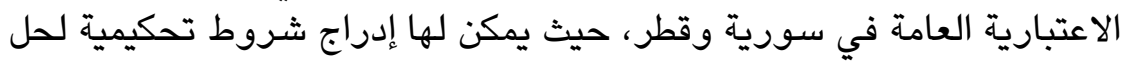

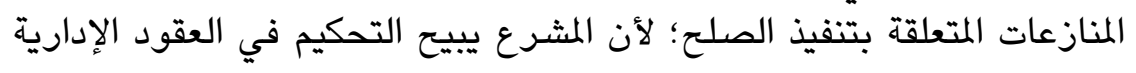
كأصل عام.

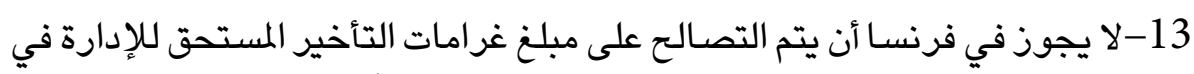

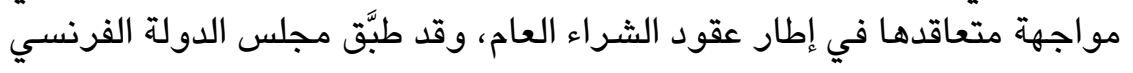

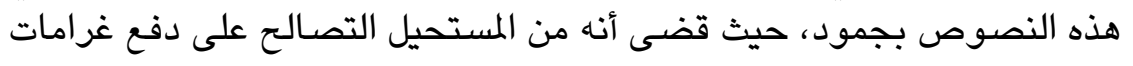

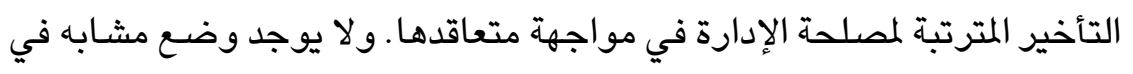

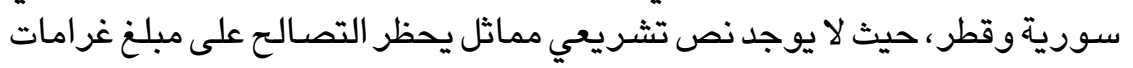

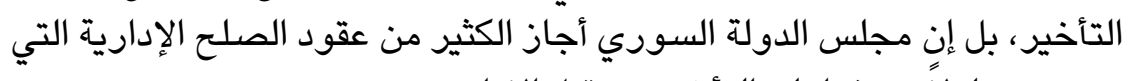
تتضمن تنازلاً عن غرامات التأخير من قبل الإدارة.

14-لا يمكن للإدارة أن تتصالح على المسائل المتعلقة بالمشروعية، فالصلح فكرة 
تتعارض مع فكرة المشـروعية؛ لأن الصلح لا يمكن أن يستخدم لأجل تغطية

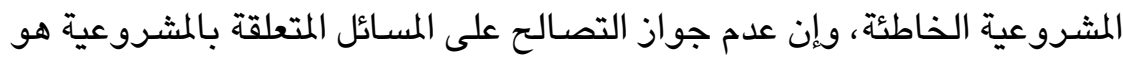
الذي يحظر في الوقت نفسه عدم جواز تنازل الفرد عن حقه في رفع دعوى الإلغاء صلحا في مواجهة قرار إداري غير مشـروع، وهو ما يعني عدم جواز تضمـين

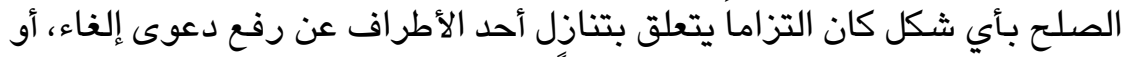

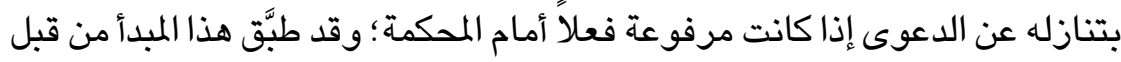

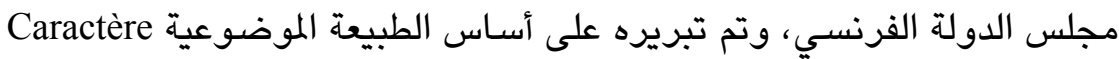
objectif

15-لايجوز للإدارة أن تتصالح على آثار الشيء المقضي به Les effets de la chose

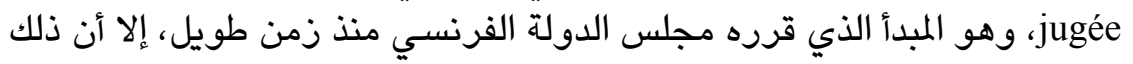

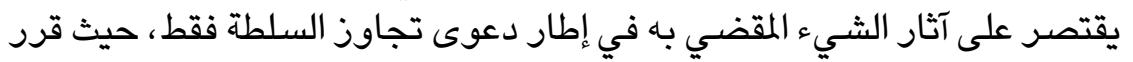

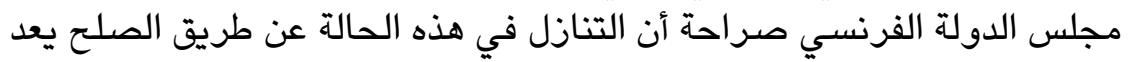

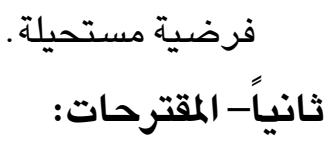

1- نقترح تعديل المادتين (517) من القانون المدني السوري و(573) من القانون المدني

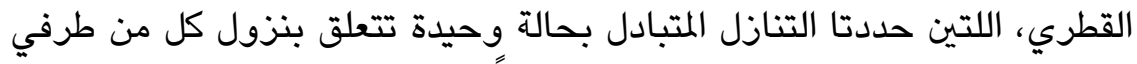

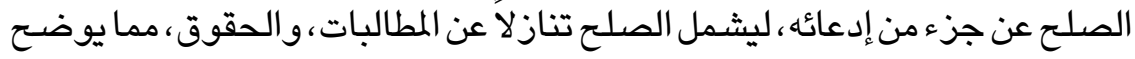

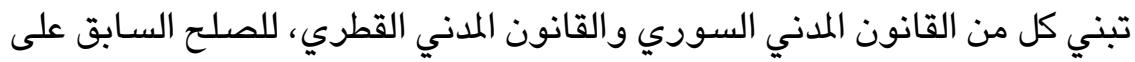

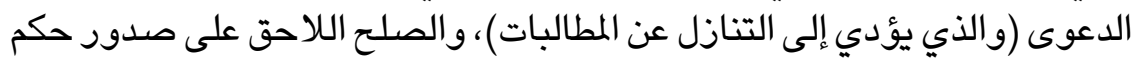

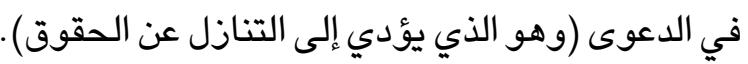

2- نقترح أن يحدد القضـاء الإداري في كل من قطر وسورية مفهوماً دقيقاً ومحدداً

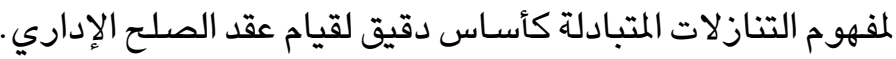
3- نقترح أن يتبنى القضـاء الإداري القطري مفهوم الصلّح المركب في إطار عقود الصلّح

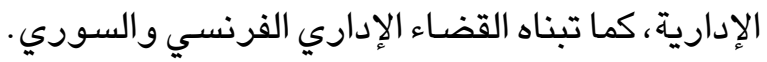
4- نقترح أن يتطرق مجلس الدولة السوري إلى جوهر التنازلات المتبادلة بين طرفي

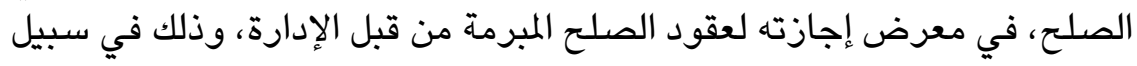

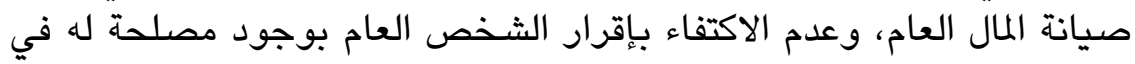

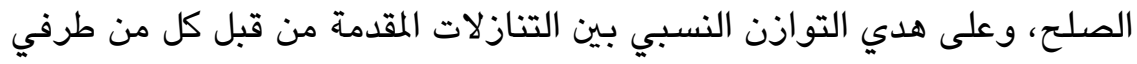

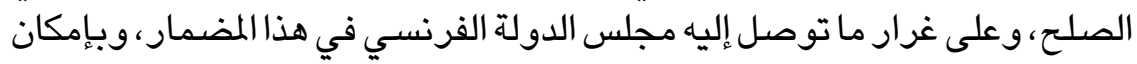


مجلس الدولة السوري أن يستند في سبيل تحقيق ذلك على اجتهاده غير المتواتر

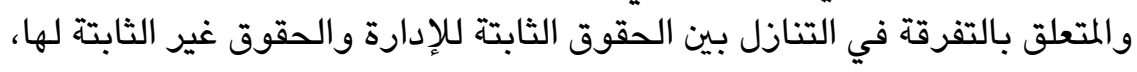

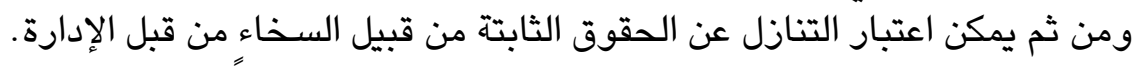

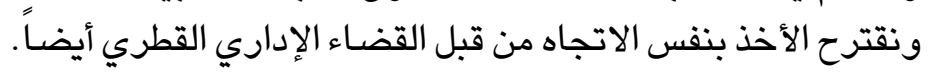

5- نقترح أن يأخذ مجلس الدولة السوري بمنهج دقيق في إطار تكييفه لعقود الصلح

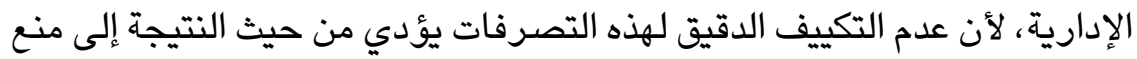

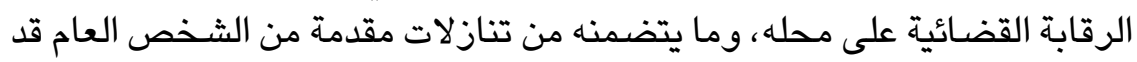

$$
\text { تنطوي بدورها على هدر للمال العام. }
$$

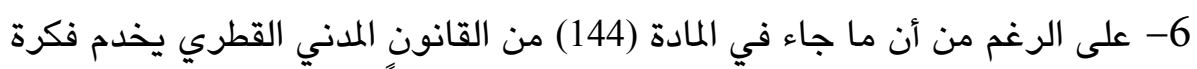

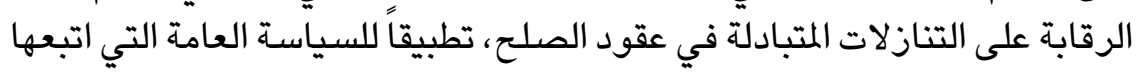

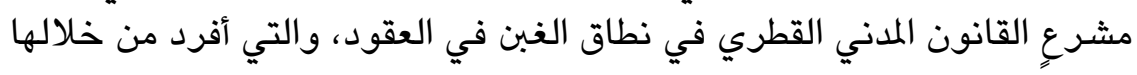

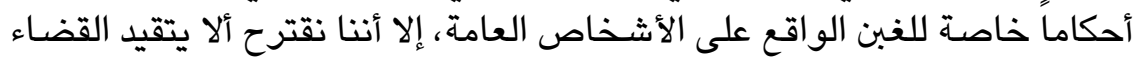

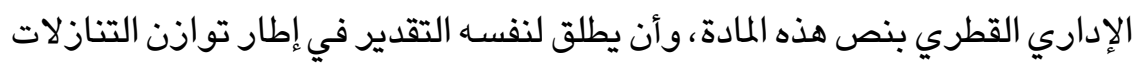

$$
\text { بين أطراف الصلح. }
$$

7- نقترح أن يتبنى المشرِع الفرنسي نصاً صريحاً يبيح التحكيم في المنازعات المتعلقة

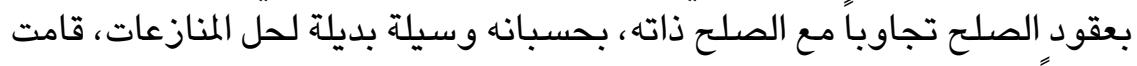
أساساً على منطق تفادي اللجوء إلى القضاء لهـاء.

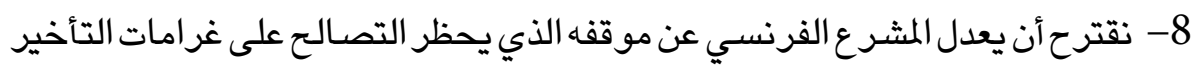

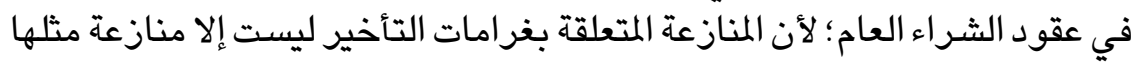

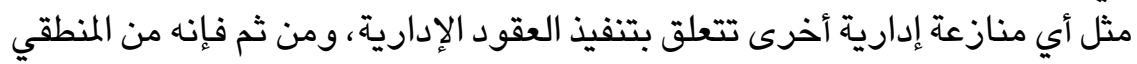
أن تخضع لحكمها في نطاق إباحة الصلح. 


\section{قائمة المراجح:

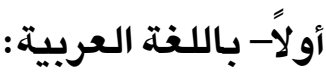

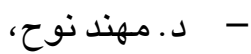

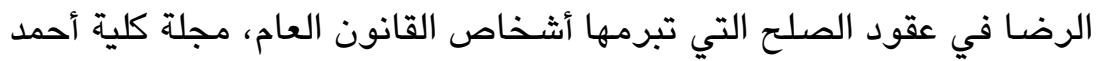

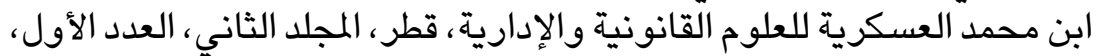

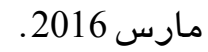

الإيجاب والقبول في العقد الإداري، ط2، منشورات الحلبي الحقوقية، بيروت، 2013.

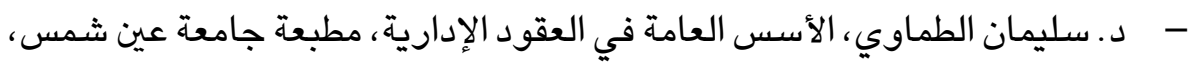

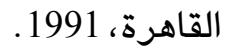

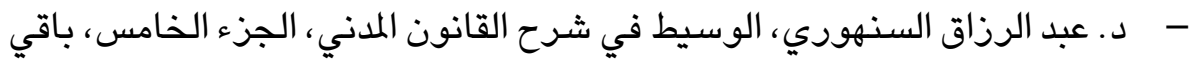

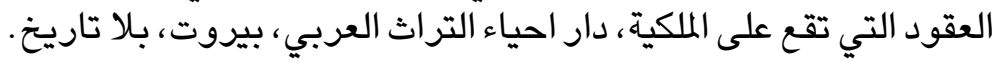

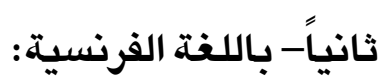

- Alhama F., Transaction et renonciation à l'exercice du recours pour excès de pouvoir, RFDA, 2017.

- Auby J.M.

- Bon.P -Auby.J.B-Terneyre.PH, Droit administratif des biens, Dalloz, Paris, 2011.

- La transaction en matière administrative, A.J.D.A, 1956.

- Braconnier S., Précis du droit des marchés publics, Le Moniteur, Paris, 2007.

- Chaaban R., L'article 2052 du code civil: erreur de rédaction ou erreur de droit? D, 2006.

- Chapus R., Droit du contentieux administratif, Montchrestien, Paris, 2008.

- Chatelier L.G., Transaction, Répertoire de contentieux administratif, Dalloz, 2010, (dernière mise à jour: mars 2014), nº28.

- Chauvel P.,Transaction, Répertoire de droit civil, septembre 2011 (actualité: mars 2014), nº41 et.s. 
- Chavrier G., Réflexions sur la transaction administrative, RFDA, 2000.

- Cornu J., La transaction en matière administrative, mémoire, Master recherche, Droit public approfondi, université, Paris II, 2007.

- Dacosta B, L'homologation d'une transaction en cassation, RFDA, 2008.

- Deliancourt S., Le contrôle du juge administratif sur le montant fixé par une convention de transaction pour des prestations réalisées hors contrat, AJDA, 2004.

- Dreyfus J.D.,Transaction et commande publique : les frontières avec le délit de favoritisme, AJ. Collectivités Territoriales 2012.

- Dyens S., Recourir à la transaction dans les collectivités territoriales, Droit Administratif n 5, Mai 2015, prat. 5.

- Florence N, Impossibilité de renoncer par transaction à exercer le recours pour accès de pouvoir, Droit admin, $\mathrm{n}^{\circ} 1$, Janvier, 2008, com8.

- Fourcade C., La transaction en droit du travail: quelle place pour la liberté contractuelle, R.D.S, 2007.

- Foussard D, L'arbitrage en droit administrative, A.J.D.A, R.arb, 1990.

- Gaudement Y, Traité de droit administratif, Droit administratif des biens, Paris, 2012.

- Godfrin PH- Degoffe M., Droit administratif des biens, Paris, 2012.

- Guettier Ch., Droit des contrats administratifs, P.U.F, Paris, 2011.

- Hoepffner H., Droit des contrats administratifs, Dalloz, Paris, 2016.

- Jarrosson CH., Les concessions réciproques dans la transaction, 1997.

- Lagard X., Transaction et ordre public, D, 2000, Chron.

- Linditch F, Une nouvelle circulaire pour encourager le recours à la transaction en matière de commande publique, J.C.P.A, n 42, 12 Octobre 2009.

- Lyon-Caen A., sur La Transaction en droit administratif, A.J.D.A, 1997.

- Melleray F., La répartition des compétences juridictionnelles en matière de transactions conclues par une personne publique, Droit Administratif, Novembre, 2007, $\mathrm{n}^{\circ}$ 11, comm. 156. 
- Merenne S, La transaction portant sur un recours pour excès de pouvoir, AJDA, 2015.

- Moreau J., Les matières contractuelles, AJDA, 1998.

- Noury A., Les modes alternatifs peuvent-ils prospérer dans le contentieux administratif? J.C.P.A, ${ }^{\circ}$ 30-34, 25 Juillet 2005, nº 10.

- Noury A, Les modes alternatives au règlement par les juridictions étatiques des litiges intéressant l'administration, C.R.A.P.S, Université lille 2, Paris, 2001.

- Rayssac R, La transaction en matière administrative, Thèse, université de Tour, France, 1999.

- $\quad$ Richer L., Droit des contrats administratifs, L.G. D. J, Paris, 2014.

- Richer L., Présence du contrat en la police administrative, A.J.D.A, 1999.

- Roux E., Panorama des différents modes alternatifs de règlement des litiges, AJ Collectivités Territoriales, 2012.

- Salvage F, Le caractère obligatoire d'une dépense née d'une transaction, RFDA, 2013.

- Sauveplane M., Le juge administratif et la déclaration de nullité d'une transaction, RFDA, 2004.

- Sirinelli J., La subjectivisation du recours pour excès de pouvoir, RFDA, 2016.

- Soler-Couteaux et Jean-Jacques Louis, Du bon usage de la transaction administrative dans les contrats publics, Contrats et Marchés publics $n^{\circ} 2$, Décembre 2000, chron. 2.

- Terneyre Ph, Désistement et transaction en matière de marché public: irrecevabilité de la demande en réparation des fautes commises dans les travaux de réfection, D, 1993.

- Yolka Ph, Traité de droit administratif, Les modes alternatifs de règlement des litiges administratifs, Dalloz, Paris, 2011, T2. 


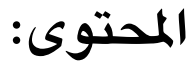

\begin{tabular}{|c|c|}
\hline الصفحة & 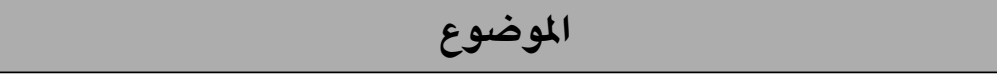 \\
\hline 199 & 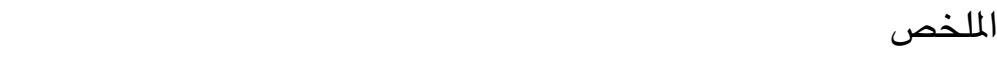 \\
\hline 201 & المقدمة \\
\hline 204 & المبحث الأول - المحل الموجود والممكن: فكرة التنازلات المتبادلة \\
\hline 204 & المطلب الأول- تطور مفهوم التنازلات المتبادلة في إطار عقد الصـلح الملني \\
\hline 210 & في ضطلب الثاني- تطور اجتهاد مفهوم التنازلات المتبادلة في عقود الصلح الإدارية \\
\hline 220 & المانوني في الثالث- التنازلات المتبادلة في عقود الصلّح الإدارية في النظام \\
\hline 227 & المتطلبحث الثاني_- المحل المشروع: نطاق محل عقد الصلّ الإداري وفقاً \\
\hline 227 & المطلب الأولٍ - المجالات التي لا يمكن التعاقد عليها أسـاسـاً لِيفوز التصـالح \\
\hline 228 & أولاً - الاختصساصـات الإدارية \\
\hline 228 & ثانياً- الأموال العامة \\
\hline 229 & ثالثاً عدم جواز أن يتضمن عقد الصلح الإداري شرطاً تحكيمياً \\
\hline 230 & رابعاً- عدم جواز الصلّح على غرامات التأخير \\
\hline 231 & خامسـاً- علم جواز التصـالح على المسؤولية العقدية \\
\hline 231 & المطلب الثاني - عدم جواز إبرام عقود الصلح الإدارية في مجال المشروعية \\
\hline 240 & 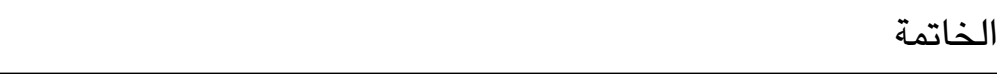 \\
\hline 245 & 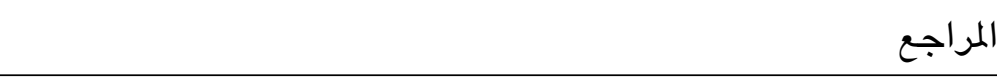 \\
\hline
\end{tabular}

